\title{
Római kori halomsírok Somogy megyében
}

\author{
CSIZMADIA GÁBOR ${ }^{1}$ és NÉMETH PÉTER GERGELY ${ }^{2}$ \\ ${ }^{1}$ Kaposvári Egyetem Idegen Nyelvi Igazgatóság, H-7400 Kaposvár, Guba Sándor u. 40., e-mail: csizmadia.gabor@ke.hu \\ ${ }^{2}$ Rippl-Rónai Megyei Hatókörű Városi Múzeum, H-7400 Kaposvár, Fő u. 10., e-mail: peter@smmi.hu
}

\begin{abstract}
Csizmadia, G. \& Németh, P. G.: Roman Tumuli in County Somogy.

Abstract: Besides introducing the Roman Age barrow cemeteries, this study also presents other burial locations of similar type with Prehistoric or uncertain dating, as well as the results of exploration of settlements near the Roman tumuli.
\end{abstract}

Keywords: Roman Age, Barrow, Tumulus, Cemetery, Settlement

\section{Bevezetés}

A római kori halmok kutatását 1993-ban kezdtük meg. Az adattári anyag összegyűjtése után terepbejárásokat folytattunk, elvégeztük a temetők geodéziai felmérést, majd az általunk római korinak vélt temetők szondázó ásatásait. Lehetőségünk csak két-két halom feltárására volt, 1996-ban Somogyaszalón, és 19971998-ban Somogyjádon. 2007-ben Somogyvár-Brézaerdőben három halom szondázó ásatást végeztük el. A római kori halmok regisztrálása mellett az őskori halmok feltérképezését is elvégeztük.

A halomsírkutatás megkezdését sürgetővé tette az, hogy az erdők kiirtásával és szántóterületté alakításával a temetők elpusztulnak, így ma már nem találjuk a Balatonszabadi-siómarosi, az orci és a jutai halomsírokat. Másrészt az építkezések jelentenek veszélyt, a Kaposvár határában lévő kisebb halomsírcsoport raktárépítkezések miatt tünt el, és így már a korát sem tudjuk megállapítani.

Elsőként a biztosan őskori, majd a bizonytalan keltezésü, illetve a ma már nem található halmokat ismertetjük. Negatív bejárások alatt azokat a helyeket ismertetjük, ahol a földrajzi névből kiindulva feltételezhettünk halmokat. A bejárásokat elsősorban a Somogy Megye Földrajzi Nevei (továbbiakban SMFN) alapján végeztük. ${ }^{1}$ Érdemes megemlíteni, hogy csak a Gombos, Halomi-dűlő illetve Kunhalom (Lengyeltóti) földrajzi név vonatkozott halmokra. Negatív eredményt hozott a Királyasztala, Nagyhalom, Kettőshalom, Hármashalom és Szabadi esetében a „Római buckák” bejárása is.

A továbbiakban azokról a halmokról teszünk részletesebben említést, melyekből római leletanyagunk van illetve a rendelkezésükre álló leírások alapján feltételezhető, hogy ebbe a korba tartoznak. A temetők közül az orci ma már elpusztult, a Nagyberki határában lévő kora vaskori halmok között római halmok is vannak. A

1 Somogy Megye Földrajzi Nevei. Budapest 1974. Az adatok idézése: először az oldalszám, majd a település száma, végül az adott településen belül a földrajzi elnevezés sorszáma. somogyvári, a somogyaszalói és a somogyjádi temetőket szondázó ásatások, míg az alsóbogátit a nagyszámú szórványlelet alapján keltezhetjük a római korba. Kísérletet tettünk az egykor Somogy, ma már Tolna megyéhez tartozó, Irregszemcse - csehipusztai római kori halmok megkeresésére is, de ez nem járt eredménnyel.

A tanulmány OTKA támogatással (T 026531) készült. A somogyjádi és a somogyaszalói ásatások Kaposvár Városának Tudományos Életért Alapítvány támogatásával történtek. A fotók, a rajzok és a térképek Nyári Zsolt munkája, melyet ezúton is köszönünk. A halmokról készült felvételekért M. Aradi Csillának és Nyári Zsoltnak tartozunk köszönettel. A felméréseket és a táblázatokat Csizmadia Gábor készítette. A tanulmány elkészítéséhez nyújtott támogatást Palágyi Sylviának ezúton is köszönjük.

\section{Öskori halmok}

\section{Lengyeltóti - Kunhalmok}

Lengyeltótiban, a Kossuth utca nyugati végénél lévő házak udvarán, két nagyméretű halom volt, az egyik feltárásánál kora vaskori leletek kerültek elő. ${ }^{2}$ 1981-ben a másik, szétdúlt halomnál, feltárásra nem volt lehetőség, csak megfigyelésekre korlátozódhatott a kutatás. ${ }^{3} \mathrm{~A}$ halmok helyétől nyugatra, az Alsó-Zsigmond- dűlőtől délre, öt halom (három nagyobb és két kisebb) azonosítása történt meg, melyek szintén a Hallstatt időszakba tartozhatnak. A meglévő halmok becsült méretei: Nagyobb halmok: magasság: 1 méter, átmérő: 10-12 méter, a kisebbeké: magasság: 0,60-0,80 méter, átmérő: 8 méter. ${ }^{4} \mathrm{~A}$ halomsírok a nagytatárvári kora vaskori földvár közelében helyezkednek el.

\section{Nagyberki - Szalacska}

A Nagyberki-szalacskai halmokról először Rómer Flóris adott értesítést. ${ }^{5}$ Melhárd Gyula a 19. század végén, római halmokat említ. ${ }^{6}$ Később Gallus Sándor, ${ }^{7}$

2 Sváby Aladár ásatása, 1930. Rippl-Rónai Múzeum Adattára (továbbiakban RRM A.) II/17/7. és Magyar Nemzeti Múzeum Régészeti adattára 21.I.I.). KÖH 43603. lelöhely.

3 Honti Szilvia leletmentése, 1981. RRM A. II/I7//12.

4 Németh Péter Gergely terepbejárása, 1996. és Honti Szilvia és Németh Péter Gergely terepbejárása, 1996. RRM. A. 859. KÖH 31046. lelöhely.

5 Rómer 1878, 115-121. és M. Kabay 1960, 46-49. KÖH 47877. és 56873. lelöhely.

6 Melhard 1900, 390.

7 M. Kabay 1960, 46-59 
majd Kemenczei Tibor őskori halmokat tárt fel. ${ }^{8} \mathrm{~A}$ koravaskori halmok nagyjából észak-déli irányban húzódnak, a szalacskai földvártól nyugatra.

A szalacskai földvártól délre, az erdőben, találjuk a második Szalacska környéki halomsírmezőt (Nagyberki-Csille). A halmok $\mathrm{K}-\mathrm{Ny}$-i irányban sorakoznak, egy halom a többitöl elkülönülve található. A halmok száma összesen 18. A halmok közül négyen jelenkori rablógödör látszik. ${ }^{9}$

\section{Mosdós - Deákdomb}

A szalacskai halomsírmezőtől nyugatra, a Nagyberki és Mosdós határát jelentő Tüskés-patak túlsó oldalán, kisebb halomsír csoport látható (XIII. t. 3.). ${ }^{10}$ Korábbi feltételezésünk szerint, ez az elkülönült csoportot, nagyon feltételesen, a római korba tartozónak véltük, de a kora vaskori keltezés elfogadhatóbbnak tünik.

A temető keleti részén nagyobb halom áll, magassága: $6,3 \mathrm{~m}$, átmérője: $48 \mathrm{~m}$. Ettől északnyugatra hasonló méretü kettős halom van (magasságuk: 5,5 és 3,6 m, átmérőjük 32,5 és 38,8 m). A többi kisebb halom nagyjából kelet-nyugat-i irányban sorakozik. A kisebb halmok átlagos magassága: 0,4 m, átmérőjük: $10 \mathrm{~m}$. Összesen jelenleg 12 halom látható, valószínűleg több kisebb halom a szántás miatt már eltűnt.

\section{Sávoly - Babócsa-halom}

Sávolyon magányos halom található, feltárására a Kis-Balaton program keretén belül került sor. ${ }^{11} \mathrm{~A}$ temetkezés ideje a késő bronzkorra, a késő halomsíros időszakra keltezhető. ${ }^{12}$

\section{Sávoly - Kápolna-puszta}

A babócsai halomtól délkeletre, mintegy 300 m-re, az erdőben,érintetlen halom található (becsült méretei: átmérő 25 méter, magasság 0,4 méter). ${ }^{13} \mathrm{~A}$ halmok közelsége miatt, a kápolna-pusztai is a késő bronzkori lehet. Szintén az erdőben, a két korábban említett halomtól keletre, újabb halmokat lehetett megfigyelni, az immáron nagyobb temető teljes felmérése még várat magára. ${ }^{14}$

\section{Tengőd - Bati-rétek}

Őskori halmokról történik említés, ${ }^{15}$ ma már nem találhatók meg, valószínüleg szántás során pusztultak el. ${ }^{16}$

\section{Tikos - Kusmit-domb}

Tikos község határában, a Sósi-erdő szélén, a 7-es úttól északra, nagyméretű halom látszik (becsült méretei: magasság 1 méter, átmérő 20-25 méter). A halom a Somogy Megye Földrajzi Nevei kiadványban is szerepel, a mesterséges dombot útépítés során alakították ki. ${ }^{17}$ Ugyanakkor Horváth László véleménye szerint nem lehet teljesen biztos az, hogy a halom jelenkori lenne, korábbi terepbejárása során őskori kerámiatöredékeket is talált a halom tetején. ${ }^{18}$

\section{Bizonytalan keltezésű halmok}

\section{Balatonszabadi - Siómaros-Sió-bozót}

A Sió-bozót déli részén, a szántásban, két halom volt. Egymástól való távolságuk kb. 40 m, átmérőjük kb. $4 \mathrm{~m}$, magasságuk kb. 0,5 m. A déli halom erősen körbeszántott, az északi halom déli részén több jelenkori beásás és rókalyuk volt. A halmok környékén őskori (bronzkori), római kori és középkori/újkori kerámiatöredékek kerültek elő. ${ }^{19}$ Szegvári Zoltán 2002. évi bejárása során, már a halmok elpusztítását regisztrálhatta. ${ }^{20}$

\section{Római kori szórványleletek a lelőhelyről:}

1. Edény töredékei

Nagyobb edény kihajló peremtöredéke és enyhén ívelt hastöredéke, belül jól látható korongolás nyomokkal. Porózus, világosbarna. $\mathrm{H}: 4,5 \mathrm{~cm}$. Sz: 2,8 $\mathrm{cm}$, illetve $\mathrm{H}: 4,7 \mathrm{~cm}$. Sz: 3,4 cm. Fv: 0,7 cm. Ltsz: R.98.13.1. (I. t. 9.) ${ }^{21}$

2. Edénytöredék

Enyhén ívelt, vékonyfalú, fehér, kívül narancssárga festéssel. H: 2,6 cm. Sz: 1,8 cm. Fv: 0,3 cm. Ltsz: R.98.13.2.

3. Peremtöredék

Vízszintesen kihúzott peremtöredék, belül árkolás fut körbe. Keményre kiégetett, kaviccsal soványított, szürke. H: 1,1 cm. Sz: 1,7 cm. Fv: 0,3 cm. Ltsz: R.98.13.3.

4. Oldaltöredékek

Különböző edények enyhén ívelt, szürke színű töredékei (3 db). H: $5 \mathrm{~cm}$. Sz: 3,2 cm. Fv: 0,9 cm, H: $4,3 \mathrm{~cm}$. Sz: 3,9 cm. Fv: $1 \mathrm{~cm}$ és H: $5,2 \mathrm{~cm}$. Sz: 3,6 cm. Fv: 0,7 cm. Ltsz: R.98.13.4.

8 Kemenczei 1974., 1975. és 1976.

9 Németh Péter Gergely terepbejárása, 1998. RRM A. 1233. KÖH 32372. lelöhely.

10 Vörös János (Somogy Megyei Földhivatal bejelentése RRM A. IV/45/4. és Csizmadia Gábor-Németh Péter Gergely terepbejárása 1993. RRM A. 530. KÖH 47776. lelöhely.

11 Honti Szilvia és Németh Péter Gergely ásatása, 1993-1995.

12 Honti 1996

13 Kiss Viktória-Németh Péter Gergely terepbejárása 1999. VörsBattyáni disznólegelő ásatási napló (1999. 240. old.). RRM A. 1382. A halomsírra Németh József erdőfelügyelő hívta fel a figyelmünket, melyet ezúton is köszönünk. KÖH 43050. lelöhely.

14 Az újabb halmokra is Németh József hívta fel a figyelmünket, melyet ezúton is köszönünk.

15 RRM A. I/16/2.

16 Németh Péter Gergely terepbejárása, 1999. RRM A. 1381. KÖH 30400. lelöhely.

17 SMFN 100, 20/23. KÖH 32361. lelöhely.

18 M. Aradi Csilla - Honti Szilvia-Horváth László-Németh Péter Gergely terepbejárása 1989. és M. Aradi Csilla-Honti Szilvia-Németh Péter Gergely helyszínelése 1997. RRM A: 2066. Horváth Lászlónak szíves szóbeli tájékoztatását ezúton is köszönjük.

19 Németh Péter Gergely terepbejárása, 1994. RRM A. 609. Ltsz R.98.13.1-4. KÖH 32326. lelőhely. A tanulmányban szereplő őskori leletek meghatározását Honti Szilviának ezúton is köszönjük.

20 Szegvári 2003, 13. és 2. kép. Szegvári Zoltán tájékoztatását ezúton is köszönjük. Köszönettel tartozunk továbbá azért, hogy szakdolgozatába betekinthettünk

21 A publikációban használt rövidítések: H: hosszúság, Sz: szélesség, Szá: száiátmérő, Fá: fenékátmérő, Á: átmérő, M: magasság, V: vastagság, Fv: falvastagság, Tör: töredék, Átl: átlagos, Ltsz: leltári szám. 


\section{Balatonszabadi-Alsó - Páskum}

Az M7-autóúttól északra, a Siófok-Kelet bekötőúttól nyugatra, a Sóstó és Madarasi-dülő között, két nagyobb halom látható, egymástól való távolságuk kb. 50 $\mathrm{m}$, magasságuk kb. $1 \mathrm{~m}$, átmérőjük kb. $6 \mathrm{~m}$. Mindkét halmon villanyoszlop áll. Egy harmadik, kisebb kiemelkedés esetleg szintén halom volt, de valószínübb, hogy inkább a bekötőút építésének maradványa. A halmok környékén végzett terepbejárás során régészeti leletet nem sikerült gyüjteni. ${ }^{22}$

Balatonszabadi környékéröl Kuzsinszki Bálint említ egy halmot, ${ }^{23}$ Lázár Jenő pedig Siómarosról Ha C időszakba tartozó tumulust. ${ }^{24}$ Ugyancsak Balatonszabadiban, a Pusztatoronyi-dülő környékéről említés történik halomsír csoportról, ${ }^{25} \mathrm{de}$ egyértelmüen egyik lelöhelyet sem lehet azonosítani az irodalomban szereplő halmokkal és nyitott a halmok korszakba sorolása is.

\section{Balatonszabadi - Sashalom}

Balatonszabadi-Siómaroson, a temetőben lévő Sashalmot vagy Basahalmot Laczkó Dezső említi, nem eldöntve, hogy halomsírt látott, vagy mesterséges dombot. ${ }^{26}$ Egy 1994-es ${ }^{27}$ és egy 2004 . évi helyszínelés, ${ }^{28} a$ sürü növényzet miatt, nem volt eredményes. 2009ben, a kitisztított területen, jól meg lehetett figyelni egy nagyobb és egy kisebb dombot. ${ }^{29} \mathrm{~A}$ kisebbik nem lehet halomsír, inkább területrendezés nyoma lehet, a nagyobbik, méreteinél fogva teszi kétségessé, hogy halmos temetkezést rejtene. Egyik terepbejárás során sem került elő leletanyag, a Sashalomtól északra római kori temetőre utaló adatokat ismerünk. ${ }^{30}$

\section{Böhönye - Székula (Cifra-major)}

Nagyobb temetőre utaló adat Böhönyéről származik, Rómer Flóris 50 halomból álló temetőt említ. ${ }^{31} \mathrm{~A}$ halmok valószínüleg erdőtelepítés során elpusztultak, koruk meghatározhatatlan. ${ }^{32}$

22 Németh Péter Gergely terepbejárása, 1994. RRM A. 609. KÖH 19400-19401. (Alsó-Páskun I. és II.) lelőhely.

23 Kuzsinszki 1920, 207. KÖH 19411. lelöhely. Kuzsinszki szerint a halom a Balaton partjától beljebb, a Madarasi-dűlőben található, magassága 3,5 méter, átmérője „körülbelül 70 lépés”. Mivel a Siófok-Madarasi-dülő és az Alsó-Páskum egymással szomszédos dülők, esetleg a ma is látható halmokra vonatkozik, de Kuzsinszki csak egy halmot említ.

24 Lázár 1956, 1. ábra. A szövegben a szerző nem tesz említést a halomról, csak a térképen szerepel.

25 Régészeti Kataszter, Veszprém. I. k. 87. KÖH 19394. lelöhely.

26 Laczkó 1912, 15. SMFN 137, 32/54. KÖH 19395. lelőhely.

27 Németh Péter Gergely terepbejárása. RRM A. 609.

28 Marton Tibor terepbejárása. RRM A. 4576. és 4579.

29 Honti Szilvia, Molnár István és Németh Péter Gergely terepbejárása. RRM A. 2636. és 3447.

30 Laczkó 1912, 15. 1964-ben és 1977-ben is kerültek elő római kor temetöre utaló adatok RRM A. 827. és 833. KÖH 19396. lelőhely.

31 Rómer 1878, 157.

32 Németh Péter Gergely terepbejárása 1994. RRM A. 607. és 629. Molnár József, egykori böhönyei polgármester tájékoztatása szerint, melyet ezúton is köszönünk, a tumulusok elpusztultak. Molnár József emléke szerint a halmok $40-50 \mathrm{~cm}$ magasak voltak.

\section{Böhönye - Csöpröndi erdő}

Böhönyétöl keletre, Terebezd-pusztától délre, a Csöpröndi- erdőben, egy 1959-es feljegyzés szerint, 15-20 db lapos, 1 m-nél alacsonyabb, 8-10 m átmérőjü, „hullámos”, kettős sorban húzódó halomsíros temető található. Két halomba a háború alatt bunkert ástak. ${ }^{33} \mathrm{~A}$ 2016. évi bejárás során a halmokat nem lehetett megközelíteni. A helyszínen lévő SEFAG-erdészet munkatársa nem emlékezett halmokra, csak világháborús árkokra. Ugyanakkor Várvizy Péter elmondása szerint, amikor 6 évvel ezelőtt a területen járt, 8-10, nagyjából egy sorban lévő, kb. 80-100 cm magas halmot látott. ${ }^{34}$

\section{Gölle és Somogyszil határa (Alsó-Major)}

A két község határán, két erősen szétszántott halom található. A keleti, épebb halom méretei: átmérő kb. $15-20 \mathrm{~m}$, magassága kb. $50-70 \mathrm{~cm}$. Mindkét halmon több mészkőtöredéket találtunk, ezért valószínű, hogy a szántás a halmok kőkamráját is elérte. ${ }^{35}$ Ásatás nélkül nem meghatározható a halmok kora. A halmoktól északra (már Somogyszil területén), a Göllei-pataktól keletre, nagy területen elszórva, őskori és római kori kerámiatöredékek kerültek elő. ${ }^{36}$

\section{A keleti halom felszínéröl:}

1. Dörzstál töredéke

Dörzstál aljtöredéke. Kopott, világosbarna. H: 10,5 cm. Sz: 7,7 cm. Fv: 1,2 cm. Ltsz: R.2004.6.1. (XI. t. 5.).

2. Dörzstál töredéke

Dörzstál aljtöredéke. Kopott, narancssárga. H: 7,6 cm. Sz: 5,2 cm. Fv: 1,2 cm. Ltsz: R.2004.6.2. (XI. t. 4.).

3. Dörzstál töredékei

Dörzstál oldaltöredékei. Világosbarna, belül zöld mázzal. H: $4,3 \mathrm{~cm}$. Sz: $2,3 \mathrm{~cm}$. Fv: $0,8 \mathrm{~cm}$, és $\mathrm{H}: 5$ cm. Sz: 1,4 cm. Fv: 0,7 cm. Ltsz: R.2004.6.3.

4. Táltöredék

Tál szürke színű oldaltöredéke, erősen kiemelkedő bordával. H: 4,8 cm. Sz: $2,5 \mathrm{~cm}$. Fv: 0,6 cm. Ltsz: R.2004.6.7.

5. Edény töredékei

Valószínűleg egy edény oldaltöredékei (6 db). Porózus, világosbarna. Átl. Fv: $0,5 \mathrm{~cm}$. Ltsz: R.2004.6.4.

6. Peremtöredék

Kihajló, kopott, porózus, világosszürke színű töredék. H: $4 \mathrm{~cm}$. Sz: $1,8 \mathrm{~cm}$. Fv: $0,6 \mathrm{~cm}$. Ltsz: R.2004.6.5.

7. Oldaltöredékek

Különböző edények seprüdíszes, szürke színű oldaltöredékei. H: $5,2 \mathrm{~cm}$. Sz: $5,2 \mathrm{~cm}$. Fv: 0,9 cm, és H: 5 cm. Sz: 3,5 cm. Fv: 0,8 cm. Ltsz: R.2004.6.6.

33 RRM A. 6631. Böhönye - Csöpröndi erdő I. lelöhely. KÖH 19677. lelöhely.

34 Hajdú Ádám-Németh Péter Gergely terepbejárása 2016. április 19. Várvizy Péter (Somogyszob, Petőfi u. 40.) tájékoztatását ezúton is köszönjük.

35 Németh Péter Gergely terepbejárása 1998. RRM A. 1234. KÖH 20578. lelöhely. A halmokra Berta Gyula (Kaposvár, Pete u. 8.) hívta fel a figyelmünket, melyet ezúton is köszönünk.

36 Berta Gyula véleménye szerint a lelöhely a patak túloldalán is folytatódik, ezt a részt azonban nem tudtuk bejárni. RRM A. 1234 
8. Fültöredék

Hármas tagolású, szürke-barna színü töredék. H: 5,6 cm. Sz: 2,9 cm. Fv: 1,3 cm. Ltsz: R.2004.6.8.

9. Aljtöredék

Világosszürke, finoman iszapolt aljtöredék. H: 5,1 cm. Sz: 4,3 cm. Fv: 0,9 cm. Ltsz: R.2004.6.9.

A domb felső része:

10. Pohártöredék

Kihajló peremü, keményre kiégetett, csillámos felszínű, szürke. H: 4,2 cm. Sz: 5,8 cm. Fv: 0,4 cm. Ltsz: R.2004.6.10. (XI. t. 2.).

11. Oldaltöredék

Porózus, világosbarna, narancssárga festés nyomaival. H: 5,9 cm. Sz: $3,4 \mathrm{~cm}$. Fv: $0,7 \mathrm{~cm}$. Ltsz: R.2004.6.11.

\section{A patak keleti partján:}

\section{Táltöredék}

Kihajló peremü, a vállon törés, alatta bepecsételt díszítés. Barna színű, barna festéssel, $\mathrm{H}: 5 \mathrm{~cm}$. Sz: 7 cm. Fv: 0,6 cm. Ltsz: R.2004.6.12. (XI. t. 1.).

13. Táltöredék

Behajló peremű, porózus, barna, narancssárga festés nyomaival. $\mathrm{H}: 3,5 \mathrm{~cm}$. Sz: $3 \mathrm{~cm}$. Fv: 0,6 cm. Ltsz: R.2004.6.13.

14. Oldaltöredék

Árkolással és sávos narancssárga festéssel díszített, belül világosbarna. $\mathrm{H}: 5 \mathrm{~cm}$. Sz: $2,9 \mathrm{~cm}$. Fv: 0,6 cm. Ltsz: R.2004.6.14. (XI. t. 3.).

15. Táltöredék

Kihajló peremű, enyhén ívelt falú, árkolt, porózus, szürke. H: 4,2 cm. Sz: 3,1 cm. Fv: 0,6 cm. Ltsz: R.2004.6.15.

16. Peremtöredék

Kihajló peremü, keményre kiégetett, csillámos felszínü, szürke. H: 4,2 cm. Sz: $5,8 \mathrm{~cm}$. Fv: 0,4 cm. Ltsz: R.2004.6.10.

17. Peremtöredék

Kihajló, profilált peremtöredék. Keményre kiégetett, szürke. H: 2,7 cm. Sz: $2 \mathrm{~cm}$. Fv: 0,6 cm. Ltsz: R.2004.6.17.

Az Alsó-majori lelőhelytől távolabb, mintegy 2 kmre, nagykiterjedésű római kori lelőhely található (GöllePótlék). Sok tégla- és kőtöredék alapján esetleg épület is lehetett itt. ${ }^{37}$

\section{Gyékényes - Lankóczi-erdó}

Az avar kori kohóteleptől nyugatra, kettő, a kohóteleptöl délkeletre több, kavicsból emelt halom látható. A halmok becsült száma 5-10, becsült méreteik: Magasság: 0,5 méter, átmérő 5-10 méter. $^{38}$

37 RRM A. 1234. Erre a lelöhelyre is Berta Gyula hívta fel a figyelmünket, melyet ezúton is köszönünk. KÖH 20576. lelöhely.

38 Költő László terepbejárása 1998. RRM. A. 1197. KÖH 32373. lelőhely.

\section{Juta - Gombosi-erdö}

Juta község déli végénél, a kaposújlaki határban lévő Gombosi-erdőben, kisebb halomsírcsoport állt Az erdőt 1944-ben kiirtották és a szántás során megkezdődött a halmok pusztulása. 1945-1946-ban két halmot elhordtak és egyet félig elbontottak. Az egyik halomból aranyfibula (?), a másikból bronzfibula került elő, több edény társaságában. A halmok közepén megfigyelhető volt a máglya nyoma (esetleg hamvasztásos sír maradványai (?). A harmadik halomban bronzdarabok (lószerszámdíszek?) voltak. Ugyanitt, a máglya mellett, szabályos, négyzet alakú, sötét színű földdel telített beásás volt, ezt nem bontották ki. ${ }^{39}$ A leletek a kaposvári múzeumba nem kerültek be.

$\mathrm{Az}$ 1960-as években még jól látszott 20 halom. A tumulusok becsült mérete: átmérő 8-10 m, magasság 60-100 cm volt. Római kori és középkori kerámiatöredékek kerültek elő terepbejárás során. ${ }^{40} \mathrm{~A}$ halmok elhelyezkedéséről vázlatrajz készült (XIII. t. 2.). Ez alapján a halomsírmező szabálytalan szerkezetü, tájolása nagyjából észak-déli irányú. ${ }^{41}$

Helyszínelésünk alkalmával már csak két, gyengén kiemelkedő részt láttunk, esetleg az időközben elszántott halmok maradványait. A területen őskori, római kori és középkori kerámiatöredékeket találtunk. ${ }^{42}$ Egy évvel későbbi terepbejárás során már csak egy határozatlan kiemelkedés látszott, hamumaradvánnyal. ${ }^{43}$

A terepbejárások alapján nem lehetett eldönteni, hogy őskori vagy római kori halmok voltak az erdőben. A leírás és a temető szerkezete inkább az őskori keltezést erősíti.

\section{Római kori szórványleletek a lelöhelyröl:}

1. Fazék peremtöredéke Kihajló peremü töredék, a perem alatt árkolás fut körbe, sötétszürke. H: $6 \mathrm{~cm}$. Sz: 1,7 cm. Fv: 0,4 cm. Lsz: R.98.15.4. (I. t. 10.)

2. Peremtöredékek

Különböző edények kihajló peremű, szürke színű töredékei. H: 3,8 cm. Sz: 2,9 cm, illetve H: $2 \mathrm{~cm}$. Sz: $1,7 \mathrm{~cm}$. Fv: 0,5 cm. Ltsz: R.98.15.1.

3. Oldaltöredék

Enyhén ívelt, porózus, okkersárga, narancssárga festés nyomaival. H: 4,4 cm. Sz: 3,4 cm. Fv: 0,5 cm. Ltsz: R.98.15.2.

4. Oldaltöredékek

Különböző edények seprüdíszes, szürke színü töredékei. H: 4,4 cm. Sz: 3,4 cm. Fv: 0,8 cm, ill. H: 7,5 cm. Sz: $5,1 \mathrm{~cm}$. Fv: $0,7 \mathrm{~cm}$. Ltsz: R.98.15.3. és 5 .

\footnotetext{
39 RRM A. IV/34/2. KÖH 26584. lelöhely.

40 RRM A. IV/25/4

41 RRM A. IV/25/5.

42 Csizmadia Gábor és Németh Péter Gergely terepbejárása 1993. A halomsírmező egykori helyét Dobai József (Juta, Szabadság u. 32.) mutatta meg, amelyet ezúton is köszönünk. RRM A. 603. Dobai József az általa korábban látott halmok magasságát $80 \mathrm{~cm}$ re becsülte.
}

43 Németh Péter Gergely terepbejárása 1994. RRM A. 598. 


\section{Kaposvár - Gombos (Papsára)}

Kaposvár északnyugati részén, 1943-ban, 3-4 halomsírt lehetett megfigyelni. Az 1990-ben végzett terepbejárás eredménytelen volt. A halmok valószínüleg az itt lévő raktárak építése során pusztultak el. ${ }^{44}$

\section{Lábod - Csókhegyi-düló}

A Vaslétai-erdőtől délre, a Nagyatádra vezető müúttól északra, a szántás szélén, kisebb domb van, magassági ponttal, mely esetleg halomsír lehet. A domb átmérője kb. $20 \mathrm{~m}$, magassága kb. 1,8 m. ${ }^{45}$

\section{Libickozma - a település déli vége}

Kisebb halomsírmező (12 halom) található a templom és a Malom-árok között, kelet-nyugati irányban, két sorban.$^{46} \mathrm{~A}$ két sor között nagyobb, üres rész van. A templom mellett két nagyobb halom van, ezektöl nyugatra egy újabb nagyobb. Ettől délre a domb szélén, egy bizonytalan kiemelkedés található. Egy csaknem teljesen kirabolt és elpusztított halmot délröl egy árok szegélyez, ettől délre egy kisebb halom van. A domb szélén két bizonytalan kiemelkedés van. A birkalegelöre vezető földúttól délre, három, észak-déli irányban sorakozó földsír látható. A halmok átlagos átmérője kb. $8 \mathrm{~m}$, magasságuk $30-50 \mathrm{~cm}$. A halmok a temető kelet-nyugati irányú szerkezete, a halmok mérete és római kori lelöhelyek közelsége (Gerberica, Gerberica délnyugat és esetleg a Temető melletti rész ${ }^{47}$ miatt, esetleg római koriak.

\section{Marcali - Halom}

A Marcalitól keletre lévő, magányos halmot, még 1879-ben, Melhárd Gyula tárta fel, és leírása alapján nem eldönthető a halom keltezése. ${ }^{48}$

\section{Öreglak - Szent-kúti-dülö}

Az Öreglakról a régi malomhoz (Cifra malom) vezető út és az attól keletre lévő Malomárok között, mintegy húsz halom látható. ${ }^{49} \mathrm{~A}$ halmok kb. 700 méter hosszúságban, észak-déli irányban találhatók, eredetileg számuk jóval nagyobb lehetett. Mindegyik halmon nagyon sok elaprózódott mészkőtöredék található. A halmok becsült mérete: magasság 0,5 méter, átmérő $15-20$ méter. A lelöhely közepén, a Malomárokba folyó kisebb vízfolyás északi oldalán, késő bronzkori vagy kora vaskori és kelta kerámiatöredékek mellett római telepre

44 Németh Péter Gergely terepbejárása 1990. RRM A. 78. Somogyi Soma László (Budapest, V. Gerlóczy u. 11.) bejelentését ezúton is köszönjük. Somogyi Soma László elmondta, hogy a halmok úgy ültek a szántföldön, mint „gombok a mellényen”. Esetleg innen származik a Gombos elnevezés, a Juta-Gombosi-erdei halomsírok esetében is.

45 Németh Péter Gergely terepbejárása 2014.

46 Németh Péter Gergely terepbejárása 2008. RRM A. 2513. KÖH 59356. lelöhely.

47 KÖH 47656. , 59355. és 59357. lelöhely. 2014-es helyszínelés során felmerült, hogy a temetőtőhöz több halom is tartozik. A temető felmérése után próbafeltárással lehet majd eldönteni a keltezést.

48 Melhárd 1882, 42-43.

49 Németh Péter Gergely terepbejárása 1999. RRM A. 1383. KÖH 30402. lelőhely. A halmokra Berta Gyula (Kaposvár, Pete u. 8.) hívta fel a figyelmünket, melyet ezúton is köszönünk. utaló leletek gyűjthetők. A halomsírmező a lengyeltóti kora vaskori földvártól és az ottani halomsírmezőtöl délre, mintegy $3 \mathrm{~km}$-re található. A lelöhelyek viszonylagos közelsége és a kőpakolás megléte miatt az öreglaki halmok is a kora vaskorba tartozhatnak, de a római telep egybeesése miatt a római keltezés sem zárható ki. Elöfordulhat, hogy a Nagyberki-szalacskai példához hasonlóan, itt is lehetnek római halmok a kora vaskoriak között.

Római kori leletek:

A 2. halomtól nyugatra:

1. Edénytöredék

Rádlimintás, barna festett töredék, belül szürke festéssel. H: 2,5 cm. Sz: 2,5 cm. Fv: 0,7 cm. Lsz: R.2003.10.1. (XI. t. 11.)

2. Dörzstál töredéke

Dörzstál aljtöredéke, porózus, világosbarna. H: 7 cm. Sz: 6 cm. Fv: 1,3 cm. Lsz: R.2003.10.2.

3. Edénytöredék

Éles hastörésvonalú, porózus, világosbarna. Esetleg az előző edény darabja. $\mathrm{H}: 4,2 \mathrm{~cm}$. Sz: $3,6 \mathrm{~cm}$. Fv: 0,7 cm. Lsz: R.2003.10.3.

4. Oldaltöredék

Ívelt, vastag falú, simított, világosszürke. $\mathrm{H}: 3 \mathrm{~cm}$. Sz: 4 cm. Fv: 0,9 cm. Lsz: R.2003.10.4.

A patak északi partja:

1. Edénytöredék

Vékonyfalú, rádlimintás, barna, narancssárga festéssel. H: 4,1 cm. Sz: 3,9 cm. Fv: 0,4 cm. Lsz: R.2003.10.5. (XI. t. 12.).

2. Oldaltöredék Vékonyfalú, barna, narancssárga festéssel. $\mathrm{H}: 2,7$ cm. Sz: 1,7 cm. Fv: 0,4 cm. Lsz: R.2003.10.6.

3. Aljtöredék

Talpgyürüs edény aljtöredéke. Barna, barna festéssel. H: $6 \mathrm{~cm}$. Sz: 5,7 cm. Fv: 1,1 cm. Lsz: R.2003.10.7.

4. Oldaltöredék

Enyhén ívelt töredék, esetleg az előző edényhez tartozik. H: $6,5 \mathrm{~cm}$. Sz: $3,5 \mathrm{~cm}$. Fv: 0,8 cm. Lsz: R.2003.10.8.

5. Fültöredék

Nagyobb edény két bordával tagolt fültöredéke. Finoman iszapolt, világosbarna. $\mathrm{H}: 4,5 \mathrm{~cm}$. Sz: 3,8 cm. Fv: 1,1 cm. Lsz: R.2003.10.9.

6. Fültöredékek

Szélein kiemelkedő fültöredékek. Finoman iszapolt, szürke. H: 4,8 cm. Sz: 2,2 cm. Fv: $1,1 \mathrm{~cm}$ és $\mathrm{H}: 3 \mathrm{~cm}$. Sz: 3,5 cm. Fv: 0,5 cm. Lsz: R.2003.10.10. és 13.

7. Peremtöredékek

Különböző edények kihajló, profilált, szürke és kékesszürke színú peremtöredékei (5 db). Átlagos Fv: 0,6 cm. Lsz: R.2003.10.11. (XI. t. 13-14.)

8. Fedötöredékek

Különböző edények szürke és kékesszürke színü peremtöredékei $(3 \mathrm{db})$. Átlagos Fv: 0,5 cm. Lsz: R.2003.10.12. 
9. Aljtöredékek

Különböző edények szürke és kékesszürke színű töredékei (2 db). Átlagos Fv: $0,7 \mathrm{~cm}$. Lsz: R.2003.10.13.

10. Oldaltöredékek

Különböző edények (fazekak?) szürke- és kékesszürke színű töredékei (4 db). Az egyik töredék seprüdíszes. Átlagos Fv: 0,9 cm. Lsz: R.2003.10.14-16.

11. Vassalak

Amorf töredékek. Átlagos Á: $4,5 \mathrm{~cm}$. Lsz: R.2003.10.17. A vassalakok a kelta telephez is tartozhatnak.

\section{Somogyaszaló - Halomi-dülő}

A Deseda-erdei római halomsíroktól 3 km-re, északra, magányos halomsír található, tetején háromszögelési ponttal. Becsült méretei: magasság 0,4 méter, átmérő 10-15 méter. Terepbejárás során, a halmon kora bronzkori (Somogyvár-Vinkovci kultúra) és kora vaskori kerámiatöredékek kerültek elö, mely alapján a halmot feltételesen őskorinak tarthatjuk. ${ }^{50}$

\section{Somogyszob - Kisküvölgy}

A Küvölgyi-erdőben, a Somogyszob-Kaszó közötti útról észak felé letérve, a Taranyi-Rinya-ág hídja után keletre található a lelőhely. ${ }^{51} \mathrm{~A}$ temetőt legalább 7 halom alkotja. Az említett erdei út két halmot vág félbe, a nyugati halom betöltésében égett-paticsos rész figyelhető meg. Az erdei utat kerítés szegélyezi délről, a nem müvelt területen több halomszerü kiemelkedés látszik, kettő közvetlenül a kerítés mellett. Az erdei útban patics és ködarabok látszanak, feltehető, hogy az út kialakításakor több halmot elegyengettek. A temetőt északról lápos-zsombékos terület határolja, északnyugati irányban, távolabb, egy kerítéssel lezárt területen nagyobb kiemelkedés látszik, halomsír voltja bizonytalan. A kb. 15-20 m átmérőjű, kb. 3-5 m magas halmok kialakításakor valószínúleg a lápos terület miatt, feltehetően előzetes „tereprendezést” végeztek, így a temetkezőhelyek (a tulajdonképpeni halmok) mérete jelentősen kisebb. A temetőt az út kialakítása mellett földkitermelésekkel is megbolygatták, kisebb beásások is megfigyelhetők, több halmon. A temető pontos kiterjedése nem ismert. A környezetében, esetleges hozzátartozó telep megkeresése miatt, a terep fedettsége miatt, terepbejárást nem lehet végezni. A temető korát csak ásatással lehet tisztázni.

\section{Zala - Halomi-dülö}

Zalán a községtől északra lévő Halomi-dűlő északi részén sikerült beazonosítani egy magányos halomsírt. A halom átmérője kb. 15 méter, magassága $\mathrm{kb}$. 0,5 méter, tetején háromszögelési pont található. Az észak-déli irányú szántás, a keleti és nyuga-

50 Kocztur 1964, 130. és Honti Szilvia-Németh Péter Gergely terepbejárása, 1993. RRM A. 533. KÖH 32362. lelöhely. A halom pontos helyét Berta Árpád (Somogyaszaló, Kossuth u. 86.) mutatta meg, melyet ezúton is köszönünk.

51 A temetöre Várvizy Péter somogyszobi lakos hívta fel a figyelmünket, a bejelentését ezúton is köszönjük. RRM A. 2665. KÖH 69845. lelöhely. ti oldalát részben lepusztította. Formája hasonló a Somogyaszaló-Halomi-dűlőben lévő halomhoz, esetlegesen ez is öskori. ${ }^{52}$

\section{Zamárdi - Diászó}

Halomsírra utaló adatunk van Zamárdiból, azonban terepbejárás során nem sikerült megtalálni, valószínüleg elpusztult. ${ }^{53}$

\section{Negatív bejárások}

\section{Balatonszemes - Községi temető (Sapkadomb)}

A temetőben található domb nem halomsír. Melhárd Gyula feltételezése szerint, a közeli középkori várhoz tartozó megfigyelőhely lehetett. ${ }^{54}$ Sági Károly szerint elképzelhető, hogy kora vaskori halmot később megfigyelöhelynek használtak. ${ }^{55} \mathrm{~A}$ Sapkadomb azonban, mérete alapján, nem lehet halomsír. Nováki Gyula és Sándorfi György 1987. évi bejárása és felmérése tisztázta, hogy kisebb középkori vár található a temetőben. ${ }^{56}$

\section{Baté - Halomi-dúlő}

A Halomi-dűlőben halomsírra utaló jelenség nem található. ${ }^{57}$

\section{Bedegkér - Halom-tető-dülő}

A Halom-tető természetes domb, halomsírt nem lehet találni. ${ }^{58}$

\section{Bonnya - Községi temető}

A temető mellett található kiemelkedés található középkori megfigyelőhely lehetett. ${ }^{59}$

\section{Felsőmocsolád - Királyasztala}

A területen halomsír nem található. ${ }^{60}$

\section{Fonó - Nagy-halom}

A Nagy-halom természetes domb, halomsír nem lehet. ${ }^{61}$

\section{Juta és Várda között}

$A z$ 1:10000 léptékű térképszelvények kiemelkedő tereppontokat jeleznek a két község területére eső Zahoránszki-dűlőn. A bejárás során halomsírt nem lehetett találni. ${ }^{62}$

52 Németh Péter Gergely terepbejárása 1996. RRM A. 871. KÖH 33364. lelöhely.

53 Rómer 1878, 157. Németh Péter Gergely terepbejárása 1995

54 Melhárd 1882, 42. KÖH 19788. lelöhely.

55 Sági-Cséby 1990, 67.

56 Magyar-Nováki, 2005. 32

57 SMFN 477, 151/20. Németh Péter Gergely terepbejárása 1996

58 SMFN 235, 68/121. Németh Péter Gergely terepbejárása, 1999.

59 Magyar Kálmán terepbejárása 1973. RRM A. 919. KÖH 19650. lelöhely.

60 SMFN 339,111/36. 15 m átméröjü halmot említ, ahol régészeti leletek kerültek elö, de bejárás során semmit nem lehetett találni. Németh Péter Gergely terepbejárása 1995. A Felsőmocsoláddal szomszédos Kisbárapáti területén is található egy Királyasztala helynév (SMFN 246, 73/113.), ennek bejárása, a felsőmocsoládi helyszínelés eredménytelensége miatt, már nem történt meg. A szintén Felsőmocsoláddal határos Fiadon, a Királyréten, az erdőben, néhány kisebb bucka látható, ezek nem halomsírok.

61 SMFN, 444, 144/47. Németh Péter Gergely terepbejárása 1996. 62 Németh Péter Gergely terepbejárása 1994. RMM A. 598. 


\section{Kaposkeresztúr}

Kaposkeresztúr határában kettős halom található, de nem tumulus, hanem természetes domb. ${ }^{63}$

\section{Karád - Sapkadomb}

A Somogy Megye Földrajzi Nevei 225, 64/233. szám alatt jelölt Sapkadomb Andocs-Nagytoldipusztától északra, a Karádhoz tartozó Kistoldipusztához tartozik. A bejárás eredménytelen volt, halomra utaló kiemelkedést nem lehetett találni. ${ }^{64}$ Melhárd Gyula tesz említést halomról a település közeléből, Középtoldipusztáról, ezt sem lehet azonosítani. ${ }^{65}$

\section{Karád-Akasztódombtól északra}

A feltételezett halomsírok megkeresése eredménytelen volt, terepbejárás során csak több, természetes dombot találtunk. ${ }^{66}$

\section{Karád - Fehéregyházi-dülö}

Ismeretlen korú halomsírról történik említés, a bejárás során nem találtuk meg. ${ }^{67}$

\section{Kereki - Sapkadomb}

A Somogy Megye Földrajzi Nevei 188, 48/33. alatt említett kiemelkedés nem található, az intenzív homokbányászás erősen megváltozatta a táj képét, ekkor tủnhetett el a Sapkadomb, így nem tudható, hogy mesterséges kiemelkedés volt-e egyáltalán. ${ }^{68}$

\section{Lad - Hármashalom}

A Somogy Megye Földrajzi Nevei 756, 226/94. alatt említett helynév, a különböző térképeken nem látszik halomsírnak, valamint a Hármas-halom, Négyes-halom helynevek bejárásának eredménytelensége miatt, Ladon terepbejárást nem végeztünk.

\section{Lengyeltóti - Pusztaberény-Berény-rice}

A pusztaberényi gazdaságtól délre, félig felszántott kiemelkedés található, ami mérete alapján nem halomsír. ${ }^{69}$

\section{Mosdós - Hármas-halomi-dülő}

A Nagy-hegy északi, természetes nyúlványai, halomsír nem található. ${ }^{70}$

63 Honti Szilvia feljegyzése, RRM A. 92. és Németh Péter Gergely terepbejárása 1994. Kett Attila (Taszár) több Kaposkeresztúr környéki lelőhelyre hívta fel a figyelmünket, melyet ezúton is köszönünk.

64 Németh Péter Gergely terepbejárása 1996. RRM A. 870

65 Melhárd 1882, 42. és 48.

66 M. Aradi Csilla és Németh Péter Gergely terepbejárása 2015. A feltételezett halmokra Berta Gyula (Kaposvár, Pete u. 8.) hívta fel a figyelmünket, melyet ezúton is köszönünk.

67 M. Aradi Csilla és Németh Péter Gergely terepbejárása 2015. KÖH 600/1068/2004.

68 Németh Péter Gergely terepbejárása 1996. RRM A. 870.

69 Németh Péter Gergely terepbejárása 1999. RRM A. 1383. A feltételezett halomra Berta Gyula (Kaposvár, Pete u. 8.) hívta fel a figyelmünket, melyet ezúton is köszönünk. A Berény-Ricén római kori és középkori telepet lehetett bejárni. KÖH 30403. lelöhely.

70 Németh Péter Gergely terepbejárása, 1997. RRM A. 1169. Ugyanakkor Marton Tibor 2004-es terepbejárása során halmot figyelt meg (KÖH 53374. lelőhely). A lelőhely újbóli bejárása szükséges.

\section{Mosdós - Sárkánytó-puszta}

A Mosdós-deákdombi halmoktól délre, halomsírnak tűnő kiemelkedés látható. A domb északi részének szántás utáni bejárása tisztázta, hogy nem halomsír, hanem természetes domb. ${ }^{71}$

\section{Nagyberki - Tárkány}

A Somogy Megye Földrajzi Nevei (484, 153/127) halmokat említ erről a területröl, de terepbejárás során nem kerültek elő. Elképzelhető, hogy a szalacskapusztai halmokra vonatkozik az utalás. ${ }^{72}$

\section{Nagycsepely}

A község északi részén, az Ady Endre utca déli végénél, térkép alapján feltételezett halomsír. A terepbejárás során kiderült, hogy nem tumulus. ${ }^{73}$ Melhárd Gyula tesz említést nagycsepelyi halomsírról, de ez a valóságban földvár, az ún. Barátok asztala. ${ }^{74} \mathrm{~A}$ Kupavár-alján található kiemelkedés nem lehet halomsír, esetleg örtorony. ${ }^{75}$

\section{Nagyszakácsi - Karikás}

A Somogy Megye Földrajzi Nevei „kör alakú dombsort" említ, de bejárás során halomsírt nem sikerült azonosítani, a Karikás természetes domb. ${ }^{76}$ Melhárd Gyula tesz említést halomról a „szakácsi határban”, ezt nem lehet azonosítani. ${ }^{77}$

\section{Segesd - Nádos-erdó}

A Somogy Megye Földrajzi Nevei (657. oldal) halmokat említ, de bejárás során halomsírt nem sikerült azonosítani. ${ }^{78}$

\section{Somogytúr - Tetves-patak mellett}

A R. Goguey által készített légifotón feltételezett halomsírok látszódtak. Terepbejárás során kiderült, hogy ezek a patakot kísérő mocsárból kiemelkedő szigetek. ${ }^{79}$

\section{Somogyvár - Négyes-halom}

A Somogy Megye Földrajzi Nevei (124, 28/84) alapján bejárt területen halomsír nincs. ${ }^{80}$

71 Németh Péter Gergely terepbejárása, 1997. RRM A. 1169.

72 Németh Péter Gergely terepbejárása, 1998. RRM A. 1233.

73 Németh Péter Gergely terepbejárása, 1995.

74 Melhárd 1882, 42. és 48. KÖH 59822. lelőhely.

75 Honti Szilvia -M. Aradi Csilla és Jankovich-Bésán Dénes terepbejárása 2009. RRM A. 3776. KÖH 59823. lelőhely.

76 SMFN 316, 103/87. Németh Péter Gergely terepbejárása.

77 Melhárd 1882, 42.

78 Németh Péter Gergely terepbejárása 2015. Várvizy Péter (Somogyszob, Petöfi u. 40.) tájékoztatást ezúton is köszönjük. Várvizy Péter korábban, kisszámú, alacsony halmokat figyelt meg. A 2015. évi bejárás eredménytelen volt, de a teljes erdőt és a környékét nem érintette.

79 A légifotó 1996.6.26-án készült. EOV 155.3/552.5., azonosítószám: PCD 1545/33-41. és 46. Németh Péter Gergely terepbejárása 1996. RRM. A. 860

80 Németh Péter Gergely terepbejárása 1999. RRM A. 1383. és Régészeti kutatások Magyarországon 1999. Budapest 2002. 244. 


\section{Szabadi - Római-buckák}

A Somogy Megye Földrajzi Nevei (486-487, 154/53) alapján bejárt területen, csatornázás során megmaradt földbuckák láthatók, melyek nem régészeti objektumok. A terület közelében őskori kerámiatöredékek mellett néhány jellegtelen római kori kerámiatöredék került elő. ${ }^{81}$

\section{Oldaltöredék}

Enyhén ívelt, szürke színű oldaltöredék. $\mathrm{H}: 1,4 \mathrm{~cm}$. Sz: $1,8 \mathrm{~cm}$. Fv: 0,7 cm. Lsz: R.98.14.1.

2. Oldaltöredék

Különböző edények enyhén ívelt, szürke színű töredékei. $A z$ egyik töredék seprüs díszítésü. $H: 3$ $\mathrm{cm}$. Sz: $3,5 \mathrm{~cm}$. Fv: $0,8 \mathrm{~cm}$ és H: 2,1 cm. Sz: 2,4 cm. Fv: 0,4 cm. Lsz: R.98.14.2.

\section{Teleki - Bende-tanya és Tungli-tanya}

Teleki és Nagycsepely térségében, az 1:25 000 térképszelvényen, különálló kiemelkedések látszanak, ezek azonban nem halomsírok. ${ }^{82}$

\section{Római kori halomsírok}

\section{Alsóbogát - Csollányosi-erdő} (korábban: Edde-Alsóbogátpszta-Csalánosi-erdő) ${ }^{83}$

A kelet-nyugati irányban sorakozó halmokat egy erdei út vágja ketté (XIII. t. 1.). Jelenleg 27 halom látható, a temetőtől nyugatra, egy erdei ösvény túloldalán néhány gyengébb kiemelkedés látható, esetleg a halomsírmező ebben az irányban is folytatódott. A 2015. évi helyszínelés során, ami az időközben aljnövényzettől jobban kitisztított erdöben történt, felmerült, hogy a korábbi felméréshez képest több halom alkothatja a temetőt. ${ }^{84}$ Átlagos átmérőjük $970,8 \mathrm{~cm}$, átlagos magasságuk $66 \mathrm{~cm}$. A temetőben 10 nagyobb halom köré rendeződnek a kisebb sírdombok. A keleti részen csak nagyobb halmok vannak.

A temetőtől nyugatra kb. 30-40 m-re, dél-északi irányban húzódó töltés található, amely keleti irányba fordul. Legnagyobb szélessége 3,70 m, magassága $40 \mathrm{~cm}$. Korábban kisebb méretű római útra gyanakodtunk, azonban ez egy korábbi keskenynyomtávú iparvágány töltése. ${ }^{85} \mathrm{Az}$ alsóbogáti római halmoktól 1974-ben kerültek elő leletek. A sírrablás során szétdúlt halmok pontos elhelyezkedését nem ismerjük. A rendőrség által lefoglalt leletek a következők:

81 Németh Péter Gergely terepbejárása 1994. RRM A. 606.

82 Németh Péter Gergely terepbejárása 1995

$83 \mathrm{Az}$ egykoron Eddéhez tartozó Alsóbogát újra önálló település lett. A Csalánosi-erdőnek több névváltozata van (SMFN 380, 117/136.). A halomsírok pontos helyét Stamler Imre somogyjád helytörténész mutatta meg, melyet ezúton is köszönünk. KÖH 19776. lelőhely. A halmokról eddig rövid beszámolók készültek: Csizmadia-Németh 1997, 46-47. és Csizmadia-Németh 2000, 226.

84 M. Aradi Csilla-Németh Péter Gergely terepbejárása. RRM A. 7898.

85 Csizmadia-Németh 1997, 47. Ugyancsak újkorinak bizonyult az a töltés, amely Somogyjád és Osztopán között, a müút mellett látható.
1. Nagyméretü, kétfülü korsó töredékei

Kihajló, kettős gyürüs peremmel. Az osztott fülek a nyak felső harmadától vízszintesen, majd hirtelen ívvel, függőlegesen futnak a vállig. Az egyik oldaltöredéken „futó kutya” díszítés maradt meg (II. t. 3.). Talpgyürüs, porózus anyagú, sárga. Szá.: 11,8cm; Tá.: 9,6 cm. Fv: 0,3 cm. Ltsz: R.93.15.1 (II. t. 1. és 3.)

2. Korsó töredékei

Kétfülü, nagyméretü korsó töredékei, narancssárga festéssel. Rádlimintás, árkolással és hullámvonallal díszített. Fv: 0,6 cm. Ltsz: R.93.15.3. (II. t. 4.)

3. Gömbös testü urna töredékei.

Kihajló, bordázott peremű, narancssárga sávos festéssel, árkolásokkal és rádlimintás díszítéssel. Halványsárga, porózus anyagú. Szá.: 16,6 cm. Fv: 0,6 cm. Ltsz: R.93.15.2. (II. t. 6.)

4. Tál töredékei

Kihajló peremű, talpgyűrüs tál töredékei. Árkolásokkal, rádlimintával és bepecsételéssel díszített. Téglasárga alapszínü, felületen erősen lekopott fekete festéssel. Pannóniai szürke áru, Drag. 37. tál utánzata. Szá: 19,5 ; Fá.: 7,5cm. Ltsz: R.93.15.4. (II. t. 5.)

5. Korsó töredékei

Nagyméretű korsó alj-és oldaltöredékei (71 db). Az egyik töredéken a fül indulásának helye megmaradt. Árkolások közötti kettős hullámvonallal és rádlimintával díszített. A fenék talpgyűrűs. Porózus, kopott, halványsárga-szürke. Fv: 0,7 cm. Ltsz: R.93.15.15. (II.t. 7-10.).

6. Fazék töredékei

Gömbös testű, kihajló peremú, levágott peremszéllel, seprüs díszítéssel. Kaviccsal soványított, világosszürke anyagú, másodlagos égésnyomokkal. Szá: 16,3 cm; Fá: 9,8 cm. Fv: 0,4 cm. Ltsz: R.93.15.5. (III. t.6.)

7. Fazék töredékei Kihajló, levágott peremű, gömbös testű fazék töredékei. Az edénytesten ívelt seprüs díszítésszel. Világosszürke. Fv: 0,6 cm. Ltsz: R.93.15.6. (III. t. 11.)

8. Fazék töredékei

Kihajló, levágott peremű, gömbös testű fazék töredékei. A nyak és a váll találkozásánál árkolás fut körbe. Kékesszürke. Szá: 10,5 cm. Fv: 0,3 cm. Ltsz: R.93.15.7. (III. t. 5.)

9. Táltöredék

Háromlábú tál kaviccsal finoman soványított, világosszürke színü töredékei. A hason három borda fut körbe. Tör. M: 4,9 cm. Tá: 6,6 cm. Ltsz: R.93.15.9. (III. t. 10.)

10. Táltöredékek

Behúzott peremű táltöredékek, porózus, barna, narancssárga, kopott festéssel. Pompeji vörös tál pannóniai utánzata. Fv: 0,5 cm. Ltsz: R.93.15.10. (IV. t. 4.)

11. Táltöredékek

Kisméretű, kihúzott peremű alacsony talpgyűrüs tálak töredékei, barna színű festéssel. Ltsz: R.93.15.11-13. (IV. t. 1-3.) 
12. Edénytöredékek

Legalább három edény rádlimintás és barna, ill. narancssárga festett oldaltöredékei. Átlagos Fv: 0,6 cm. Ltsz: R.93.15.14. (II. t. 2.)

13. Fazék töredékei

Kihajló, csaknem vízszintes peremü, gömbös testü fazék töredékei. A nyakon korongolásból származó árkolások futnak körbe. Szürke. Szá: 14,2 cm. Fv: 0,4 cm. Ltsz: R.93.15.16. (III. t. 7.)

14. Fazék töredékei

Kihajló, profilált peremű fazék töredékei. A nyakon korongolásból származó árkolások futnak körbe. Kékesszürke. V: 0,4 cm. Ltsz: R.93.15.17. (III. t. 4.)

15. Fazék töredékei

Kihajló, csaknem vízszintes peremü, gömbös testü fazék töredékei. A nyakon és a peremen korongolásból származó árkolások futnak körbe. Kékesszürke. Fv: 0,4 cm. Ltsz: R.93.15.18. (III. t. 8.)

16. Fazék töredékek

Kihajló peremtöredék és hasonló anyagú aljtöredék, valószínűleg egy edény darabjai. Kaviccsal finoman soványított, keményre kiégetett, szürke. Fv: 0,3 cm. Ltsz: R.93.15.20. (III. t. 3.)

17. Fazekak peremtöredékei Kihajló, profilált peremtöredékek. Az egyiknél, a nyakon, korongolásból származó árkolások futnak körbe. Szürke, a másik szürke, belül barna. Fv: 0,3 cm. Ltsz: R.93.15.22. (III. t. 1-2.)

18. Edény töredékei

Vékonyfalú, kisméretű edény kihajló peremtöredékei. A nyakon bordák futnak körbe. Világosszürke. Fv: 0,3 cm. Ltsz: R.93.15.23. (V. t. 1.)

19. Táltöredékek

Behajló peremü peremtöredékek. Kopott, szürke. Fv: 0,7 ill. 0,8 cm. Ltsz: R.93.15.24-25. (IV. t. 8. és 11.)

20. Táltöredék

Behajló peremü töredék, jól látható korongolás nyomokkal. Kopott, világosbarna. Fv: 0,6 cm. Ltsz: R.93.15.26. (IV. t. 10.)

21. Peremtöredék Kihajló, profilált peremtöredék. Porózus, tégla sárga. Kiszerkesztett Szá.: 6,6 cm. Ltsz: R.93.15.27. (IV. t. 7.)

22. Fedőtöredékek

Fedő árkolásokkal díszített peremtöredékei. Szürke, narancssárga festéssel. Fv: $0,5 \mathrm{~cm}$. Ltsz: R.93.15.28. és 34- 35. (V. t. 6. és 9.)

23. Fedők töredékei

Enyhén ívelt, összeillő peremtöredékek és egy hasonló fedő peremtöredéke másodlagos megégés nyomaival. Okker alapszínü, szürke. Kiszerkesztett Á.: 10,6 cm; 10,2 cm. Ltsz: R.93.15.29. (IV. t. 9.)

24. Aljtöredékek Különböző nagyméretű edények aljtöredékei másodlagos égés nyomaival. Szürke, ill. barna alapszínűek. Átlagos Fv: 0,5 cm. Ltsz: R.93.15.31-33. (IV. t. 5. és V. t. 3-4. és 7.)
25. Aljtöredék

Vékony falú edény aljtöredéke árkolásokkal és bepecsételéssel díszítve. Világosbarna. Fv: $0,5 \mathrm{~cm}$. Ltsz: R.95.15.30. (IV. t. 12.)

26. Fazekak oldaltöredékei Különböző edények vékony falú, jól kiégetett töredékei. Fv: 0,4 cm. Ltsz: R.93.15.36-38. (IV. t. 6.,13. és V. t. 5.)

27. Aljtöredék Profilált aljtöredék. Porózus, barna, barna festés nyomaival. Fv: 0,7 cm. Ltsz: R.93.15.21. (V. t. 8.)

28. Táltöredékek

Kihajló peremü, kaviccsal finoman soványított tál, szürke foltos barna színü töredékei. $F v: 0,5 \mathrm{~cm}$. Ltsz: R.93.15.19. (V. t. 2.)

29. Fedő töredékei

Korongolásból származó árkolásokkal, keményre kiégetett, világosszürke. Tör. $M: 3,5 \mathrm{~cm}$. A fogórész Á: 3,3 cm. Ltsz: R.93.15.8. (III. t. 9.)

30. Üvegedény töredékei

Vékonyfalú, fehér színű töredékek. V: $0,1 \mathrm{~cm}$. Ltsz: R.93.15.39. (V. t. 10-12.)

A bepecsételéssel díszített aljtöredék (IV. t. 12.) az 1 . és 2. század fordulóján készült. ${ }^{86}$ Hasonló díszítést találunk az edénytest külső oldalán egy solymári ${ }^{87}$ és egy zalalövői edényen.$^{88} \mathrm{Az} 1$. és 2 . század fordulójára keltezhető egy töredékesen megmaradt mélytál (V. t. 2.). ${ }^{89} \mathrm{Az}$ alacsony talpgyürüs, barna festett tálak (IV. t. 1-3.) már a 2. század első felére jellemzőek. ${ }^{90}$ Behajló peremű táltöredékek (IV. t. 8. és 10-11.) a 2. századi, díszítetlen katonatálak csoportjába tartoznak. ${ }^{91} \mathrm{Az}$ egyik, töredékesen megmaradt tál (IV. t. 4.) pompeji vörös tál pannóniai utánzata, és a 2-3. századra keltezhető. Egy másik, árkolásokkal, rádli mintával, fekete festéssel és bepecsételéssel díszített tál (II. t. 5.), pannoniai szürke áru, Drag. 37. tál utánzata. A fazekak többsége a korongolt, fésült díszítésű típusba tartozik (III. t. 1-5. és 7-8.) és az 1. és 2. század fordulóján készült. ${ }^{92}$ Két fazék (III. t. 6. és 11.) a pátkai típusba sorolható. ${ }^{93} \mathrm{~A}$ csaknem ép, narancssárga festésū, árkolásokkal és rádlimintával díszített urna (II. t. 6.) párhuzamát Müllendorfon (Szárazvám) találjuk meg. ${ }^{94}$ Hasonló urna került elő, az 1-2. századra datált, söjtöri temető 7 . és 10 . sírjából is. ${ }^{95}$ Szintén a söjtöri temetőben találjuk meg a kétfülü korsók párhuzamait. ${ }^{96} \mathrm{Az}$ egyik edényen „futó kutya” motívum figyelhető meg (II. t. 1. és 3.), egy másik rádlimintás, árkolással és hullámvonallal, valamint narancssárga festéssel díszített (II. t. 4.). Árkolások közötti kettős hullámvonallal és rádlimintával díszített egy harmadik edény (II. t. 7-10.). Több oldaltöredék részben az előző edényekhez tartozhat, vagy további, hasonló

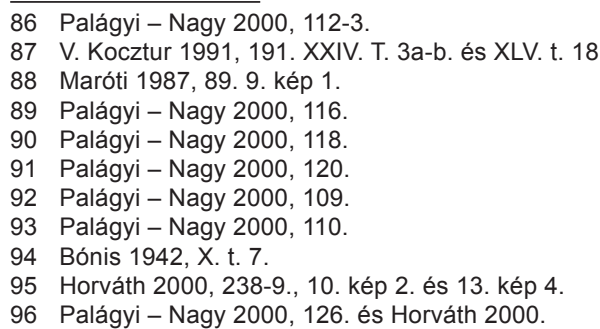

86 Palágyi - Nagy 2000, 112-3.

és XLV.t. 18

91 Palágyi - Nagy 2000, 120.

92 Palágyi - Nagy 2000, 109

95 Horváth 2000, 238-9., 10. kép 2. és 13. kép 4.

96 Palágyi - Nagy 2000, 126. és Horváth 2000. 
urna darabjai (II. t. 2.). Egy barna festés nyomait magán viselő aljtöredék (V. t. 8.) valamelyik korsóhoz tartozhatott. $A z$ alsóbogáti leletek között megmaradt egy töredékes, háromlábú tál is (III. t. 10.), keltezése megegyezik a korsókéval. ${ }^{97}$ Valamelyik fazékhoz tartozott a legjobb állapotban megmaradt fedő (III. t. 9.), hasonló darabok a solymári temetőben fordulnak elö. ${ }^{98}$ Több fedőtöredék is előfordul, az egyiken másodlagos égés nyomai maradtak meg (IV. t. 9.), egy másik edényhez tartozó töredékeket, árkolásokkal és narancssárga festéssel díszítettek (V. t. 6. és 9.). Nem keltezhető pontosan a töredékesen megmaradt üvegedény (V. t. 10-12.).

A leletek alapján a temetkezések a 1. és a 2. század fordulóján indulnak. Sok lelet már a 2. századra keltezhető, sőt a pompeji vörös tál pannoniai utánzata (IV. t. 4.) akár a 3. században is készülhetett.

Alsóbogát és a szomszédos Edde területének teljes régészeti bejárása megtörtént, számos római kori telep vált ismertté. ${ }^{99}$ A Csollányosi-erdőből 4. századi kisbronzról van tudomásunk. ${ }^{100}$ Alsóbogátpusztán Valens érem ${ }^{101}$ és zöldes színü üvegpohár töredékei kerültek elő. ${ }^{102}$

\section{Irregszemcse - Csehipuszta}

Az egykoron Somogy, ma már Tolna megyéhez tartozó Csehipuszta határából, Wosinszky Mór említ több száz síros, római kori temetőt, a halmok ma már nem találhatók meg. ${ }^{103}$

\section{Nagyberki - Szalacska}

Kora vaskori halomból elökerült, római kori kerámiáról tesz említést Rómer Flóris. ${ }^{104}$ A 19. század végén Melhárd Gyula római halmokat tárt fel, de nem tudjuk, hogy hol végezte az ásatást. ${ }^{105}$ Szűkszavú beszámolójában említést tesz arról, hogy néhány kisebb halmot ásott ki és római kori edénytöredékeket és tárgyakat talált. ${ }^{106}$ A szalacskai halomsírmezőt a Szent-kúti-dűlő zárja le, itt, egy erdős-ligetes területen, 12 halom maradt meg, melyek közül többet kiraboltak. Az egyik rabolt halomból kora vaskori kerámiatöredékek, egy másikból vékony falú római kori pohár és üvegedény töredékei kerültek elő. ${ }^{107}$ Ez alapján a kora vaskori halmok között - nem szétválaszthatóan - római halmok is lehetnek.

97 Palágyi - Nagy 2000, 120

98 V. Kocztur 1991

99 Alsóbogáton a KÖH 19759., 19780. és 21143. lelőhely, Eddén a 19383. és 34636. lelőhely.

100 Kocztur 1964, 37.

101 Numizmatikai Gyűjtemény. Ltsz: 62.26.1.

102 KÖH 19804. lelőhely

103 Wosinsky 1896, 764. Németh Péter Gergely terepbejárása 1999. Gaál Attilának a Tolna megyei bejárás engedélyezésért, Ódor János Gábornak az Csehipusztára vonatkozó adattári anyag megküldésért tartozunk köszönettel.

104 Rómer 1878, 115-121. és M. Kabay 1960, 46-49. KÖH 47877. és 56873. lelöhely.

105 Melhard 1900, 390

106 Kérdéses, hogy Melhárd valóban római kori halmokat tárt fel, vagy itt is inkább római kori utótemetkezéssel kell számolnunk.

107 Németh Péter Gergely terepbejárása, 1997. RRM A. 1169. KÖH 32370. lelőhely.

\section{Nagyberki - Szent-kúti-dúlö}

1. Üvegedény töredékei

Üvegedény peremtöredéke és valószínűleg hozzátartozó oldaltöredék. Zöldesfehér. H: 3, cm. Sz: 1,3 $\mathrm{cm}$. V: 0,01 cm. és H. 2,3 cm. Sz: $1,2 \mathrm{~cm}$. V: 0,01 cm. Ltsz: R.2004.15.1. (XI. t. 9-10.)

2. Pohár töredékei

Kihajló peremü pohár két peremtöredéke és egy oldaltöredéke. Finoman iszapolt, barna. Átlagos Fv: 0,4 cm. Ltsz: R.2004.15.2. (XI. t. 6-7.)

2. Oldaltöredékek

Hasonló anyagú és hasonló színű oldaltöredékek (3 $\mathrm{db})$, valószínüleg az előző edény további darabjai. Átlagos Fv: 0,4 cm. Ltsz: R.2004.15.3. (XI. t. 8.)

\section{Orci-Cseri-erdó}

A római temető 7 halomból állt, kelet-nyugati irányban sorakoztak, magasságuk $40-50 \mathrm{~cm}$ volt. Eredetileg Orci falutól nyugatra, a zimányi határban, a Cserierdőben helyezkedtek el. Az 1970-es években 5 halom még látszott, ma már nem találhatók meg, szántás során semmisültek meg. ${ }^{108} \mathrm{~A}$ terület északnyugati részén kis vízfolyás található, de itt a terület fedettsége miatt a telep felderítésére végzett terepbejárás eredménytelen volt, mindössze egy őskori (Urnamezős Kultúra) és egy középkori edénytöredék került elő. ${ }^{109}$ Orciból csak szórványleletet ismerünk a római korból. ${ }^{110}$

1934-ben Gönczi Ferenc két halomban végzett ásatást. ${ }^{111}$ A 4. halomból alacsony talpgyűrün álló tálka, edénytöredék, érme és vasszeg, a 6. halomból FORTIS fenékbélyeges firmamécses és egy másik hasonló mécses töredéke került elő. Kocztur Éva 1961ben, terepbejárás során, az egyik halom tetején, Hadrianus nagybronzot talált. ${ }^{112}$

\section{Leletek a 4. halomból:}

1. Tál

Kihajló peremű, alacsony talpgyürüs tál. A peremen és belül a perem alatt, árkolt. Világosbarna, narancssárga festéssel. Kiegészített. M: $3,2 \mathrm{~cm}$. Szá: 10,2 cm. Tá: 3,7 cm. Ltsz: 9157. (I. t. 1. és 1. ábra.)

2. Edénytöredék

3. 1. századi érme

4. Vasszög

A 6. halom leletei:

1. Mécses Ép firmamécses, a többszörös árkolásos FORTIS fenékbélyeggel. Barna, kopott narancssárga festéssel, a szájnyílásnál égésnyommal. $M: 3,1 \mathrm{~cm}$. $\mathrm{H}: 8 \mathrm{~cm}$. SZ: 5,4 cm. Ltsz: 9161. (I. t. 2.)

2. Mécses töredéke

108 Samu Sándor zimányi lakos tájékoztatását ezúton is köszönjük 109 Németh Péter Gergely terepbejárása, 1994. RRM A. 608. KÖH 47965. lelöhely.

110 Wessetzky 1983

111 Kocztur 1964, 105. Ma már csak a tál és az ép mécses van meg, leltári számuk: 9157 . és 9161 . A szakleltárkönyv bejegyzése szerint, a leletek a mernyei piarista uradalom kormányzóságának ajándékaként kerültek be a kaposvári múzeumba.

112 Kocztur 1964, 105. Az érme elveszett. 


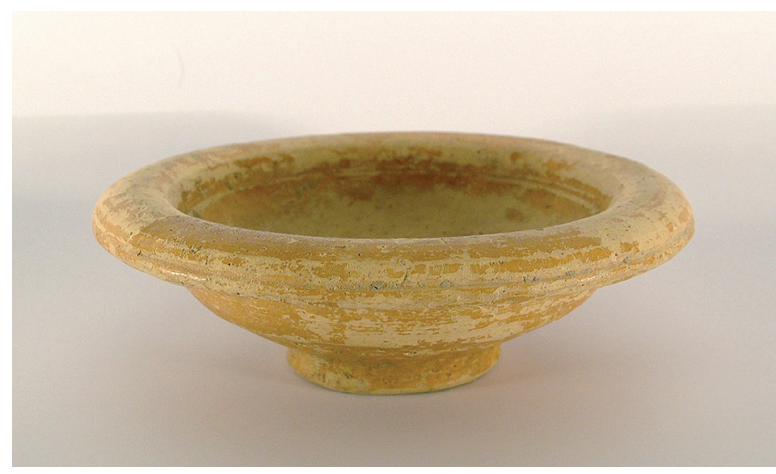

1. ábra. Tál Orciból

A jelenleg meglévő mécses Iványi XVII. típusba tartozik. ${ }^{113}$ A FORTIS bélyeges mécsesek már az 1 . században megjelennek. ${ }^{114}$ A 4. halom tálja a Traianus - Hadrianus császárok uralkodása alatt gyártott, DRAG. 36-os terra sigillatát utánoz. ${ }^{115}$ A halomsírok a 2. század első felére történő keltezését megerősíti az 1961-ben talált Hadrianus érme.

\section{Somogyaszaló - Deseda-erdő}

A halomsírmező a Somogyaszaló községhez tartozó Deseda-erdőben található. A korábbi szakirodalomban Deseda és Desedapuszta néven is szerepelt. ${ }^{116}$ A 19. században négy halmot kutattak át. ${ }^{117} \mathrm{Az}$ első halomban a halom „két harmadrészének átmetszése után" négy széttörött fekete korsó darabjai és egy ötödik „leborított” korsó, vöröses terra sigillata bögre „közepén kidomborítva, talapzata felé szűkül”. Ez utóbbi edény Ipolyi Arnold gyűjteményébe került. A másodikban teljes lócsontváz volt, melyen nem voltak égésnyomok. A harmadik, korábban bolygatott halomban, „sokféle finomabb, kívülröl vörös, belül mázas korsódarabok" voltak. A negyedik halom közepén töredékes üvegedény került elő, melyben hamuval kevert csontok voltak. A halom leleteihez tartozott még edénytöredékeken kívül két fedő és egy „fehér agyagból készült tányér darab". A leletek ma már nincsenek meg.

A somogyaszalói temető két kisebb és egy nagyobb csoportból áll (XIV. t.). A temető északi részén egy kettős halom található, a nagyobbikon több kőtöredéket találtunk. Ettől délre egy kisebb csoport van. Szabálytalan sorokban álló halmok iránya, a római kori halmos temetőknél megfigyelt, kelet-nyugati irányú. Összesen 68 halom alkotja a temetőt, a halmok átlagos átmérője $854,3 \mathrm{~cm}$, átlagos magassága $59,8 \mathrm{~cm}$. Látszólag a nagyobb halmok vannak túlsúlyban, de valószínübb,

113 Iványi 1935, 25-26

114 Gábli 2014, 40

115 Palágyi - Nagy 2000, 118. Az edénytípus nemcsak halomsírból ismert, az orcihoz hasonló tálka került elő a kékesdi temető 29. szórthamvasztásos sírjából (Sz. Burger 1966, 262. és 267. oldal, 4. kép 29/3., 9. kép 6.).

116 Ipolyi 1861, 294., Rómer 1878, 157., Barkóczi 1956, 78. és RRM.A. IV/58/2. és 3-4. Rómer térképén (Kapos) Füreden is jelöl halmokat, ezek azonban azonosak a somogyaszalói temetővel. A lelöhelyet helyesen említi Sági 1943, 121. KÖH 45227. lelöhely.

117 Az első három leírása: Ipolyi 1861, 294., a negyediké: Melhárd 1882a, 54. hogy az eleve kisebb halmok jobban eltüntek. Ezt erősíti az a tény, hogy a somogyaszalói halmok között, pl. a 9. és 21. halom esetében, nem is tudtunk mérni, mert ezek a halmok már csaknem eltüntek. 1996-ban két halmot tártunk fel. ${ }^{118}$

1. halom. Átmérője: $112 \mathrm{~cm}$, magassága: $80 \mathrm{~cm}$. Bolygatásnak nincs nyoma, csak néhány kisebb fa található a szélén. A fahelyeket és a halom északi szélét nem tártuk fel (XV. t. 1.).

A halmot $\mathrm{K}-\mathrm{Ny}$-i irányban tüztük ki, a halom déli része az I. szelvénybe esett. 40-60 cm mélységből, a szelvényfalhoz közel, fazék töredékei, hamvak és kevés faszén került elő, szétszórva. Középen kirajzolódott a sír foltja, betöltése égett, faszenes, benne nagyobb fazéktöredék, kisebb edények, edénytöredékek és állatcsontok voltak. A sírgödör szélei nem teljesen kivehetők, tulajdonképpen a faszenes, égett, belső része határozza meg a kiterjedését. Tájolása: ÉNY-DK, hosszúsága $175 \mathrm{~cm} \mathrm{~cm}$, szélessége $105 \mathrm{~cm}$, mélysége $7 \mathrm{~cm}$. A gödör alján csak kevés hamv és faszén volt (XIX. t. 1.). Tovább mélyítettük a sírgödröt, mert kisebb, fekete elszíneződés látszott. Ez azonban egy korábbi fa nyoma, ezért a korábbi sírgödör az eredeti.

Megfigyeléseink alapján a temetkezés kialakítása a következőképpen történt: A kemény, sárga altalajba ásták be a sírgödröt, majd felhordták az egységes anyagú (sárga homok) halmot. A halom eredetileg magasabb és kisebb átmérőjü volt, de nem jelentősebben, és később az időjárás miatt „terült szét”. Rablásnak nincs nyoma, és esetleg elképzelhető, hogy a több más somogyaszalói halomnál megfigyelhető, középső, kisebb besüllyedés talán nem rablás nyoma, hanem inkább a középen lévő sírgödör miatt alakult ki.

\section{Mellékletek:}

1. Tál

Kihajló, profilált peremű alacsony tál, a vállon árkolások futnak körbe. Kaviccsal soványított, kékesszürke. Szá: $14,1 \mathrm{~cm}$. Fá: $5 \mathrm{~cm}$. M: 6,1 cm. Ltsz: R.96.7.1. (VI. tábla 6. és 2. ábra.)

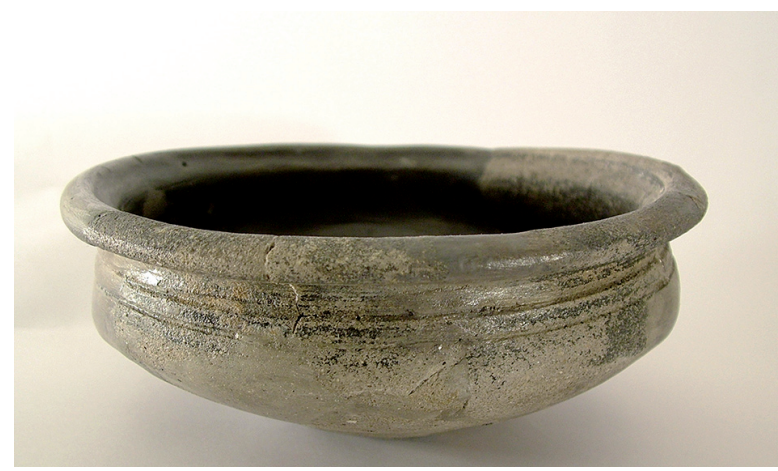

2. ábra. Tál a Somogyaszaló 1. halomból

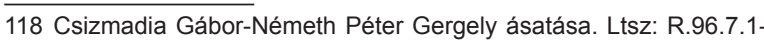
8.15 
2. Pohár töredékei

Kihajló peremü, gömbös testü, vékonyfalú pohár töredékei. Árkolásokkal és többsoros rádli mintával díszített. Porózus anyagú, szürke, barna színű festés nyomaival. Fv: 0,4 cm. Ltsz: R.96.7.2. (VI. t. 8.)

3. Fazék töredékei

Kihajló peremü, a perem és a nyak fésült árkolásokkal díszített. Csillámos felszínű, jól kiégetett, szürke-barna. Fv: 0,3 cm. Ltsz: R.96.7.3. (VI. t. 9.)

4. Fazék töredékei

Hasonló, mint az előző, de vastagabb falú, kékesszürke, kátrányozás nyomaival. Az árkolások alatt hullámvonal fut körbe. Fv: 0,5 cm. Ltsz: R.96.7.4. (VI. t. 1.)

5. Fedőtöredékek

Legalább két fedő peremtöredékei. Sötétszürke.

Fv: 0,4 cm. Ltsz: R.96.7.5. (VI. t. 4.)

6. Oldaltöredékek

Ívelt, porózus anyagú töredékek, valószínűleg egy edény darabjai. Az egyik töredék árkolt és barna festés nyomai látszanak. Fv: 0,7 cm. Ltsz: R.96.7.6. (VI. t. 2-3.)

7. Oldaltöredékek

Korongolt, kopott, kékesszürke színű oldaltöredékek. Fv: 0,5 cm. Ltsz: R.96.7.7. (VI. t. 5.)

8. Oldaltöredék

Korongolt, csillámos felszínü, szürke színü töredék, valószínüleg fazék töredéke. H: $6 \mathrm{~cm}$. Sz: 4,7 cm. Fv: 0,5 cm. Ltsz: R.96.7.8. (VI. t. 7.)

9. Állatcsontok

2. halom. Az 1. halomtól közvetlenül nyugatra lévő halom. Átmérője $950 \mathrm{~cm}$, magassága $50 \mathrm{~cm}$. A halom közepén nem látszott sírgödör miatti besüllyedés, rablásnak nem láttuk nyomát, csak néhány kisebb fa nőtt ki belöle. A fahelyeket, a halom északi és keleti szélét nem tártuk fel (XV. t. 2.).

A déli részen, nagyjából a halom közepéről, kézi korongon készült nagyobb edény töredékei, fazéktöredékek és piros festésü, finoman iszapolt edény töredékei kerültek elő.

A halom közepénél szabálytalan folt alakult ki, melynek bontásakor kiderült, hogy az $1-2 \mathrm{~cm}$ vastag, átégett föld alatt, mintegy $2-3 \mathrm{~cm}$ vastagságban, szétterített faszén, alatta vastagabb, barna színűre átégett föld van, melynek vastagsága $5-7 \mathrm{~cm}$. Ennek a három rétegnek a szétterítése egyenetlen, középen egyenletes betöltésủ sárga homokot találtunk. A három rétegben kevés hamv és néhány kerámiatöredék volt. Az átégett rétegtől keletre kőtöredéket találtunk. A rétegek elbontása után került elő a sírgödör, tehát a máglya földjét szétterítették a sírba tételkor, melyre talán azért lehetett szükség, hogy ily módon, minden hamvat összegyűjtsenek (XIX. t. 2.). A hamvasztás nem a halomnál történt, mert a sír betöltésében kevés faszenet találtunk.

A sírgödör határozottabban rajzolódik ki, mint az 1 . halomnál. Lekerekített sarkú, négyzetes alaprajzú, tájolása ÉK-DNy, hosszúsága $172 \mathrm{~cm}$, szélessége $150 \mathrm{~cm}$, mélysége $21 \mathrm{~cm}$. A sír alja egyenetlen, a sárga altalajba vágva, oldalai csaknem függőlegesek, több helyen állat- járat bolygatta meg. A sír nyugati részén tálat, mellette közvetlenül oldalára dőlt poharat találtunk. A hamvakat szétszórták a sírgödörben, a legtöbb hamv az edényektől északra, valamint az edények oldalához téve került elő. A délkeleti sarokban finoman iszapolt, festett edény töredékei kerültek elő, melynek darabjait korábban, a halom bontásánál már megtaláltuk. A sírgödör keleti részén töredékes Noricum-pannoniai szárnyas fibula került elő. A sír betöltése sötétszürke, alul sárga homok, egyenetlenül keveredik, minimális faszénnel.

A fentiek alapján valószínűsíthető, hogy a hamvasztás után elhelyezték a mellékleteket, majd a máglyáról a földdel és az elégetett fával együtt összegyűjtötték a maradék hamvakat, és ezt úgy helyezték el, hogy nagyrészt, a sírgödör fölé kerüljön.

Mellékletek:

1. Fazék töredékei

Kihajló, profilált peremmel, a nyakon árkolások futnak körbe. Kaviccsal durván soványított. Szürke, belül fekete. Fv: 0,4 cm. Ltsz: R.96.8.1. (VII. t. 1.)

2. Fazék töredékei

Kihajló peremü, nagymérető fazék töredékei. Kézi korongon készült, egyenetlenül kiégetett, csillámos felszínű. Szürke-fekete foltos barna, belül fekete. Fv: 0,5 cm. Ltsz: R.96.8.2. (VIII. t. 3.)

3. Aljtöredék

Finoman iszapolt, porózus anyagú, szürkésbarna. $\mathrm{H}: 4,2 \mathrm{~cm}$. Sz: 2,9 cm. Fv: 0,5 cm. Ltsz: R.96.8.3. (VIII. t. 6.)

4. Tál

Kihajló peremü, alacsony talpgyűrüs tál, a perem belül árkolt. Porózus anyagú, szürkésbarna. Szá: $19,5 \mathrm{~cm}$. M: 30,5 cm. Tá: $12 \mathrm{~cm}$. Ltsz: R.96.8.4. (VII. t. 2.)

5. Pohár aljtöredéke

Finoman iszapolt, kaviccsal soványított, világosbarna. Fá: 4,2 cm. Fv:0,3 cm. Ltsz: R.96.8.5. (VII. t. 5.)

6. Oldaltöredék

Ívelt, vastag falú, fésüdíszes, kaviccsal soványított, világosbarna. $\mathrm{H}: 5,7 \mathrm{~cm}$. Sz: $5,1 \mathrm{~cm}$. Fv: $0,7 \mathrm{~cm}$. Ltsz: R.96.8.6. (VIII. t. 7.)

7. Oldaltöredék

Különböző edények vékonyfalú, enyhén ívelt töredékei. Csillámos felszínú, szürke. Az egyik töredéken árkolások futnak körbe. $\mathrm{Fv}: 0,4 \mathrm{~cm}$. Ltsz: R.96.8.7. (VII. t. 6.)

8. Fedőtöredék

Kaviccsal durván soványított peremtöredék. Egyik oldala szürke, a másik kékesszürke. $\mathrm{H}: 3,8 \mathrm{~cm}$. Sz: $3,3 \mathrm{~cm}$. Fv: 0,3 cm. Ltsz: R.96.8.8. (VIII. t. 5.)

9. Kötöredék Világosbarna mészkötöredék. H: 7,7 cm. Sz: 5,4 cm. Ltsz: R.96.8.9.

10. Bronzfibula töredéke Noricum-pannoniai szárnyas fibula töredéke. Alsóhúros, eredetileg 4+4 rugóelosztású. Tör. H: 2,7 cm. Sz: 1,7 cm. Ltsz: R.96.8.10. (VIII. t. 3.) 


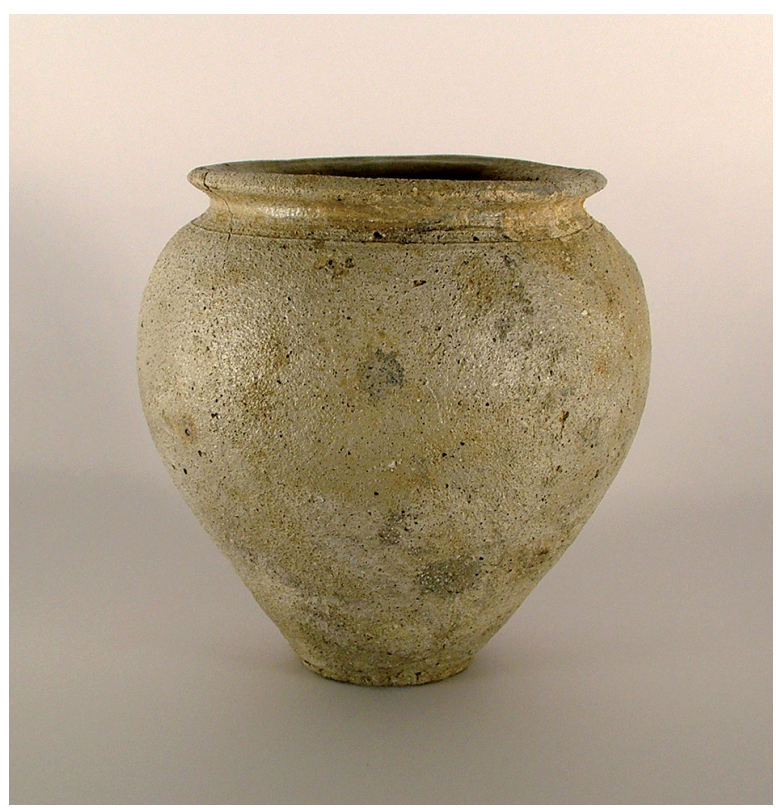

3. ábra. Pohár a somogyaszalói 2. halomból

11. Tál

Kihajló peremű, alacsony talpgyürüs tál, finoman iszapolt, simított, szürke. Szá: $14 \mathrm{~cm}$. M: $4,5 \mathrm{~cm}$. Fá: 6,5 cm. Ltsz: R.96.8.11. (VII. t. 7. és 4. ábra.)

12. Pohár

Kihajló, profilált peremü, barna foltos szürke. Sz: $6,5 \mathrm{~cm}$. Fá: $3 \mathrm{~cm}$. M: $7,5 \mathrm{~cm}$. Ltsz: R.96.8.12. (VII. t. 4. és 3. ábra.)

13. Korsó töredékei

Kihajló peremű, tagolt szalagfüllel, alacsony talpgyűrüs. Az egyik oldaltöredék esetleg egy másik edényhez (fedő?) tartozik. Barna foltos szürke, barna színü festéssel. Fv: 0,4 cm. Ltsz: R.96.8.13. (VIII. t. 2.)

14. Peremtöredék

Kihajló, finoman iszapolt, barna, barna színű festés nyomaival. H: $3,3 \mathrm{~cm} \mathrm{SZ:} 2,1 \mathrm{~cm}$. Fv: 0,7 cm. Ltsz: R.96.8.14. (VIII. t. 4.)

15. Fedő töredékei

Árkolással díszített peremtöredékek, valószínűleg egy edény darabjai. Fv: 0,4 cm. Ltsz: R.96.8.15. (VIII. t. 1.)

16. Állatcsontok. A kerámiaanyag restaurálása során, az egyik tálból kerültek elő.

A somogyaszalói temető fazekai az 1. és 2. század fordulójára keltezett temetők jellegzetes anyaga. ${ }^{119} \mathrm{~A} 2$. halom kézi korongon készült fazeka a pátkai típusba tartozik. ${ }^{120}$ A fazekak mellett több fedőtöredék is előkerült. Az 1. és 2. század fordulójára keltezhető az egyenes peremű tál (VII. t. 1.). ${ }^{121} A z$ 1. halomból előkerült darab (VI. t. 6. és 2. ábra) késő kelta formára vezethető vissza. ${ }^{122} \mathrm{~A}$ virágcserép alakú tál (VII. t. 7. és 4. ábra) párhuzamát a sikátori temetőben találjuk meg. ${ }^{123}$ A negyedik tál párhuzamát a solymári teme-

119 Palágyi - Nagy 2000, 109.

120 Palágyi - Nagy 2000, 110.

121 Palágyi - Nagy 2000, 115-6.

122 Palágyi - Nagy 2000, 115.

123 Palágyi 2014, 116. és 134 . jegyzet.

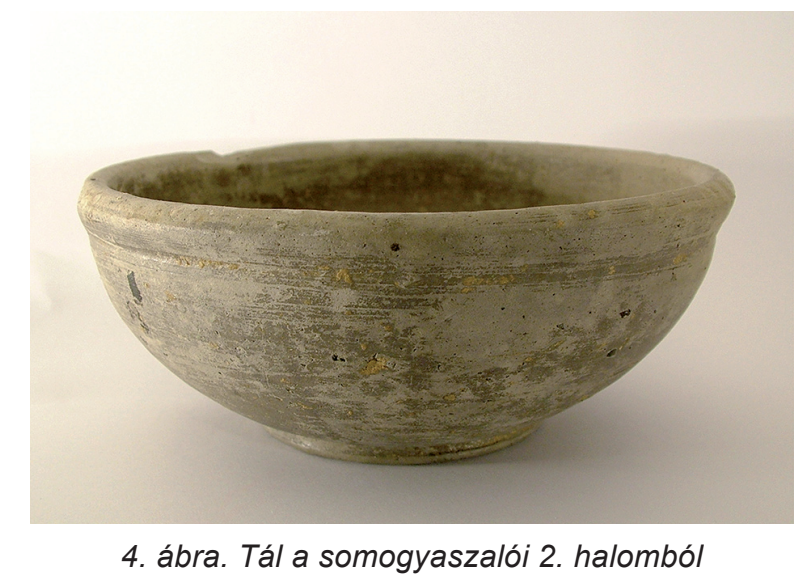

tőben találjuk meg. ${ }^{124}$ A halomsírok gyakori mellékletei közé tartoznak a poharak, Somogyaszalóban a 2. halomból került elő ívelt oldalú, kihajló peremű példánya (VII. t. 4. és 3. ábra). ${ }^{125}$ Hasonló típusba tartozhat az 1 . halom díszített, de töredékes pohara is (VI. t. 7.). A 2. halom töredékes korsója a gömb hasú típusba tartozik (VIII. t. 2.). ${ }^{126} \mathrm{~A}$ temető egyetlen fémlelete, a Noricum-pannoniai szárnyas fibulák közé tartozik (VIII. t. 3.). Keltezése 100-250 közti időszakra tehető. ${ }^{127}$ Mivel a kerámialeletek döntő része az 1 . és 2 . század fordulójára keltezhető, így a somogyaszalói temetkezésekre inkább ekkor kerülhetett sor.

Somogyaszalóban, a halmokhoz vezető földútból, nagyméretű vaslepény került elő. A temetőtől keletre, a Korpadombon és attól nyugatra római telep található, az utóbbi helyen, edénytöredékeken kívül több vassalakot is találtunk. ${ }^{128}$

\section{Somogyaszaló-Deseda-erdőtől keletre}

1. Fazék töredéke

Fazék profilált, vágott, kihúzott peremtöredéke, perem alatt vékony, párhuzamos árkolásokkal. Szürke, kaviccsal soványított. H: $3,9 \mathrm{~cm}$. Sz: $2,8 \mathrm{~cm}$. Fv: 0,7 cm. Ltsz: R.96.2.1.

2. Fazék töredéke

Fazék profilált, vágott, behúzott peremtöredéke. Szürke, kaviccsal soványított. H: $3,3 \mathrm{~cm}$. Sz: 2,1 cm. Fv: 1,3 cm. Ltsz: R.96.2.2.

3. Fazéktöredékek Különböző edények seprüdíszes, kopott, kékesszürke színű töredékei. Átlagos Fv: $0,7 \mathrm{~cm}$. Ltsz: R.96.2.3.

\section{Dörzstál töredéke}

Kihajló, árkolt peremtöredék, zöld színű ólommáz nyomaival a belső oldalán. Téglavörösre égetett, porózus. 8,8 x 3,3 cm. Fv: 1,7 cm. Ltsz: R.96.2.5.

5. Vasalakok

Amorf töredékek. Átlagos Á: 3 cm. Ltsz: R.96.2.4.

\footnotetext{
124 Kocztur 1991, 11. sír. 176. III. t. 13. és XLV. t. 17

125 Palágyi - Nagy 2000, 122.

126 Palágyi - Nagy 2000, 124-5.

127 Palágyi - Nagy 2000, 139-140. és 142.

128 Honti Szilvia - Németh Péter Gergely terepbejárása 1993.10.08. és 10.10. RRM A. 533. KÖH 55844. lelöhely.
} 
Újabb bejárás során, a Korpadombon és attól keletre újabb római kori edénytöredékek kerültek elő. ${ }^{129}$ Ettöl a területtől északkeletre található, a már említett, magányos, általunk feltételesen őskorinak tartott halomsír.

1. Fazék peremtöredéke

Fazék kihúzott peremtöredéke, keményre kiégetett, fekete. H: 5,9 cm. Sz: 2,2 cm. Fv: 0,3 cm. Ltsz: 187.1/1.1.

2. Oldaltöredékek

Különböző edények keményre kiégetett, szürke színü töredékei (3 db). Átlagos Fv: 0,7 cm. Ltsz: 187.1/1.3.

3. Oldaltöredékek

Különböző edények porózus, barna színű töredékei (2 db). Átlagos Fv: 0,5 cm. Ltsz: 187.1/1.4.

4. Aljtöredék

Keményre kiégetett, kopott, szürke. $\mathrm{H}: 4,2 \mathrm{~cm}$. Sz: $3,8 \mathrm{~cm}$. Fv: $1 \mathrm{~cm}$. Ltsz: 187.1/1.5.

A somogyaszalói halomsíroktól nyugatra, már Kaposvár-Kaposfüred területén, a Deseda-patak túlsó partján, kis területen ugyan, de elég sok római tegulaés imbrextöredéket lehet gyűjteni, az előkerült leletek alapján a feltételezhető épület kora: $2-4$. század. ${ }^{130}$

1. Terra sigillata edény töredéke

Drag. 32. tál peremtöredéke, narancssárga. Rheinzaberni mühely. Severusok kora. ${ }^{131} \mathrm{H}: 6,5 \mathrm{~cm}$. Sz: 4,4 cm. Fv: 0,5 cm. Ltsz: R.96.1.1. (IX. t. 4.)

2. Terra sigillata edény töredéke

Drag. 18/31 tál töredéke, narancssárga, Rheinzaberni mühely. Késő Antoninusok-Severusok kora. H: 3,4 cm. Sz: 2,9 cm. Fv: 0,5 cm. Ltsz: R.96.1.2. (IX. t. 2.)

3. Terra sigillata edény töredéke

Drag. 37. tál oldaltöredéke, narancssárga. Díszítése: tojásfüzér (Ri-Fi E 17), alatta kettős körből álló medalion (Ri-Fi K 19), illetve levélmotívum. Rheinzaberni mühely, mestere: Bernhard csoport Ib-Ila. H: 3,5 cm. Sz: $3,5 \mathrm{~cm}$. Fv: 0,5 cm. Ltsz: R.96.1.3. (IX. t. 1.)

4. Terra sigillata edény töredéke

Drag. 37. tál oldaltöredéke, narancssárga. Díszítése: Tojásfüzér (Ri-Fi E3) és gyöngyökből álló félkörív (RiFi KB 95). Rheinzaberni műhely, mestere: BF Attoni. Bernhard csoport lla. Severusok kora. H: 2,7 cm. Sz: $1,5 \mathrm{~cm}$. Fv: 0,5 cm. Ltsz: R.94.1.4. (IX. t. 8.)

5. Terra sigillata edény töredéke

Drag. 37. tál aljrészének töredéke, narancssárga. Lezoux-i mühely. Antoninusok kora. $\mathrm{H}: 4,4 \mathrm{~cm}$. Sz: $3,6 \mathrm{~cm}$. Fv: 0,8 cm. Ltsz: R.98.1.5. (IX. t. 5.)

6. Terra sigillata edény töredéke

Drag. 54. oldaltöredéke, árkolt, narancssárga. Rheinzaberni mühely. Severusok kora. $\mathrm{H}: 3,7 \mathrm{~cm}$. Sz: 1,8 cm. Fv: 0,5 cm. Ltsz: R.96.1.6. (IX. t. 7.)

129 Honti Szilvia - M. Aradi Csilla - Nagy Levente - Németh Péter Gergely terepbejárása, 2006.

130 Eöry Béla (Balatonberény, Kodály u. 34.) gyűjtése 1980-1986 között. RRM A: 533. KÖH 45224. lelöhely.

131 A publikációban szereplő terra sigillata leletek meghatározását Horváth Friderikának ezúton is köszönjük.
7. Terra sigillata edény töredéke

Drag.18/31? oldaltöredéke, narancsssárga. Rheinzaberni mühely. Késő Antoninusok-Severusok kora. H: 3,4 cm. Sz: 2,4 cm. Fv: 0,5 cm. Ltsz: R.96.1.7. (IX. t. 3.)

8. Tál töredéke

Pannóniai szürke áru. Vízszintesen kihajló peremmel, talpgyürüvel. A peremen kettős árkolás és rádliminta, a perem belső oldalán szintén árkolás látható. Erősen kopott. Kiszerkesztett Szá.: $24 \mathrm{~cm}$; Tá.: 8,6 cm. Fv: 0,7 cm. Ltsz: R.96.1.8. (IX. t. 6.)

9. Agyagtégely

Kisméretü, kézzel formázott, csonka kúp alakú agyagtégely, belsejében világosbarna mázzal. Porózus anyagú, sárgásbarna. $M: 2,5 \mathrm{~cm}$. Szá.: 4,5 cm. Fá.: 1,9 cm. Ltsz: R.96.1.10. (IX. t. 10.)

10. Edény töredékei

Nagyobb edény töredékei vízszintesen kihajló, keskeny peremmel. A perem külső szélén egy, a perem alatt az oldalon kettős árkolás és borda látható. Anyaga sárga, porózus, felületén vörös festéssel. Kiszerkesztett Szá.:23,4 cm. Fv: 0,7 cm. Ltsz: R.96.1.9. (IX. t. 9.)

11. Fedő töredékek Különböző edények töredékei. Szürke, kaviccsal soványított. H: $7 \mathrm{~cm}$. Sz: 5,6 cm. Fv: 0,4 cm. H: 2,4 cm. Sz: 2,5 cm. Fv: 0,3 cm. Ltsz: R.96.1.11.

12. Oldaltöredékek

Különböző edények töredékei seprüs dísszel és ferde bevágásokkal, illetve seprüs dísszel. Szürke, kavicscsal soványított. H: 5,5 cm. Sz: 4,1 cm. Fv: 0,8 cm. H: $5,9 \mathrm{~cm}$. Sz: 2,3 cm. Fv: 0,6 cm. Ltsz: R.96.1.12-13.

13. Aljtöredék

Talpgyürüs töredék. Az alj belső oldalán árkolás látható. Okkerszínű, vastag, porózus anyagú. Kiszerkesztett Tá.: $9 \mathrm{~cm}$. Fv: 0,3 cm. Ltsz: R.96.1.14.

14. Fültöredék

Ovális keresztmetszetű töredék. Barna, kopott zöld mázzal. H: 5,1 cm. Sz: 2,4. Ltsz: R.96.1.19.

15. Aljtöredék Csillámos felszínü, kopott, kékesszürke. $\mathrm{H}: 4,3 \mathrm{~cm}$. Sz: $2,9 \mathrm{~cm}$. Fv: 0,9 cm. Ltsz: R.96.1.20.

16. Bronzérme Töredékes, deformálódott érme, 4. századi kisbronz, Ae 3. Ltsz: R.96.1.15.

17. Bronzérme 4. századi kisbronz, Ae3 töredék. Ltsz: R.96.1.16.

18. Üvegedény töredéke Illatszeres üvegedény aljtöredéke. Zöld. Tá: 3,9 cm. Ltsz: R.96.1.17.

19. Imbrextöredékek Jól kiégetett, világosbarna színű töredékek. H: 4,6 cm. Sz: 3,7 cm. Fv: 1,9 cm. H: 7,5 cm. Sz: 10,2 cm. Fv: $1,5 \mathrm{~cm}$. Ltsz: R.96.1.21.

20. Fenőkő töredéke Trapéz keresztmetszetű, barna színű homokkő. H: $3,5 \mathrm{~cm}$. Sz: 3,1 cm. Ltsz: R.96.1.22.

21. Töredékes üveggyöngy Kék színű, töredékes üveggyöngy. Á: $1,3 \mathrm{~cm}$. Ltsz: R.96.1.18. 


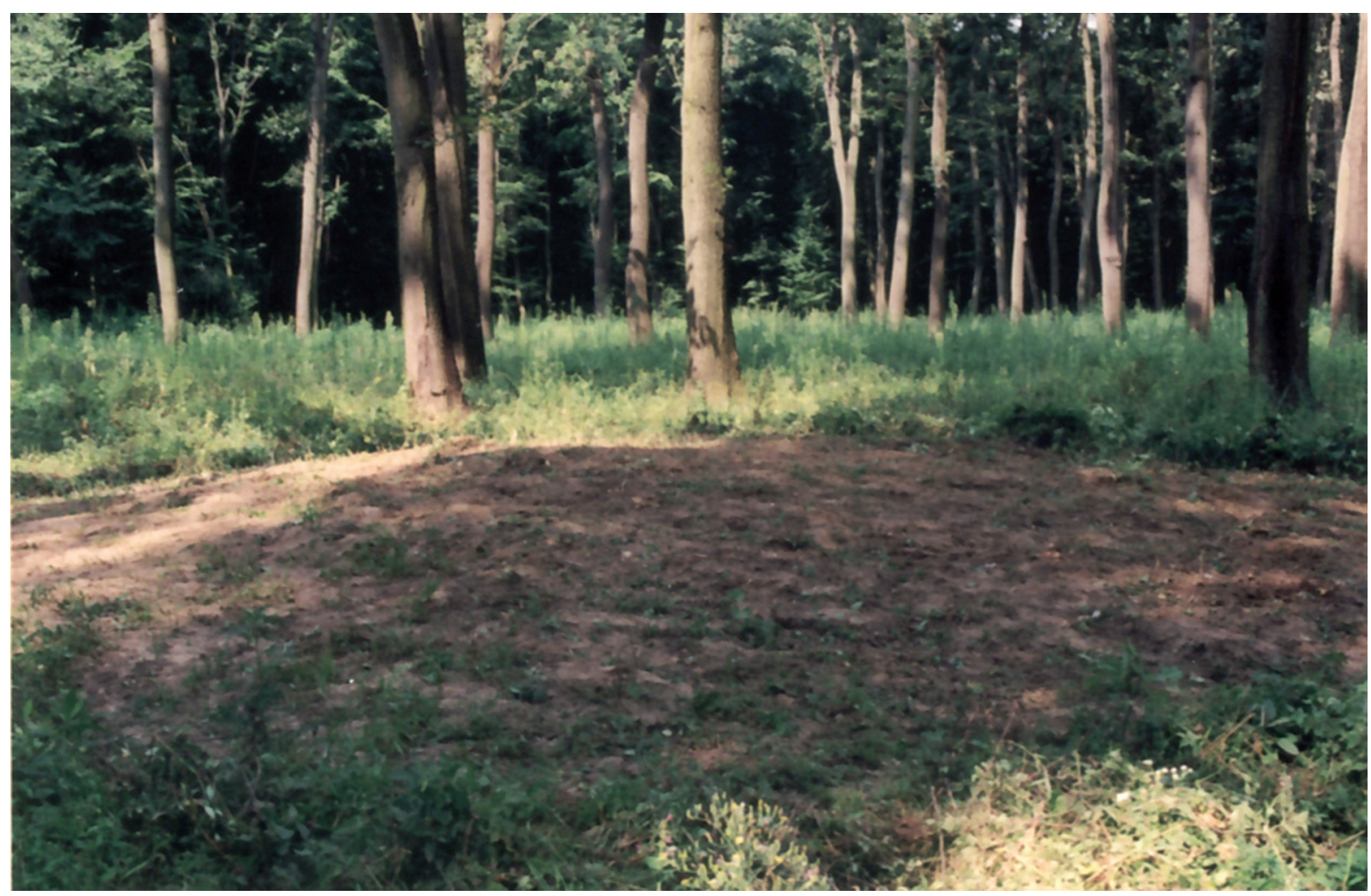

5. ábra. Somogyjádi 1. halom feltárás előtt

\section{Somogyjád - Apánkai-erdő}

Somogyjád községtöl délnyugatra, mintegy $3 \mathrm{~km}$ re, az Apánkai-erdőben, nagykiterjedésű halomsírmező található. Két halomsírt még a 19. században Melhárd Gyula tárt fel, a hamvasztásos sírokban terra sigillata töredékeket talált, melyek közül az egyik díszített volt. ${ }^{132}$ Pusztai Rezső 1955-ben végzett terepbejárása során a környékbeli bronzkori és vaskori települések közelsége miatt a halmokat őskorinak tartotta. ${ }^{133}$ Az 1997-ben és 1998-ban végezett feltárások bebizonyították, hogy a halomsírmező a római korba tartozik. ${ }^{134}$

A sírok száma 180 (XIII. t. 4.). Átlagos átmérőjük $840,4 \mathrm{~cm}$, átlagos magasságuk $43,6 \mathrm{~cm}$. A temető kelet-nyugati irányú, 17 nagyobb halom köré rendeződnek a kisebb sírdombok. A halmok egymástól való távolsága néhány méter. A temető mintegy $10 \%$ - át a jelenkorban kirabolták.

1. halom. A halom átmérõje $120 \mathrm{~cm}$, magassága $52 \mathrm{~cm}$, felhordása egyenletes barna erdőtalaj, bolygatásnak nincs nyoma (5. ábra). A halmon lévő fák mellett, erdei út érinti, az északkeleti szélén. A halom közepén húzott, kelet-nyugati irányú kutatóárok-

132 Melhárd 1882a, 151. A leletek a kaposvári múzeumba nem kerültek be. KÖH 19860. lelöhely.

133 RRM A. IV/60/2.

134 Csizmadia Gábor-Németh Péter Gergely ásatása. Ltsz: R.98.11.116. és R.2000.1.1-15. A halomsírokat, hasonlóan a többi feltáráshoz, az ásatás után, megpróbáltuk az eredeti állapot szerint viszszaállítani. Az 1.halom visszatemetésében a somogyjádi általános iskola tanulói is részt vettek, munkájukat ezúton is köszönjük. ból, vékony falú pohár töredékei, festett kancsó vagy korsó töredékei, nagyobb fazék aljtöredékei mellet, őskori és római kori kerámiatöredékek kerültek elő, valamint a kutatóárok északi részéről, $40 \mathrm{~cm}$ mélységből, meghatározhatatlan korú, kis bronztöredék. A kutatóárok közepén néhány hamv és kisebb faszéndarab is elökerült (XV. t. 4.).

A déli rész bontása a fák közötti részre korlátozódott. Beásásnak, sírgödörnek nincs nyoma, hamv nem került elő. A délnyugati részről a pohár további peremtöredéke mellett két kerámiatöredéket találtunk. A délnyugati részen a feltárás nem ért el a halom lábáig. A délkeleti részen a halom lábáig ástunk, több vékony falú római töredék mellett vastag falú őskori kerámiatöredékek is előkerültek.

Az északi részről, a halom felhordásában, vékony falú edénytöredékek mellett katonatál töredékeit, behajló peremtöredéket, vastag falú oldaltöredékeket, valamint egy pattintékot gyűjtöttünk. A halom északnyugati részéről, mintegy $50 \mathrm{~cm}$ sugarú körön belül, elszórva, Drag. 37-es tál töredékei kerültek elő. További bontás után újabb darabokat találtunk, a korábban előkerült darabokkal egyező mélységben, a halom északi részének közepén is.

A tanúfal bontásából, római kerámiatöredékek mellett, néhány őskori kerámiatöredék és állatcsonttöredék és mindössze egyetlen emberi hamv került elő. A tanúfal alatti rész bontásából föleg őskori kerámiatöredékek (egy orsógombtöredék is) és néhány római kori kerámiatöredék került elő. $A$ halom északi részének 
bontásából sok római kori kerámia mellett néhány őskori kerámia és egy pattinték, $50-80 \mathrm{~cm}$ mélységbõl három $\mathrm{db}$ emberi hamv került elõ.

$A z$ északnyugati negyedbõl, a halom felhordása alatti részből őskori (Dunántúli Vonaldíszes Kultúra) gödröt találtunk (1. objektum), az ívelt falú, egyenetlen aljú gödörbõl sok állatcsont és kerámiatöredék került elõ, ide tartoznak a halom felhordásában talált neolit cserepek is. Az őskori objektumon kívül szórványosan rézkori (Baden Kultúra) és késő bronzkori (Urnamezős Kultúra) kerámitöredékek is előkerültek.

A délnyugati negyedből néhány őskori kerámiatöredék és egy kőtöredék, a délkeleti negyedből kevés őskori kerámiatöredék mellett római edénytöredékek (pohártöredékek, szürke színü edény oldaltöredékei, festett korsó töredékei) és kevés emberi hamv kerültek elő. Mivel a kevés hamv és a néhány római edény töredékei teljesen elszórtak, a középen lévő fa alatti rész feltárását nem végeztük el.

A délkeleti negyed déli részén, ahol korábban néhány hamv mellett római edénytöredékek kerültek elő. További edénytöredékeket gyűjtöttünk egy bizonytalan körvonalú, ívelt aljú részről, melyet nem lehet sírgödörnek, vagy objektumnak nevezni, a leletek a halom feltöltésében voltak.

A hamvak és a római edénytöredékek föleg az eredetei felszínen kerültek elõ elszórva, a halom alatt nem volt sírgödör.

Mellékletek:

1. Edény töredékei

Szűknyakú korsó (?) 11 db töredéke, belül jól látható korongolás nyomokkal. Szürke. Néhány barna színü töredéknek az edényhez való tartozása kérdéses. Átlagos Fv: 0,7 cm. Ltsz: R.98.11.1. (X. t. 3.)

2. Oldaltöredék

Fésüsdíszes, ívelt, vastag falú töredék. Barnásszürke. H: 9,6 cm. Sz: $6 \mathrm{~cm}$. Fv: 1,2 cm. Ltsz: R.98.11.2.

3. Oldaltöredék

Keményre kiégetett, belül jól látható korongolás nyomokkal. Barna, belül szürke. $\mathrm{H}: 4,8 \mathrm{~cm}$. Sz: 4,9 cm. Fv: 0,8 cm. Ltsz: R.98.11.3.

4. Bronztöredék

Kis bronztöredék. H: $1,7 \mathrm{~cm}$. Sz: $1 \mathrm{~cm}$. Ltsz: R.98.11.4.

5. Pohár töredékei

Kihajló peremü, a perem alatt és a hason árkolásokkal. Szürke, több barna színű töredéken másodlagos égésnyom látszik, néhány töredéknek az edényhez való tartozása kérdéses. Átlagos Fv: 0,4 cm. Ltsz: R.98.11.5. (X. t. 4.)

6. Fazék töredékei

Kézi korongon készült, durva kidolgozású, kívül barna-szürke, belül fekete. Átlagos Fv: $0,7 \mathrm{~cm}$. Ltsz: R.98.11.6.

7. Edénytöredék

Belül jól látható korongolás nyomokkal, hastöredék (?), szürke színű. H: $4,5 \mathrm{~cm}$. Sz: $5,1 \mathrm{~cm}$. Fv: 0,8 cm. Ltsz: R.98.11.7.
8. Oldaltöredék

Ívelt töredék, belül jól látható korongolás nyomokkal. Szürke. H: 7,4 cm. Sz: 4,1 cm. Fv: 0,9 cm. Ltsz: R.98.11.8.

9. Oldaltöredék

Enyhén ívelt, porózus, kaviccsal durván soványított. Piros, belül sárga. $\mathrm{H}: 5,6 \mathrm{~cm}$. Sz: $5,4 \mathrm{~cm}$. Fv: 1,2 cm. Ltsz: R.98.11.9.

10. Terra sigillata tál töredékei Kihajló peremú, a perem alatt árkolt, alatta bordákkal tagolt tojásfüzérrel, majd rozettákkal és medalionokkal díszített. Pfaffenhofen-i mủhely terméke, Dicanus mesterhez köthetö. Készítési ideje: 3. század 3. harmada. (34 db.). Átlagos Fv: 0,6 cm. Ltsz: R.98.11.10. (X. t. 1a-e.)

11. Tál töredékei

Behajló, profilált peremmel, kívül-belül jól látható korongolás nyomokkal. Szürke-barna. Átlagos Fv: 0,7 cm. Ltsz: R.98.11.11. (X. t. 2.)

12. Edény töredékei

Kihajló peremű, nagyobb edény (korsó?) porózus, szürke színü töredékei $(74 \mathrm{db})$. A váll és a has találkozásánál árkolás fut körbe. Átlagos Fv: 0,5 cm. Ltsz: R.98.11.12.

13. Oldaltöredék

Hasonló anyagú töredék, esetleg az előző edény másodlagos megégésü darabja. Szürke, belül barna. H: 7,9 cm. Sz: $5 \mathrm{~cm}$. Fv: 0,6 cm. Ltsz: R.98.11.13.

14. Oldaltöredék

Ívelt, szürke színű töredék, esetleg Faltenbecher darabja. H: 4,1 cm. Sz: $2,5 \mathrm{~cm}$. Fv: 0,5 cm. Ltsz: R.98.11.14.

15. Oldaltöredék

Ívelt válltöredék, fésűsdíszes, szürke. $\mathrm{H}: 4,8 \mathrm{~cm}$. Sz: 2,2 cm. Fv: 0,5 cm. Ltsz: R.98.11.15.

16. Oldaltöredék

Ívelt, kopott, szürke, belül fekete. $\mathrm{H}: 4,1 \mathrm{~cm}$. Sz: 4,5 cm. Fv: 0,6 cm. Ltsz: R.98.11.16.

2. halom. Átmérője $106 \mathrm{~cm}$, magassága $52 \mathrm{~cm}$, bolygatásnak nincs nyoma, felhordása egyenletes barna erdőtalaj, a délkeleti részen, kisebb területen, sárga agyagos, az északi részén barna homok (XV. t. 3. és XIX. t. 3.).

A déli rész bontásából, 0-10 cm mélységből, őskori, egyenetlenül átégett edény töredékei, római kori, behajló peremű tál töredékei és egyéb római kori kerámiatöredékek kerültek elő. $10 \mathrm{~cm}$-től a halom aljáig néhány őskori edénytöredék, pattinték, római kerámiatöredékek mellett, rossz megtartású edény peremtöredéke került elő, utóbbi a délnyugati negyedből. A déli rész aljából néhány római kori kerámiatöredék került elő. A délnyugati részen és középen, nagyon kevés, elszórt faszén került elő.

Az északi részen, a halom felhordásában, kevés őskori és római kori kerámiatöredék volt (köztük porózus, finoman iszapolt árkolásokkal díszített edénytöredék), a halom északi részén, a halom aljánál minimális faszén került elő. Az északi részen, az erdei barna talaj alatt, 
egységes barna homok van, ezt mélyítettük, benne elszórva föleg őskori (Lengyel Kultúra?) kerámiatöredék került elö, a római cserepek között másodlagos átégésü peremtöredék, árkolt oldaltöredék, esetleg ugyanahhoz az edényhez tartozó fenéktöredék volt. A halom eredeti tetejétől mérve, $80 \mathrm{~cm}$ mélységben, elértük az altalajt.

A halom közepén, a déli részen is mélyítettük a barna réteget, hasonló mélységben itt is elértük az altalajt. Mindkét irányban (az északi és déli részen egyaránt) mélyítettük a barna réteget, őskori cserepek kerültek elő, főleg a halom közepénél.

Folytattuk a barna réteg bontását, sírgödör nem került elő. Bár a halom alatt teljes szélességben nem ástuk le az altalajig a barna réteget, sírgödör előkerülésére nem volt remény. $A$ barna rész kiterjedését, mely tulajdonképpen az őskori „járószint”, a sírrajzon rögzítettük.

Mellékletek:

1. Edény töredékei

Kihajló peremü, profilált, szürke. $\mathrm{H}: 5,3 \mathrm{~cm}$. Sz: $3,9 \mathrm{~cm}$. Fv: 0,6 cm. H: 7,3 cm Sz: $6 \mathrm{~cm}$. Fv: 0,5 cm.Ltsz: R.2000.1.1. (X. t. 9.)

2. Oldaltöredék

Hasonló töredék, esetleg az előző edény darabja. H: 4,1 cm Sz: 3,9 cm. Fv: 0,5 cm. Ltsz: R.2000.1.2.

3. Fedő töredék

A fogórész töredéke. Világosszürke. $\mathrm{H}: 3,5 \mathrm{~cm} \mathrm{Sz}$ : 1,6 cm. Ltsz: R.2000.1.3.

4. Oldaltöredék

Ívelt, profilált, szürke.H: 4,1 cm Sz: 2,1 cm. Fv: 0,4 cm. Ltsz: R.2000.1.4.

5. Tál töredékei

Behajló peremü, porózus, sárgásbarna. $\mathrm{H}: 6,1 \mathrm{~cm}$ Sz: $4,8 \mathrm{~cm}$. Fv: 0,8 cm. H: $6,1 \mathrm{~cm}$. Sz: $4,9 \mathrm{~cm}$. Fv: $0,8 \mathrm{~cm}$. Ltsz: R.2000.1.5. (X. t. 5.)

6. Fazéktöredék

Nagyobb edény fenéktöredéke. Porózus, világosszürke. Átmérő: $13,1 \mathrm{~cm}$. Fv: $0,7 \mathrm{~cm}$. Ltsz: R.2000.1.6

7 Fazéktöredék

Kihajló peremtöredék. Szürke. H: 2,6 cm Sz: 2,2 cm. Fv: 0,4 cm. Ltsz: R.2000.1.7. (X. t. 8.)

8. Edénytöredék Kihajló peremü, ívelt oldalú töredék. Szürke. H: 2,6 cm Sz: 2,6 cm. Fv: 0,5 cm. Ltsz: R.2000.1.8. (X. t. 7.)

9. Oldaltöredék

Enyhén ívelt, vékonyfalú, hullámvonallal díszített. Szürke. H: $3 \mathrm{~cm} \mathrm{Sz:} \mathrm{1,8} \mathrm{cm.} \mathrm{Fv:} \mathrm{0,3} \mathrm{cm.} \mathrm{Ltsz:}$ R.2000.1.9.

10. Oldaltöredék

Ívelt, porózus, szürke. H: $3,6 \mathrm{~cm} \mathrm{Sz:} 2,9 \mathrm{~cm}$. Fv: 0,3 cm. Ltsz: R.2000.1.10.

11. Oldaltöredék

Kaviccsal soványított, szürke. H: $2,8 \mathrm{~cm}$ Sz: 2,1 cm. Fv: 0,3 cm. Ltsz: R.2000.1.11.

12. Oldaltöredék Ívelt, vékonyfalú, bordadíszes oldaltöredék. Porózus, sárga. H: $3,2 \mathrm{~cm}$ Sz: $2,5 \mathrm{~cm}$. Fv: 0,3 cm. Ltsz: R.2000.1.12.
13. Oldaltöredék

Ívelt, kopott, szürke. H: 4,2 cm Sz: 4,3 cm. Fv: 0,6 cm. Ltsz: R.2000.1.13.

14. Oldaltöredék

Ívelt, kopott, világosszürke, belül jól látható korongolás nyomokkal. H: $3,2 \mathrm{~cm} \mathrm{Sz:} \mathrm{4,8} \mathrm{cm.} \mathrm{Fv:} \mathrm{0,5} \mathrm{cm.}$ Ltsz: R.2000.14.1.

15. Edénytöredék

Behajló peremtöredék másodlagos égésnyomokkal. Barka-szürke. $\mathrm{H}: 3 \mathrm{~cm} \mathrm{Sz:} \mathrm{3,4} \mathrm{cm.} \mathrm{Fv:} \mathrm{0,6} \mathrm{cm.}$ Ltsz: R.2000.1.14. (X. t. 6.)

16. Oldaltöredék

Enyhén ívelt, szürke. H: 2,6 cm Sz: 1,8 cm. Fv: 0,3 cm. Ltsz: R.2000.1.15.

Miután a somogyjádi mellékletek töredékesen kerültek a halmok földjébe, több esetben az edények elkülönítése is nehézséget okoz. Számos kerámiatöredéken figyelhető meg másodlagos égésnyom, ezek a halotti máglyáról származtak. A tárgyak döntő része jól korongozott, helyenként árkolással és bordadísszel, hullámvonallal és fésüléssel díszített. Korsóhoz tartozhatott több töredék (X. t. 3.) és hasonló edény lehetet az 1. halom 12. melléklete is. Az utóbbi edényen árkolás fut körbe. A töredékes pohár (X. t. 4.) párhuzamát a söjtöri 7 . halom edényében látjuk ${ }^{135}$ és így az 1-2. századra keltezhetjük. Mindkét somogyjádi halomban került elő katonatányér töredéke, melyek már a 2. században készülhettek. ${ }^{136} \mathrm{~A}$ terra sigillata tál (X. t. 1a-e.) már a 3. század 3. harmadában készült. Ez alapján, legalábbis az 1 . halom esetében, rendkívül késői temetkezésről van szó.

A halmoktól keletre, az erdő szélénél, az Apánkaalján, néhány római kerámiatöredék került elő terepbejárás során. ${ }^{137}$

1. Edénytöredék

Kihajló peremű, enyhén ívelt, árkolt. Szürke, fekete festés nyomaival. $\mathrm{H}: 4,1 \mathrm{~cm}$. Sz: 4,1 cm. Fv: 0,6 cm. Ltsz: R.98.12.1. (I. t. 8.)

2. Peremtöredék

Kihajló, levágott peremű, a nyakon árkolások futnak körbe, kékesszürke. H: $4 \mathrm{~cm}$. Sz: 1,9 cm. Fv: 0,8 cm. Ltsz: R.96.4.1.

3. Aljtöredék

Alacsony talpgyürüs töredék. Barna, fekete festés nyomaival. $\mathrm{H}: 4,4 \mathrm{~cm}$. Sz: 2,1 cm. Fv: 0,4 cm. Ltsz: R.98.12.2.

Az Apánka-aljától keletre, egy dél-északi irányú vízfolyás és a vasút között, a Varsalik-dülöben, kis területen szétszórva, római épülettörmelék található, esetleg kisebb villa meglétére utal. Terepbejárás során 2-4. századi leleteket gyűjtöttünk. ${ }^{138}$

135 Horváth 2000, 238. és 10 . kép.

136 Palágyi - Nagy 2000, 120.

137 Németh Péter Gergely terepbejárása 1986. RRM A. 177. Ltsz: R.98.4.1. és R.98.12.1-2.

138 Németh Péter Gergely leletmentése 1986. és Csizmadia GáborNémeth Péter Gergely terepbejárása, 1993. RRM A. 177. és 602. KÖH 19883. lelőhely. Ltsz: R.96.3.1-15. és R.98.12.3-6. 
1. Terra sigillata tál töredéke

Drag. 37 tál peremtöredéke, narancssárga. Rheinzaberni műhely, késő Antoninus-Severus-kor. $\mathrm{H}: 5 \mathrm{~cm}$. Sz: 2,6 cm. Fv: 0,6 cm. Ltsz: R.96.3.6. (I. t. 4.)

2. Táltöredék Behajló peremü, porózus, okkersárga. $\mathrm{H}: 5,7 \mathrm{~cm}$. Sz: 3,3 cm. Fv: 0,7 cm. Ltsz: R.96.3.1. (I. t. 6.)

3. Peremtöredék

Behajló, profílált peremü, kékesszürke. $\mathrm{H}: 2,7 \mathrm{~cm}$. Sz: $3,3 \mathrm{~cm}$. Fv: 0,6 cm. Ltsz: R.96.3.2.

4. Aljtöredék

Nagyobb edény aljtöredéke, finoman iszapolt, barna. H: $5,4 \mathrm{~cm}$. Sz: $3,9 \mathrm{~cm}$. Fv: 0,7 cm. Ltsz: R.96.3.3.

5. Oldaltöredék

Belül jól látható korongolás nyomokkal, kopott, porózus, világosszürke. $\mathrm{H}: 3,7 \mathrm{~cm}$. Sz: $3,8 \mathrm{~cm}$. Fv: 0,6 cm. Ltsz: R.96.3.4.

6. Fedő peremtöredéke

Jól korongolt, csillámos felszínü, fekete. $\mathrm{H}: 5,2 \mathrm{~cm}$. Sz: $3,8 \mathrm{~cm}$. Fv: 0,5 cm. Ltsz: R.96.3.7.

7. Oldaltöredék Ívelt, kopott, barna, narancssárga festéssel. $\mathrm{H}: 1,5$ cm. Sz: 1,2 cm. Fv: 0,2 cm. Ltsz: R.96.3.8.

8. Peremtöredék

Kihajló peremü, simított, világosbarna. $\mathrm{H}: 2,1 \mathrm{~cm}$. Sz: 1,6 cm. Fv: 0,3 cm. Ltsz: R.96.3.9.

9. Oldaltöredékek Különböző edények díszítetlen töredékei. Porózus, okkersárga. H: 3,7 cm. Sz: 2,2 cm. Fv: 0,5 cm. H: $3,7 \mathrm{~cm}$. Sz: 3,7 cm. Fv: 0,7 cm. Ltsz: R.96.3.10.

10. Fazéktöredék

Kihajló, vízszintes, árkolásokkal díszített peremmel. Kaviccsal soványított, kékesszürke. $\mathrm{H}$ : $4 \mathrm{~cm}$. Sz: 3,9 cm. Fv: 1,3 cm. Ltsz: R.96.3.11.

11. Oldaltöredékek

Különböző edények seprüdíszes töredékei. Szürke, illetve barna. Átlagos Fv: 0,9 cm. Ltsz: R.96.3.1213. és R.98.12.6.

12. Aljtöredékek

Különböző edények aljtöredékei, az egyik darab hasán seprődísz. Kékesszürke. H: $3,7 \mathrm{~cm}$. Sz: 3,8 $\mathrm{cm}$. Fv: $1,2 \mathrm{~cm}$, illetve H: 4,4 cm. Sz: 4,1 cm. Fv: 0,6 cm. Ltsz: R.96.3.14-15.

13. Peremtöredék

Nagyobb edény kihajló töredéke, sávos simítású, világosszürke. H: 6,5 cm. Sz: 4,2 cm. Fv: $1 \mathrm{~cm}$. Ltsz: R.98.12.3.

14. Aljtöredékek

Különböző edények talpgyűrüs, világosszürke színü töredékei. $\mathrm{H}: 3,8 \mathrm{~cm}$. Sz: $3,5 \mathrm{~cm}$, illetve $\mathrm{H}: 5,7$ cm. Sz: 4,2 cm. Fv: 0,5 cm. Ltsz: R.98.12.5

15. Tegula töredéke

Tegula peremtöredéke, sárga. $143,7 \times 7,3 \mathrm{~cm}$. M: $4,7 \mathrm{~cm}$. A perem M: 1,8 cm. Ltsz: R.96.3.5.

16. Érme

330-341. között vert constantinopolisi érme, Ae3. ${ }^{139}$

139 Torbágyi Melinda meghatározását ezúton is köszönjük. Numizmatikai Gyűjtemény. Ltsz: 2015.9.1.
A Varsalik-dűlőtől északra, a Hegy-erdőn, néhány jellegtelen római kori kerámiatöredék gyűjthető. ${ }^{140}$

A Varsalik-dülőtől északnyugatra, a Dalai-dűlőben, nagy területről, sok őskori és kevés római kori lelet gyüjthető. ${ }^{141}$

1. Tál töredéke

Behajló peremtöredék. Sárga anyagú, téglavörös mázzal. Kiszerkesztett Szá.: 13,4 cm. Fv: 0,5 cm. Ltsz: R.96.6.1. (I. t. 7.)

2. Fazék töredéke

Fazék vágott, vastag peremtöredéke. A perem külső oldalán árkolás látható. Szürke, kaviccsal soványított. Kiszerkesztett Szá: 24 cm. Ltsz: R.96.6.2.

3. Fazék töredéke

Kihajló, vízszintes peremtöredék. Kaviccsal soványított, kékesszürke. 4 x 3,1 cm. Fv: 0,6 cm. Ltsz: R.98.6.3. (I. t. 5.)

4. Fazék töredéke Kihajló, levágott peremmel, világosszürke. H: 3,8 cm. Sz: 2,5 cm. Fv: 0,3 cm. Ltsz: R.98.12.9. (I. t. 3.)

5. Oldaltöredék

Ívelt, seprüdíszes töredék, barna. $\mathrm{H}: 6 \mathrm{~cm}$. Sz: 3,7 cm. Fv: 0,4 cm. Ltsz: R.98.12.10.

Az Apánkai-erdőtől északra, kb. 1200 m-re, római téglasír került elő, leletei nem jutottak be a kaposvári múzeumba, valószínűleg a késő római korba tartozott. ${ }^{142} \mathrm{~A}$ sír előkerülési helye és az Apánkai-erdő között, a Szőlőhegy-alja nevű dűlőn, szórvány, jellegtelen római peremtöredék került elő terepbejárás során. ${ }^{143}$

\section{Somogyvár - Bréza-erdó}

Szegvári Zoltán természetvédelmi felügyelő (Duna-Dráva Nemzeti Park) bejelentése nyomán, $M$. Aradi Csilla és Jankovich-Bésán Dénes halomsírokat azonosított. ${ }^{144}$ 2007-ben próbafeltárást végeztünk a kelet-nyugati irányú, nyolc halmot magába foglaló temető korának, valamint a rablottság szintjének megállapítása miatt (6. ábra és XII. tábla). Két halmot kutatóárokkal vizsgáltunk meg, mindkettő szerkezete azonos volt, koruk római kori. Mindkét halom közepén helyzeték el a hamvakat, egy-egy edény szétszórt töredékeivel. Megvizsgáltunk egy harmadik, csaknem teljesen elhordott halmot is.

1. halom. Átmérője: $725 \mathrm{~cm}$, magassága $136 \mathrm{~cm}$. Bolygatásnak nincs nyoma, közepén nagyobb fa állt. 2 $m$ széles kutatóárokkal vizsgáltuk át, a halom közepén ezt déli irányban, kissé kibővítettük (XVI. t. 1. és XX. t. 1.). Öskori kerámiatöredék mellett, római kori edénytö-

140 Németh Péter Gergely terepbejárása, 1986. RRM A. 177. KÖH 19885. Ltsz: R.98.12.7-8

141 Németh Péter Gergely terepbejárása, 1986. RRM A. 177. KÖH 19886. Ltsz: R.96.6.1-3. és R.98.12.9-10

142 RRM A. IV/60/6. és Draveczky 1965. 7I. KÖH 19948. lelőhely.

143 Csizmadia Gábor-Németh Péter Gergely terepbejárása, 1993. RRM A. 602. Ltsz: R.96.5.1.

144 RRM A. 2461. KÖH 44355. lelöhely. Szegvári Zoltán bejelentését ezúton is köszönjük. 


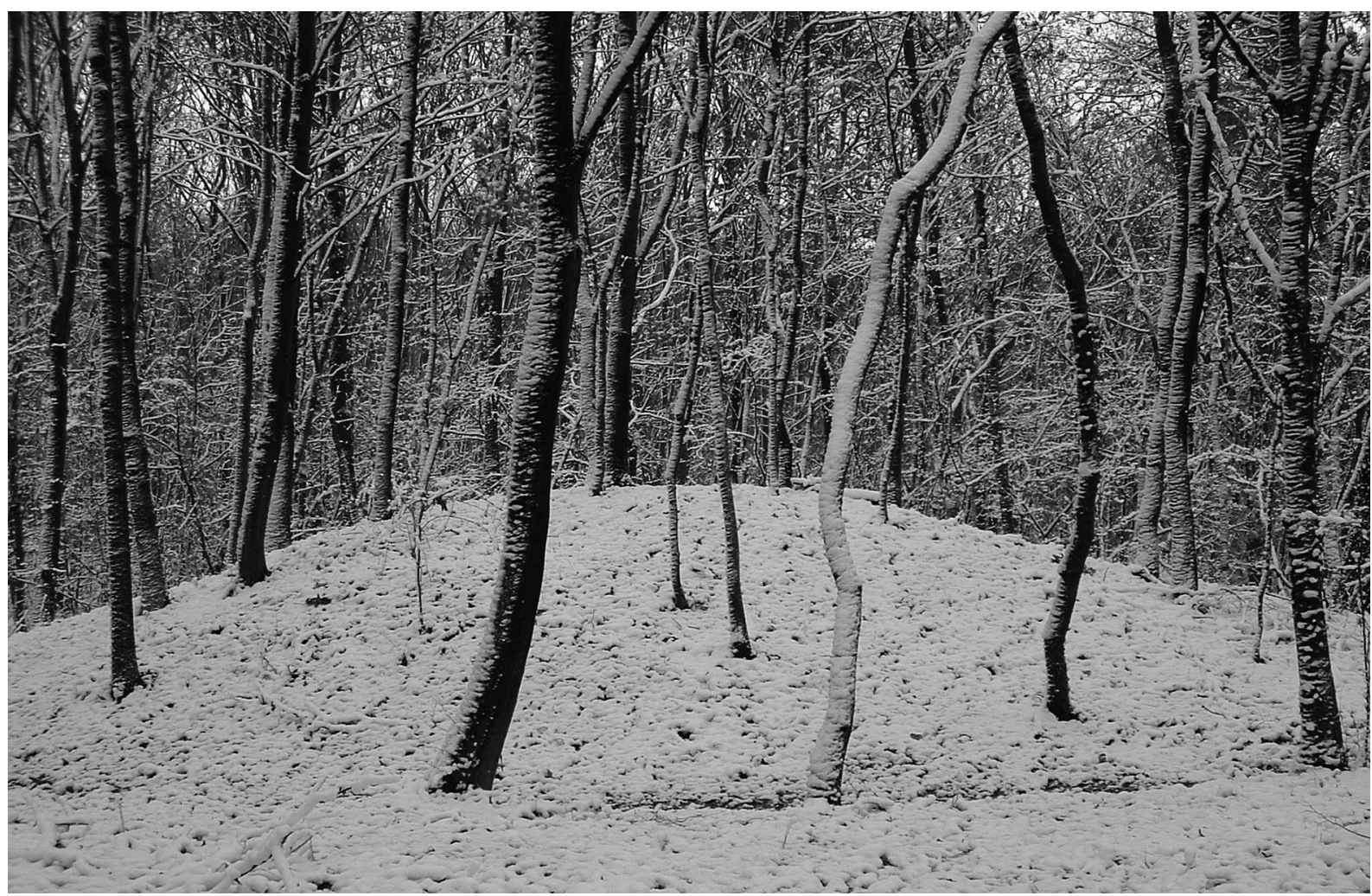

6. ábra. Halomsír a somogyvári temetőben

redékek kerültek elő. A halom közepén több, apró kalcinált embercsont és minimális faszén került elő, sírfolt nem volt megfigyelhető. A kutatóárok déli rábontásában kevés hamv és római kori edénytöredék volt. A fentiek alapján szórthamvas rítusú temetkezés volt, kevés hamvval, minimális faszénnel és egy edényhez tartozó edénytöredékkel, melyet a sír közepén elszórtak.

\section{Mellékletek:}

1. Fazék töredékei

Kihajló, vízszintes peremü fazék részben öszszeillő töredékei (14 db). Fésült díszes, kaviccsal sürün soványított, szürke. Átl. Fv: $0,3 \mathrm{~cm}$. Ltsz: R.2005.6.1. (XII. t.).

2. Kőtöredék

Sötétszürke színü, erezett kőtöredék. H: $6 \mathrm{~cm}$. Sz: 3 cm Ltsz: R.2005.6.2.

2. halom. Átmérője: $750 \mathrm{~cm}$, magassága $90 \mathrm{~cm}$, bolygatásnak nincs nyoma. $2 \mathrm{~m}$ széles kutatóárokkal vizsgáltuk át, a halom közepén ezt nyugati irányban, kissé kibővítettük (XVI. t. 2. és XX. t. 2.). A kutatóárokban, a halom közepén, kevés hamv és néhány római kori kerámiatöredék került elő. A halom közepén sekély, nagyjából kerek, meredek falú, teknős aljú gödör volt, benne kevés hamv, több faszén és római kori edény további töredékei. Kevés hamv és 1-2 kerámiatöredék a sírgödör mellett is volt.
Mellékletek:

1. Edény töredékei

Kihajló, felül árkolt peremü, alacsony talpgyürüs edény részben összeillö töredékei $(16 \mathrm{db})$. Porózus, szürke, barna festés nyomaival. Átl. Fv: 0,2 cm. Ltsz: R.2005.6.3. (XII. t.)

3. halom. Átmérője: $850 \mathrm{~cm}$. A csaknem teljesen szétásott halom közepét ástuk ki, hogy az esetleges, elszórt leleteket összegyüjtsük, vagy a temetkezés szerkezetét megállapítsuk (XVI. t. 3. és XX. t. 3.). A felső $10 \mathrm{~cm}$-ben állatcsont (valószínüleg jelenkori), kevés homokkődarab és egy őskori őrlőkő töredék volt. A humusz alatt homok és helyenként barna erdőtalaj volt, sok, de apró kőtöredékkel és 1-2 római kori téglatöredéket is találtunk. A halom közepén sötét folt jelentkezett, ezt kibontottuk, kevés kőtöredék került elő. A gödör szélét nem bontottuk ki teljesen, fala meredek, alja egyenetlen, a gödörben sok fagyökér volt, a sír kirablása ez alapján nem a közelmúltban kerülhetett sor. A gödör nem tekinthető sírgödörnek, hanem a rablás nyoma. A kőtöredékek nem épített sírkamrára utalnak (habarcsot nem lehetett megfigyelni). A téglatöredékek alapján római korinak tekinthető halom kőborításos lehetett. 
Mellékletek:

1. Téglatöredék

Szabálytalan, világosbarna színü töredék. H: 6,5 cm. Sz: 4,8 cm Ltsz: R.2005.7.4.

2. Téglatöredék

Szabálytalan, barna-fehér színü töredék. A sír közepén lévő gödörből került elő. $\mathrm{H}: 7,6 \mathrm{~cm}$. Sz: 6,7 cm Ltsz: R.2005.7.7.

3. Kötöredékek

Szürke színű homokkőtöredékek ( $5 \mathrm{db}$ ). Néhány töredéken talán megmunkálás nyomok látszanak. Átlagos H: 6 cm. Átlagos Sz: 3 cm Ltsz: R.2005.7.1-3. és 7.5-6.

Az 1. és 2. halomból előkerült leletek, mindkét esetben, egy-egy edényhez tartoztak. Az 1. halom fazeka (XII. t.) az 1. és 2. század fordulójára keltezhető. ${ }^{145} \mathrm{~A} 2$. halom kerámiatöredékei valószínüleg egy kihajló peremü, talpgyürüs tálhoz tartoztak (XII. t.).

2009-ben bejártuk a Bréza- erdőt, de újabb halmokat nem találunk. ${ }^{146} \mathrm{~A}$ halomsíroktól nyugatra, nagykiterjedésű római kori telep van. Ugyanitt késő római villa és temető is megtalálható. ${ }^{147} \mathrm{~A}$ Somogyvártól délre lévő Pamuk község területén, római kori telepeket és szórványleleteket ismerünk. ${ }^{148}$

A biztosan római kori halomsíros temetkezések felmérése és a fennmaradt leírások alapján elmondhatjuk, hogy jellemző a temetőkre a kelet-nyugati irány. Kitűnik az is, hogy a temetőkön belül egy-egy nagyobb halom köré csoportosulnak a kisebb halmok.

A római kori halomsírok felmérése és szondázó ásatásai mellett igyekeztünk a környezetüket is felderíteni. A legtöbb esetben a temetőkhöz tartozó telepek felderítése is megtörtént. Alsóbogáton az egész település bejárása megtörtént, a római halmok esetében még a közeli Somogygeszti területén célszerü bejárásokat végezni, egy esetleges telep felderítésére. Somogyaszalón, a temetőtől nyugatra, feltételezhető villa, keletre kisebb telep található. Somogyjádon a halmoktól keletre több telep és egy esetleges épület is található. A nyugati irányban, a közeli Csombárd és Hetes települések területén, a bejárás még nem teljes körü. Somogyváron, a halmoktól nyugatra, több telepet is ismerünk és egy villa feltárása is megtörtént. Orciban nincs tudomásunk római kori telepről, de itt az egykori temető pontos helye is bizonytalan. Nagyberki esetében pedig a szalacskai földvár területén találjuk meg a római kori települést.

\footnotetext{
145 Palágyi - Nagy 2000, 109.

146 Németh Péter Gergely terepbejárása. RRM A. 2632.

147 Somogyvár-Resterica I.-II. és IV. lelöhely (KÖH 47994., 47997. és 56927.).

148 Pamuk-Pészka, Rákóczi úti hídtól K-re, és Gál-horog lelőhely (KÖH 48004., 48003. és 48006.)
}

Az Alsóbogát közelében lévő, feltételezett utak meglétét, időközben revideálnunk kellett, a biztos római halomsíros temetők esetében továbbra is gyanakodhatunk egy kisebb rangú út meglétére. A Nagyberki - Orci - Somogyaszaló - Alsóbogát - Somogyjád és

Somogyvár határában lévő halmok és a hozzájuk tartozó telepek, villák egy, ma még pontosan fel nem felderített út mellett helyezkedhettek el. Ezt kiegészítheti a még, ásatás híján nem ismert korú halomsíros temetők kutatása. Teljes biztonsággal akkor lehetünk, ha a bizonytalan keltezésű temetőkben, valamint a már ismert római kori temetőkhöz tartozó telepeken is lenne hitelesítő ásatás. A Pécs-Ságvár út mellett lehettek a már elpusztult Iregszemcse - csehipusztai halmok.

A Somogy megyei római kori halomsíros temetkezések az 1. és a 2. század fordulóján indulnak és a 2-3. században folytatódnak. A legkésőbbi temetkezést a somogyjádi 1 . halomban találjuk, mely a 3 . század 3 . harmadára keltezhető. Természetesen szükség volna újabb halom feltárásokra, hogy pontosabb képet nyerjünk. Szükséges volna a korábbi méréseket is pontosítani, ma már a technikai feltételek jóval kedvezőbbek. A 2015. évi, alsóbogáti helyszínelés megmutatta, hogy az erdőművelés megváltozása, vagyis az erdő rendezése, kitisztítása után újabb halmokat lehet felfedezni, még egy korábban felmért temetőn belül is. A felméréseket célszerü volna az őskori temetőkre is kiterjeszteni. A bizonytalan datálású halomsíros temetők esetében feltárásokkal kellene a keltezést tisztázni. 


\section{Irodalom}

BóNIS É. 1942: A császárkori edényművesség termékei Pannoniában (A Tera Sigillátákon kívül) I. A korai császárkor anyaga. Dissertationes Pannoniae II. 20.

Sz. BuRger A. 1966: A kékesdi koracsászárkori temető. Archaeológiai Értesítő 93: 254-271.

CsizmadiA G. \& NÉmeth P. G.: 1997. Roman Barrows in County Somogy. In: Balácai Közlemények V: 43-47.

CsizmAdiA G. és NÉmetH P. G. 2000: Római halomsíros temetők Somogy megyében. In: K. Palágyi Sylvia-Nagy Levente: Római halomsírok a Dunántúlon. Veszprém. 225-232.

DRAVECZKY B. 1965: Felfedező ásóval Somogyban II. Somogyi Szemle 66-76.

GÁBLI C. 2004: A firmamécsesek feldolgozásának új módszere. Panniculus Ser. A. No. 1. Szombathely.

HoNTI Sz. 1996: Ein Spätbronzezeitliches Hügelgrab in SávolyBabócsa. Pápai Múzeumi Értesítő (Acta Musei Papensis) 6: 235-248.

HoRVÁTH L. 2000: Újabban feltárt római kori halomsírok Zalában (Katalógus). In: K. Palágyi Sylvia-Nagy Levente: Római halomsírok a Dunántúlon. Veszprém. 233-253.

IPOLYI A. 1861: Magyar Régészeti repertórium. Archaeológiai Közlemények II: 294

IVÁNYI D. 1935: Die pannonischen Lampen. Dissertationes Pannoniae II. 2 .

M. KABAY É. 1960: A szalacskai koravaskori tumulusok anyaga a Magyar Nemzeti Múzeumban. Folia Archaeologica XII: 46-59.

KEMENCZEI T. 1974: Újabb leletek a nagyberki-szalacskai koravaskori halomsírokról. Archaeológiai Értesítő 101: 3-16.

KEMENCZEI T. 1975: Beszámoló a nagyberki-szalacskai 1974. évi ásatásról. Somogyi Műzeumok Közleményei 2: 163-171.

KEMENCZEI T. 1976 - Früheisenzeitliche Keramikfunde von Nagyberki. Folia Archaeologica XXVII: 203-208.

KoczTUR É. 1964: Somogy megye régészeti leletkatesztere. Régészeti Füzetek II/13.

V. Kocztur É. 1991: Kora császárkori temető Solymáron. Studia Comitatensia 21: 171-334.

KUZsıNSZKı B. 1920: A Balaton környékének archaeológiája. Budapest.

LACZKó D. 1912: Római telepnyomok és útirányok Veszprémmegye déli felében. In: Balácza. Veszprém 5-30.
LÁZÁR J. 1956: A magyarországi korai vaskor történetének kérdései. Antik Tanulmányok III: 1-22.

MAGYAR K. és NovÁKı GY. 2005: Somogy megye várai a középkortól a kuruc korig. Kaposvár.

MARÓTIÉ. 1987: Római kori bepecsételt kerámia Nyugat-Pannoniában. Zalai Múzeum 1: 81-127.

MELHÁRD GY. 1882: Néhány Somogy megyei körsáncos őshalomról. Somogyvármegyei Régészeti s Történeti Társulat Évkönyve 1879-1881. Kaposvár, 41-49.

MELHÁRD Gy. 1882a: A somogyvármegyei régiségtár köréből. Somogyvármegyei Régészeti s Történeti Társulat Évkönyve 1879-1881. Kaposvár, 50-61.

MELHÁRD GY. 1900: A nagyberki (Somogy m.) leletröl. Archaelógia Értesítő 20: 386-390.

K. PALÁgyI S. és NAGY L. 2000: Római halomsírok a Dunántúlon Veszprém.

S. K. PALÁGYI \& L. NAGY 2002: Römerzeitliche Hügelgräber in Transdanubien (Ungarn). Budapest.

PALÁGYI S. 2014: A sikátori kora császárkori temető. Laczkó Dezső Múzeum Évkönyve 28: 95-227.

RómER F. 1878: Résultats Généraux Mouvement du Archéologique en Hongrie. Budapest.

SÁGI K. 1943: Császárkori tumulusok Pannóniában. Archaelógiai Értesítő 113: 113-143.

SÁGI K. és CsÉBY G. 1990: Balatonszemesi régészeti emlékei. In. Szemes. Tanulmányok Balatonszemes múltjából és jelenéből. Szerk.: Stirling János. Balatonszemes, 59-84

SZEGVÁRI Z. 2003: Erdővel borított római kori halomsírmezők Somogyban. Kézirat.

WeSSETZKY V. 1983 - Thot majom szobrocskája Somogy megyéböl. Somogyi Múzeumok Közleményei 6: 5-11.

WosıNSZKY M. 1896: Tolna vármegye az őskortól a honfoglalásig. Budapest.

Somogy Megye Földrajzı NeVei. Szerk.: Papp László és Végh József. Budapest, 1974 


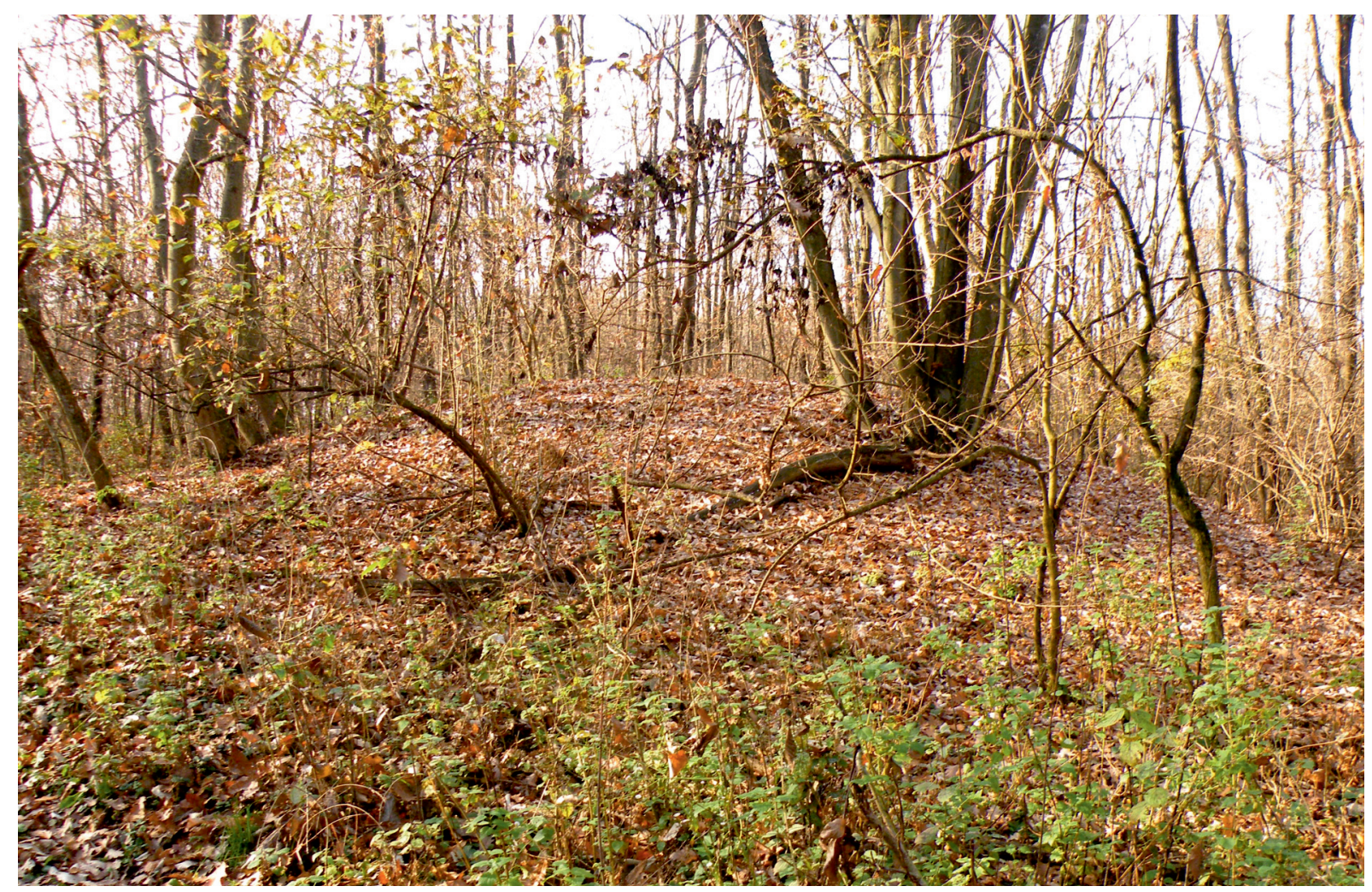

7. ábra. Alsóbogát - Csollányosi-erdő

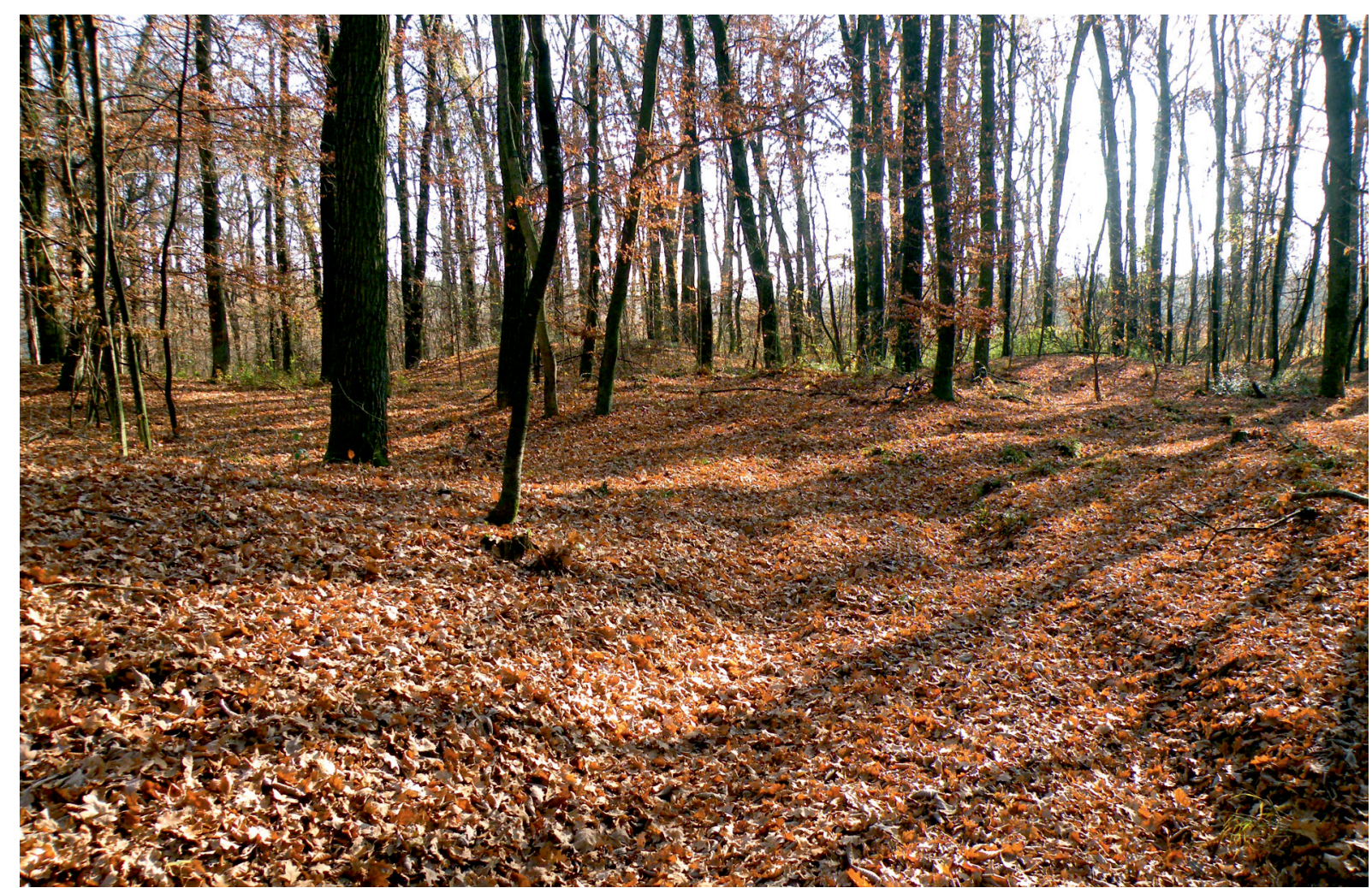

8. ábra. Somogyaszaló - Deseda-erdő 


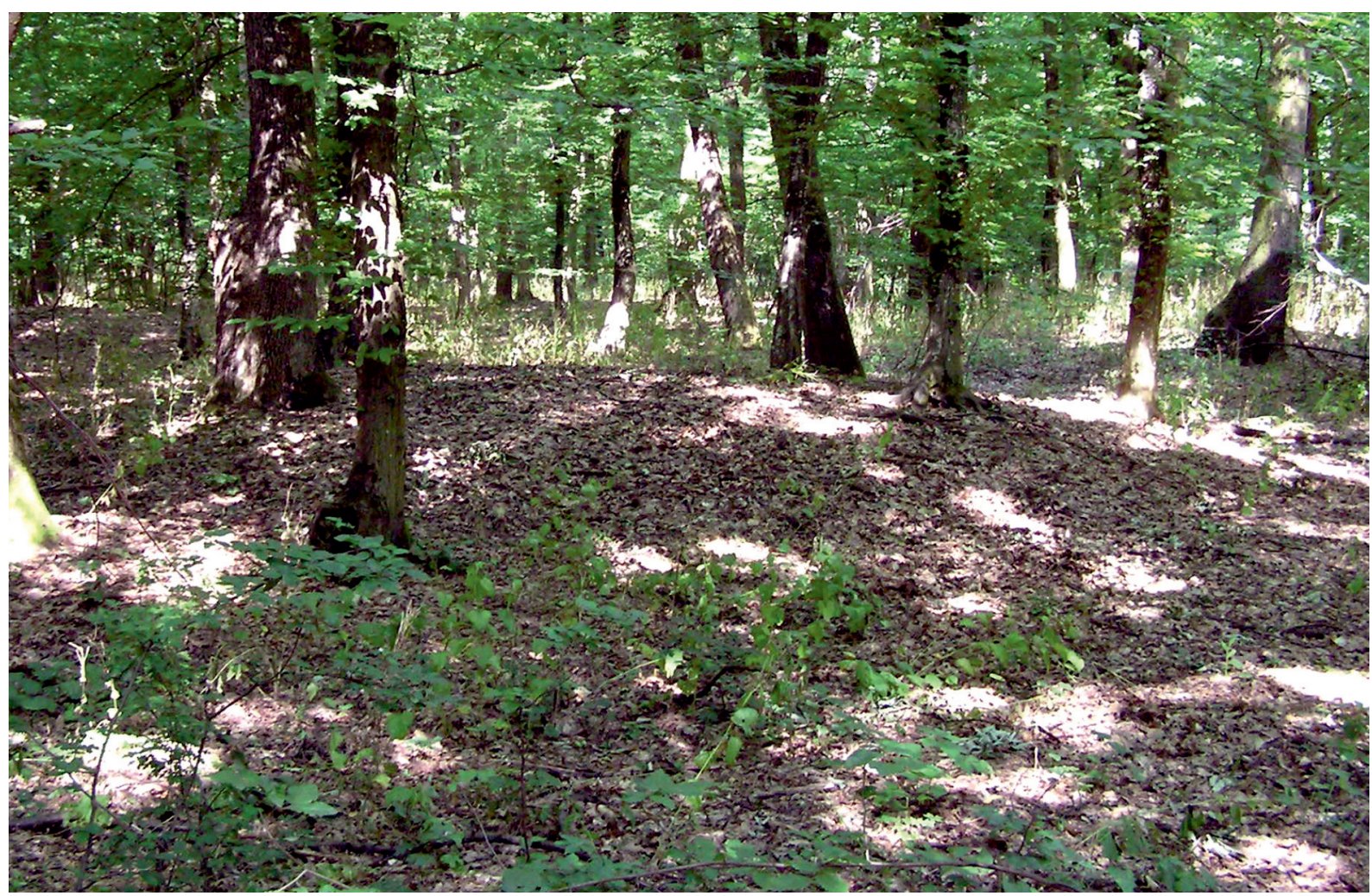

9. ábra. Somogyjád - Apánkai-erdő

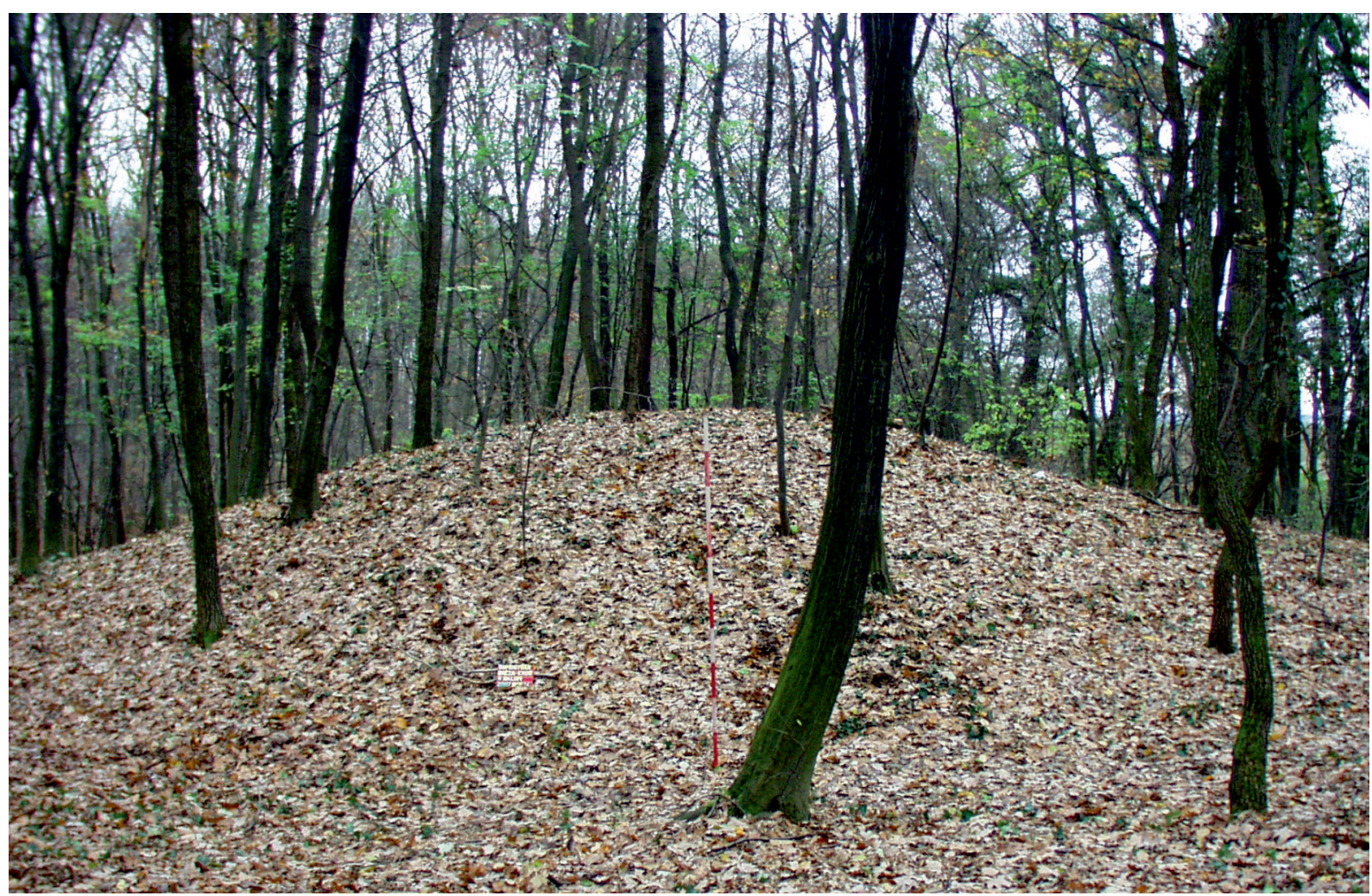



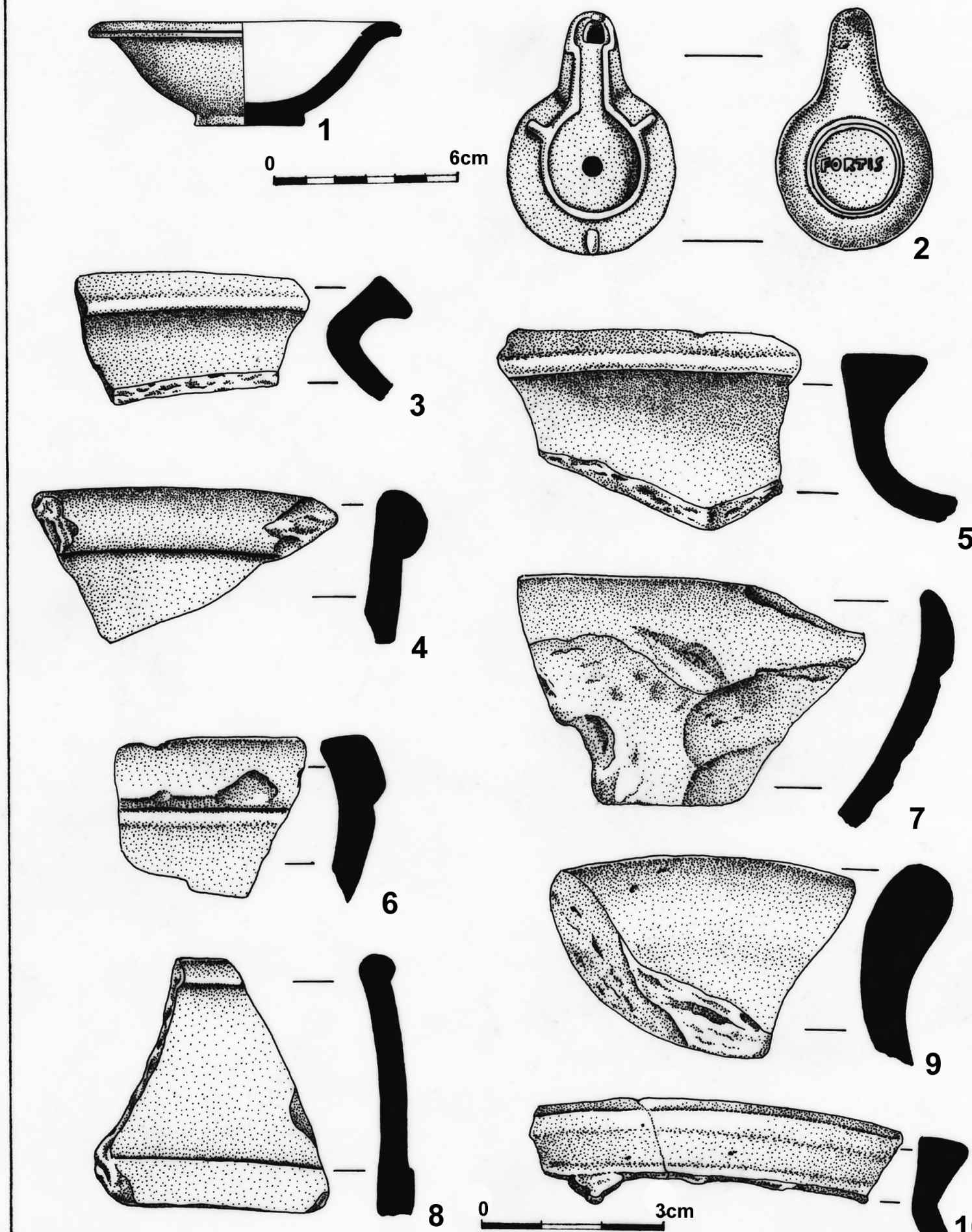

80
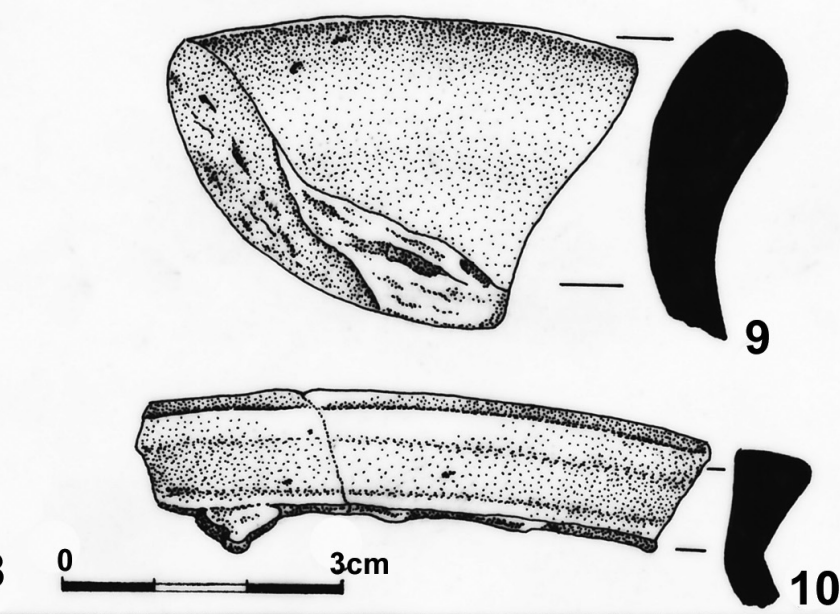

I. tábla. 1-2a-b. Orci, 3. 5. és 7. Somogyjád-Dalai-dülö, 4 és 6. Somogyjád-Varsalik, 8. Somogyjád-Apánka-alja, 9. Balatonszabadi-Siómaros-Sióbozót, 10. Juta-Gombosi-erdő. 1-2 M:1:1, 3-10. M: 1:1 


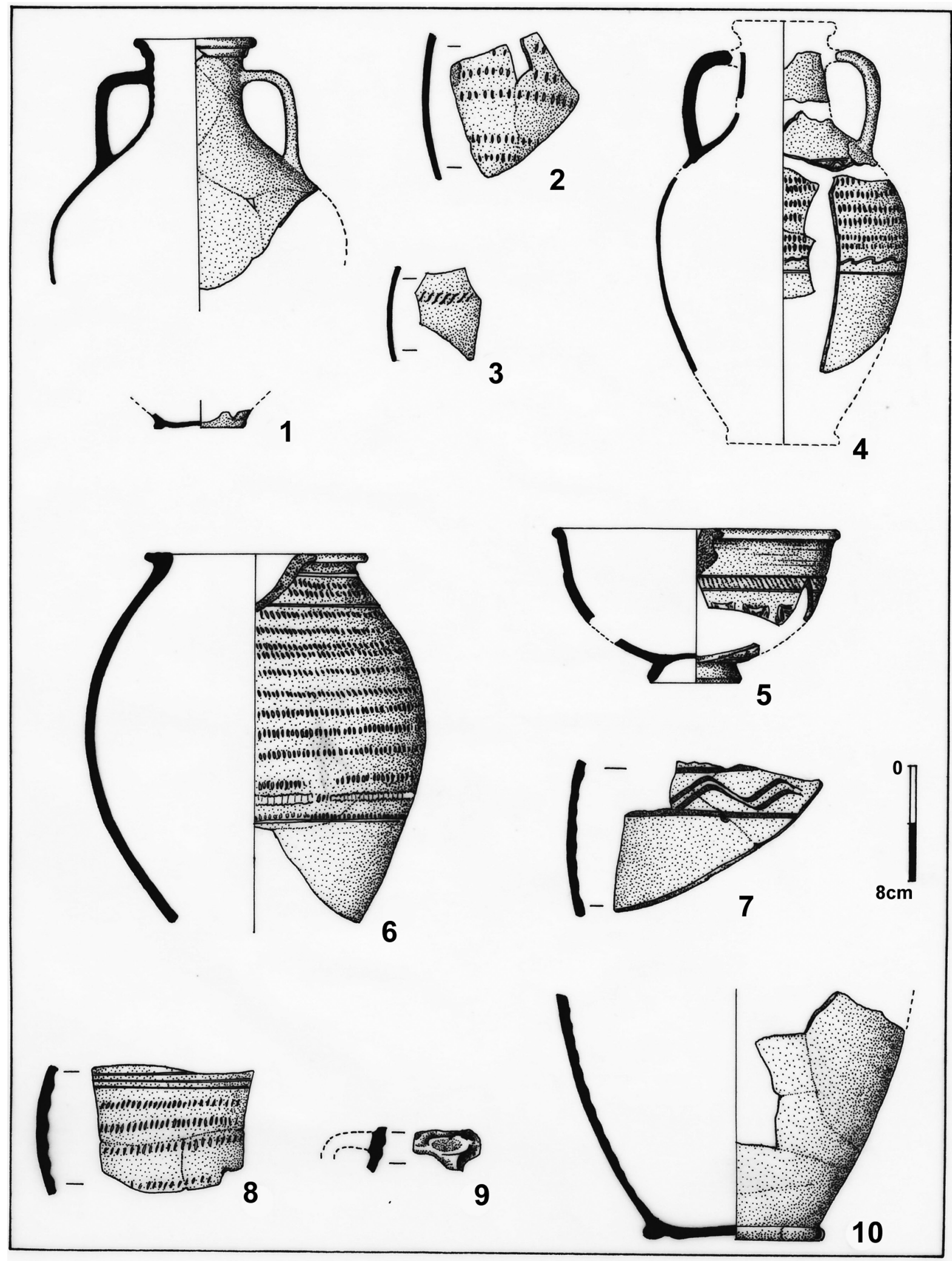

II. tábla. Alsóbogát-Csollányosi-erdő. M:1:4 


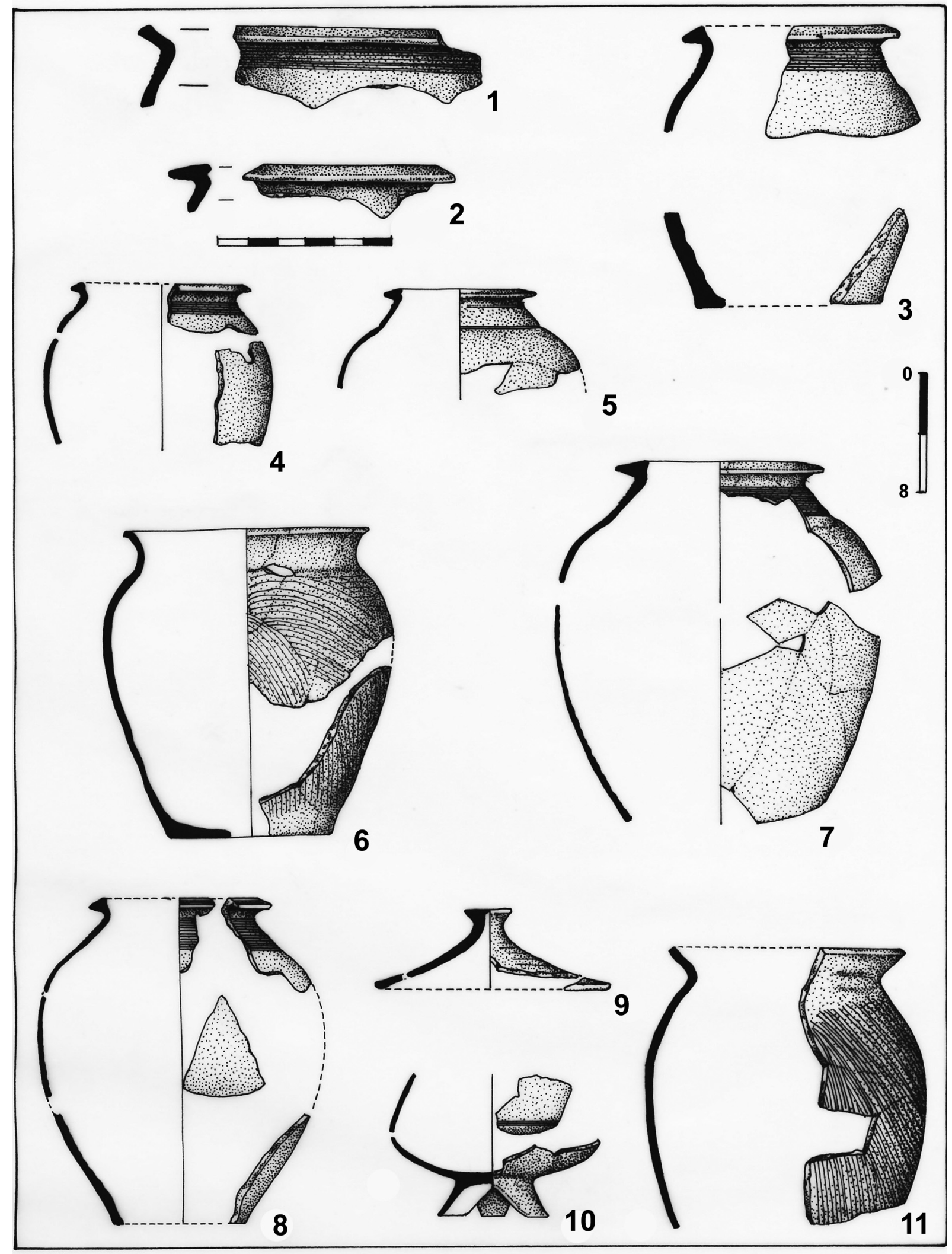

III. tábla. Alsóbogát-Csollányosi-erdő. 1. 3-11. M:1:4, 2. M:1:2 

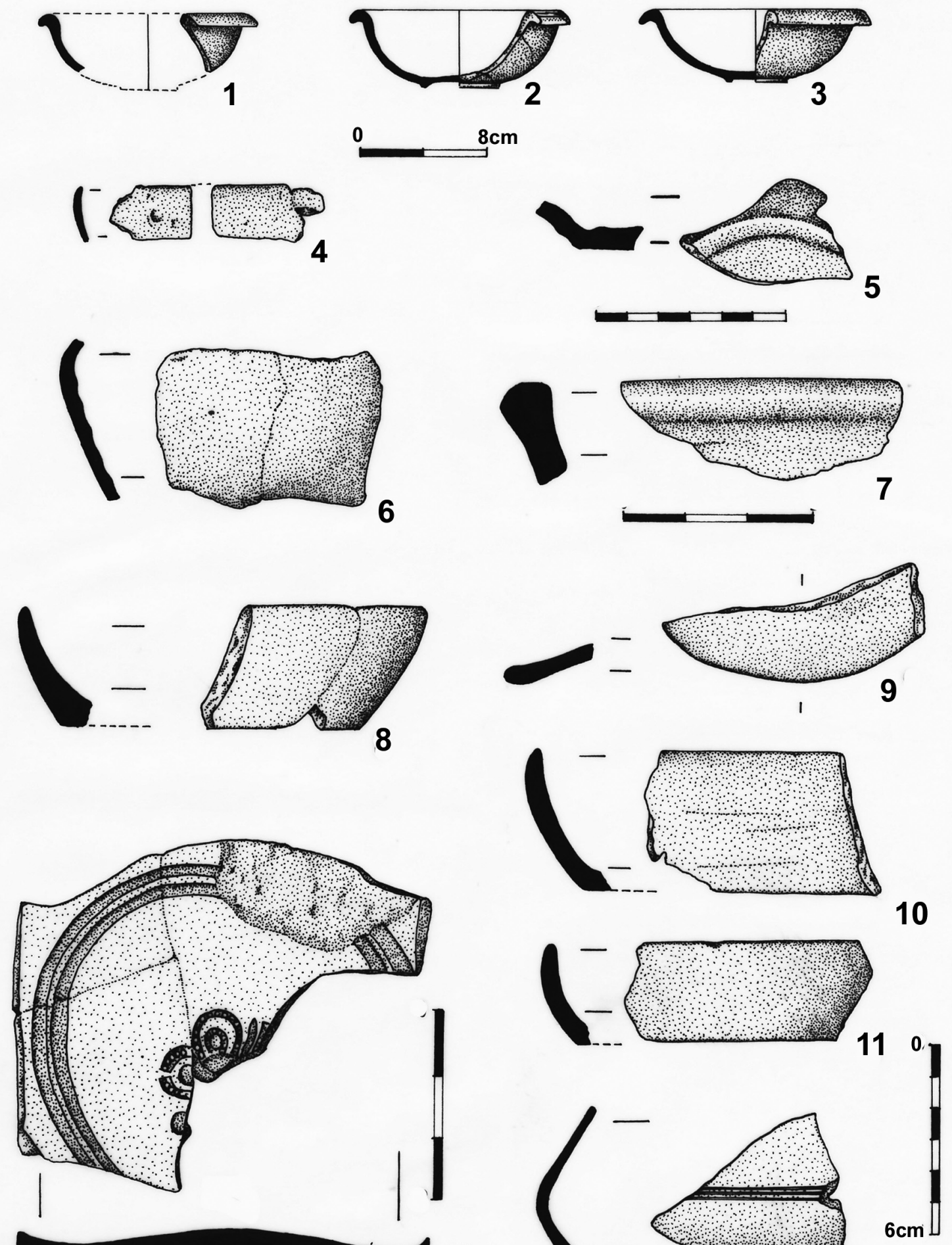


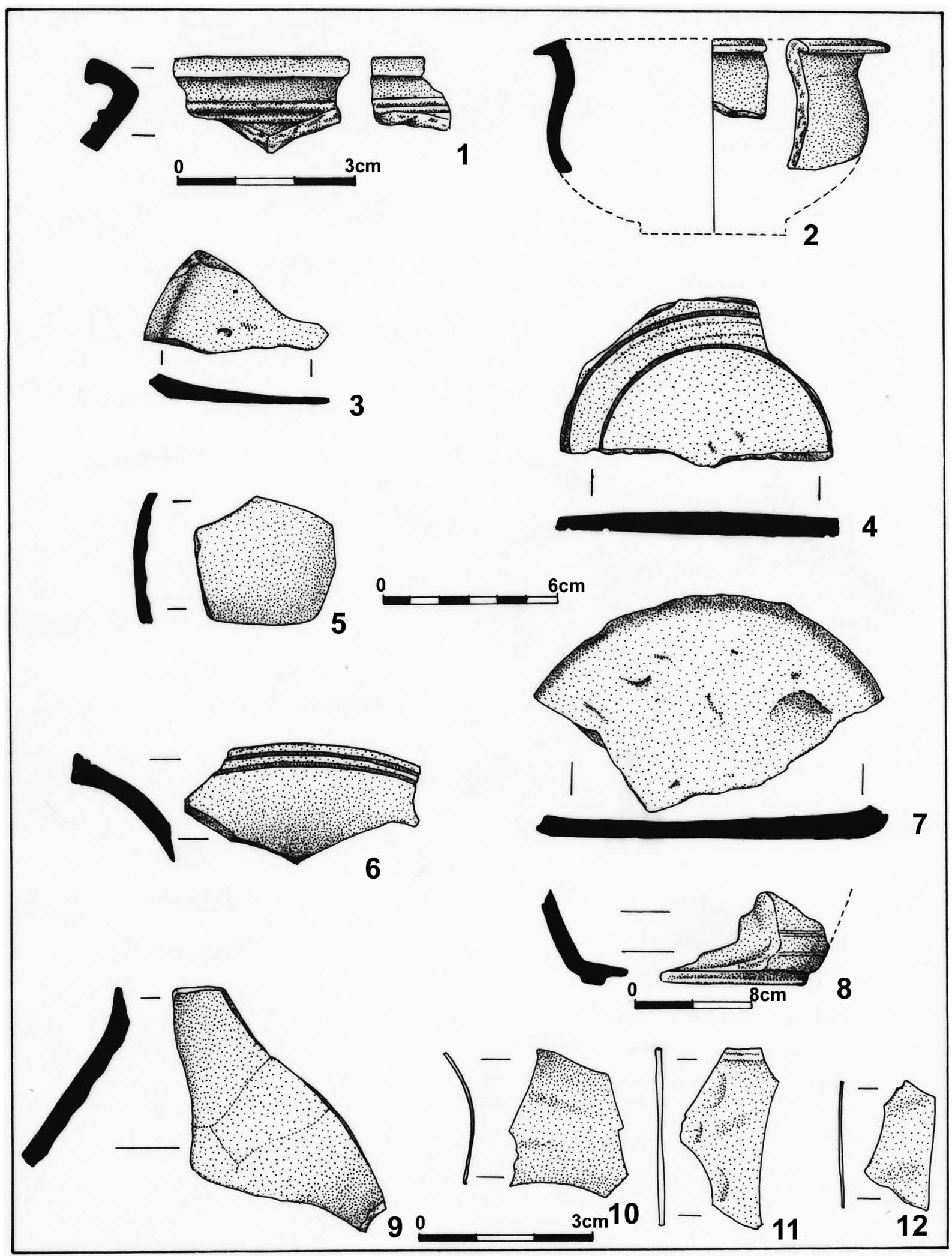

V. tábla. Alsóbogát-Csollányosi-erdő. 1. 6. 9-12. M:1:1, 2. 4-5. 7. M:1:2, 8. M:1:4 


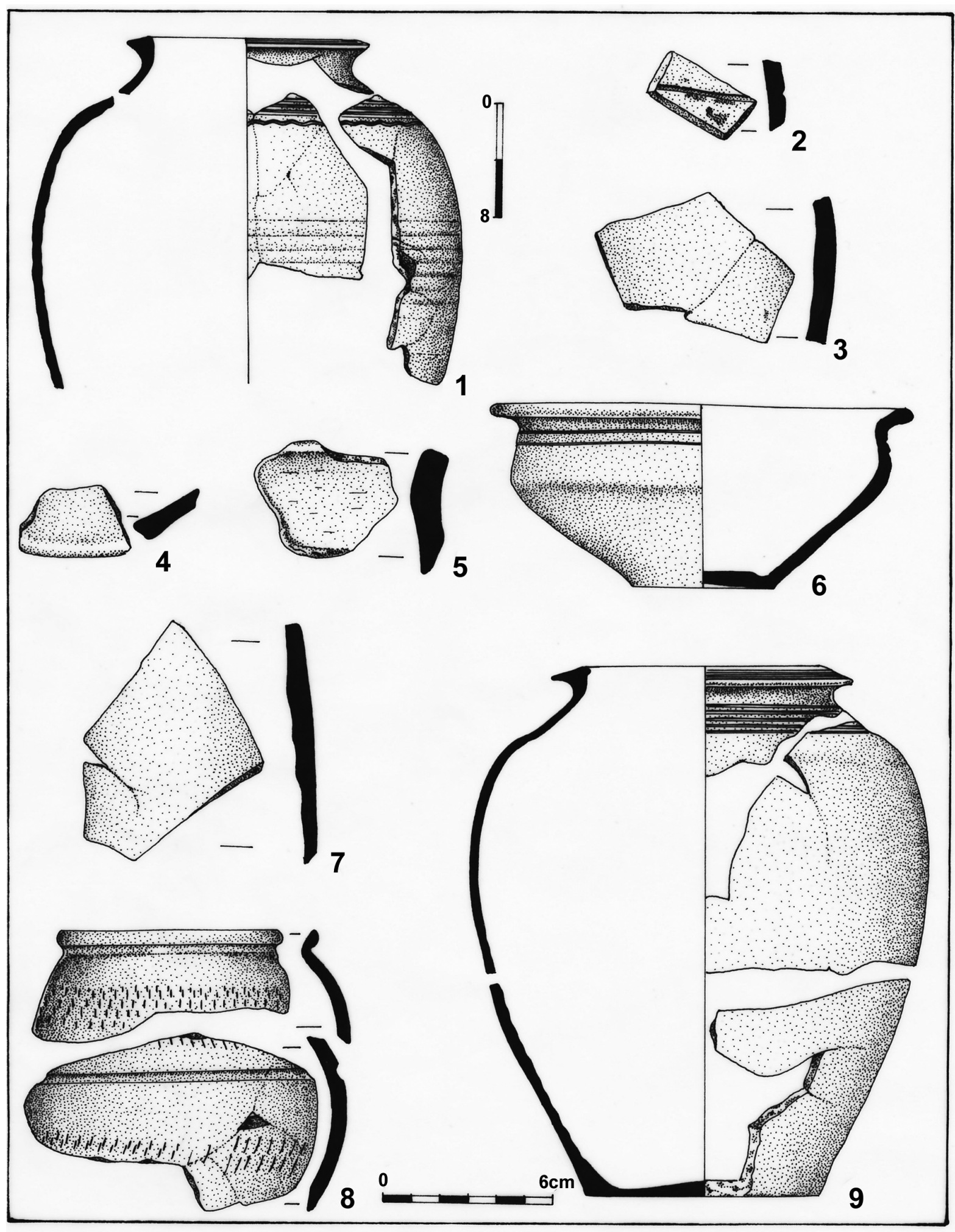

VI. tábla. Somogyaszaló-Deseda-erdő 1. halom. 1. M:1:4, 2-9. M:1:2 


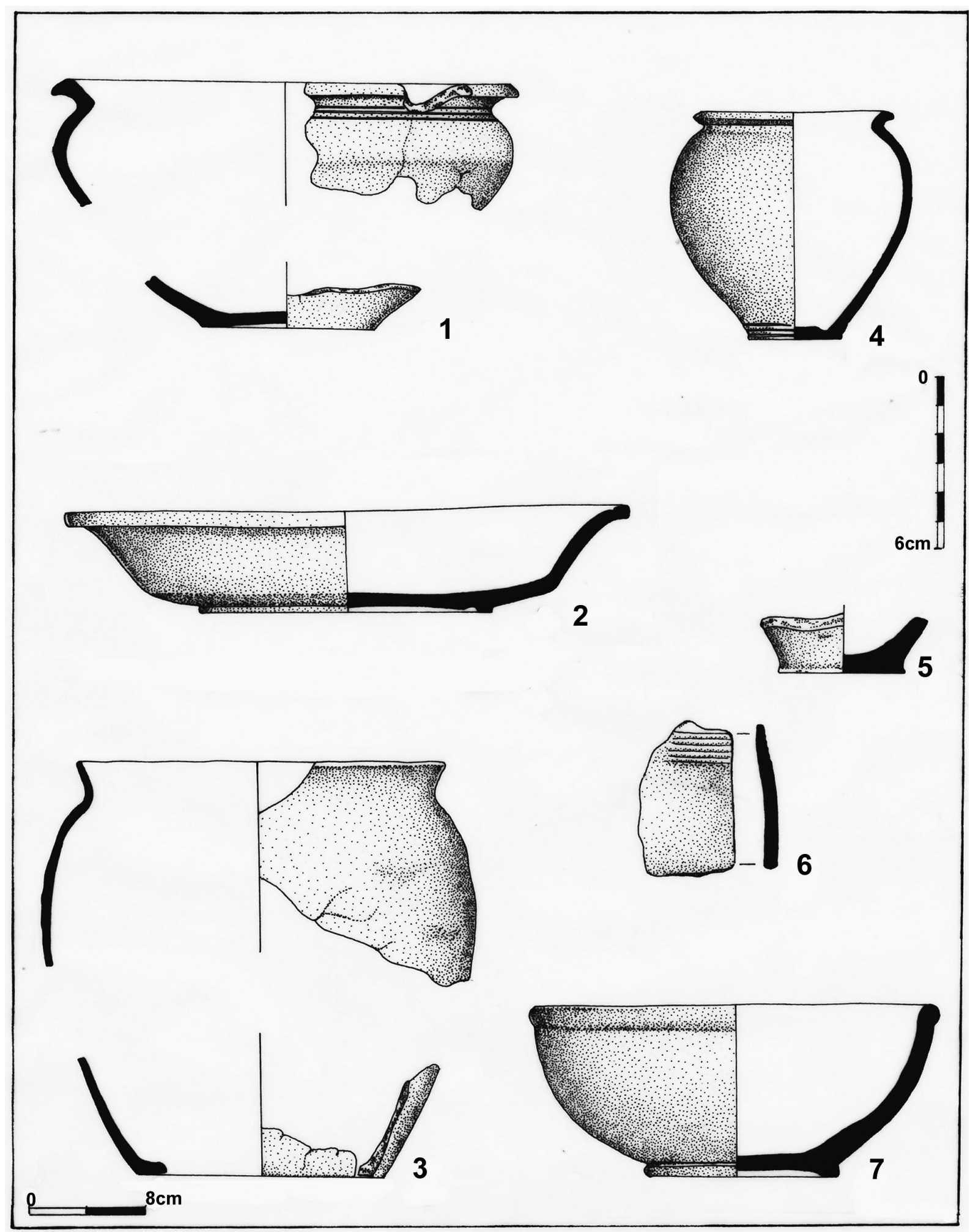

VII. tábla. Somogyaszaló-Deseda-erdő 2. halom. 1-2., 4-7. M:1:2, 3. M:1:4 


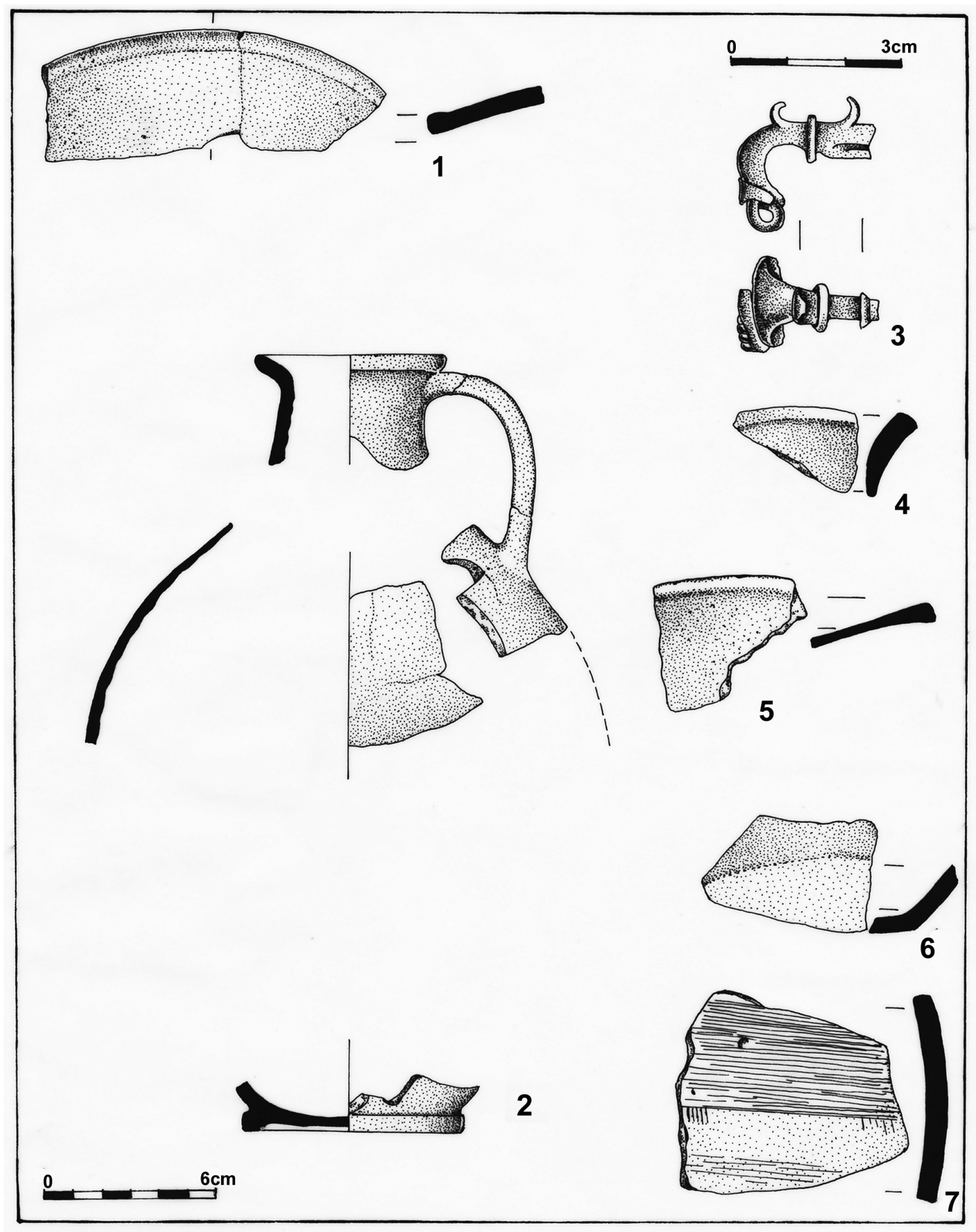

VIII. tábla. Somogyaszaló-Deseda-erdő 2. halom. 1-2.,4-7. M:1:2, 3. M:1:1 


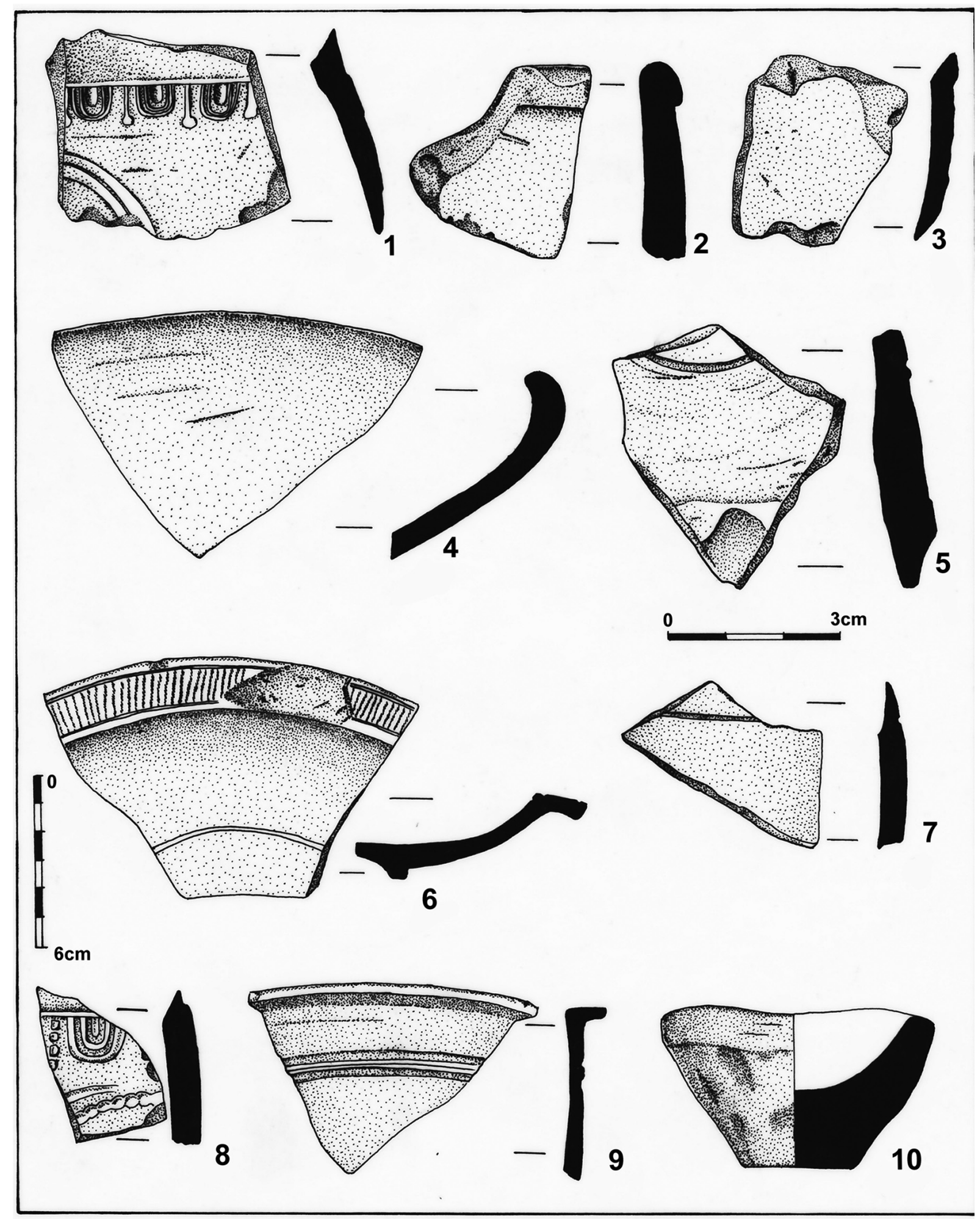

IX. tábla. Kaposvár-Kaposfüred-Desedapart. 1-5. , 7-10. M:1:1, 6. M: 1:2 


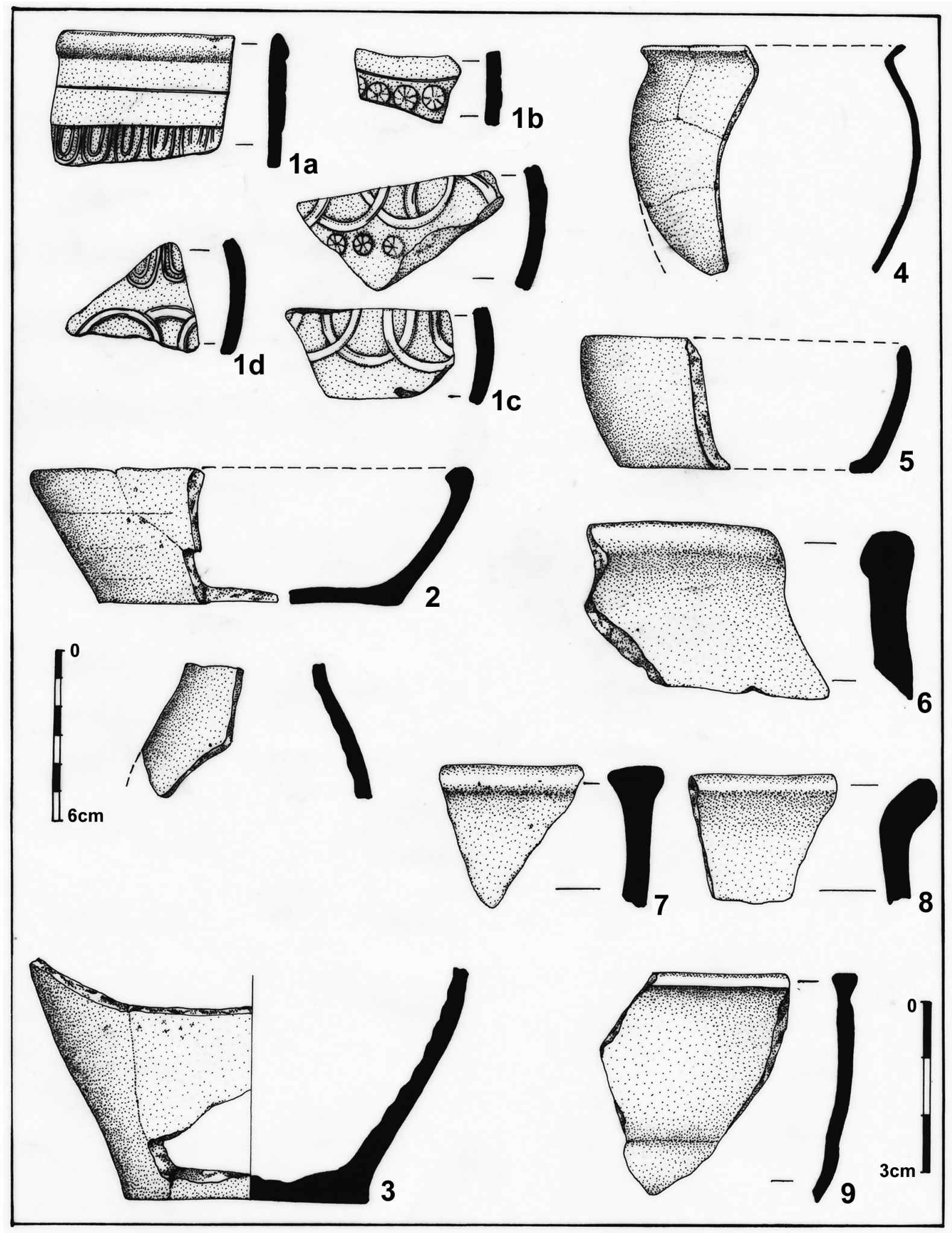

X. tábla. Somogyjád-Apánkai erdö1-4. 1. halom, 5-9. 2. halom. 1., 6-9. M:1:1, 2-5. M:1:2 


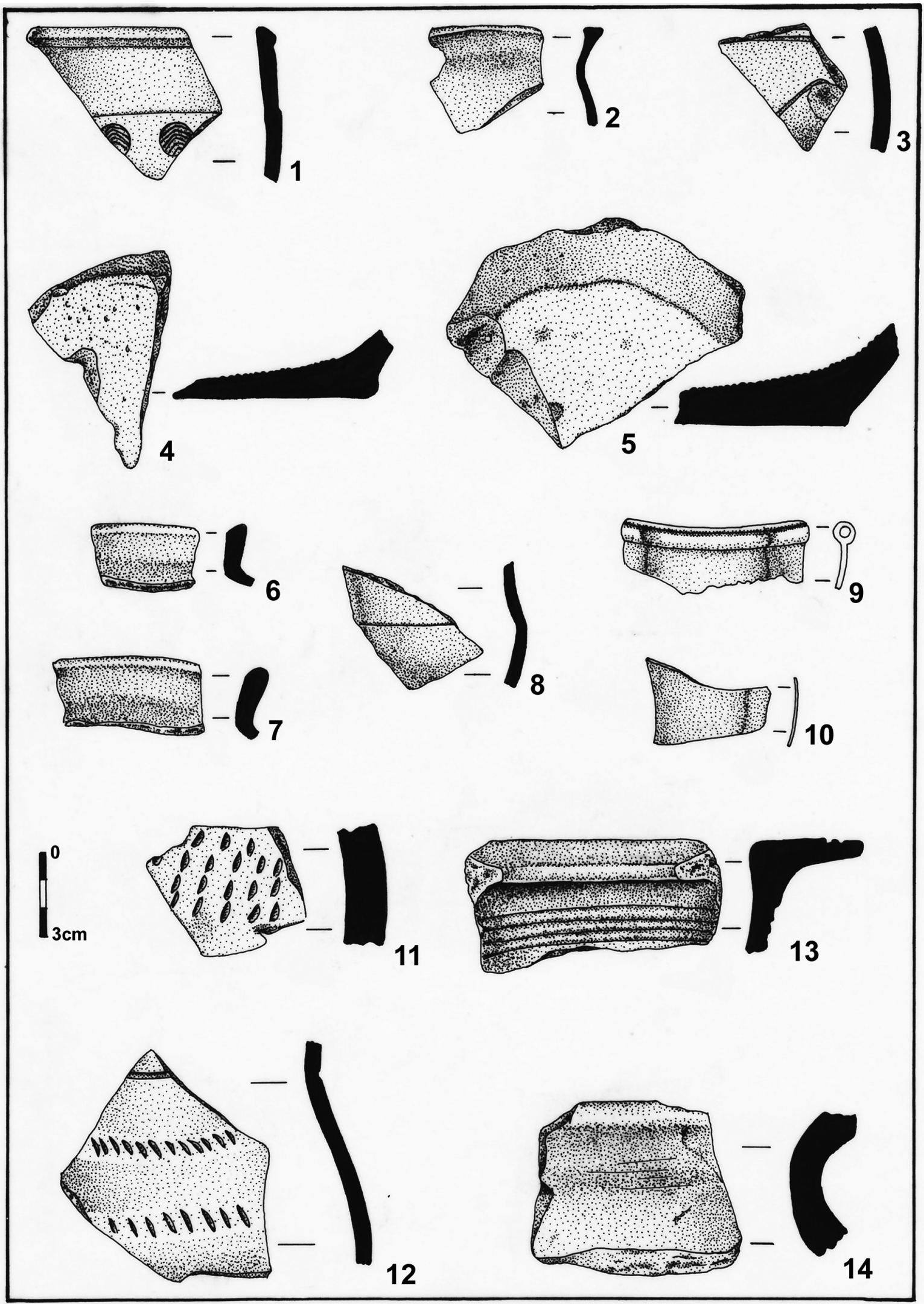

XI. tábla. 1-5. Gölle és Somogyszil határa. 6-10. Nagyberki 11-14. Öreglak1-5. M: 1:2, 6-14. M: 1:1 


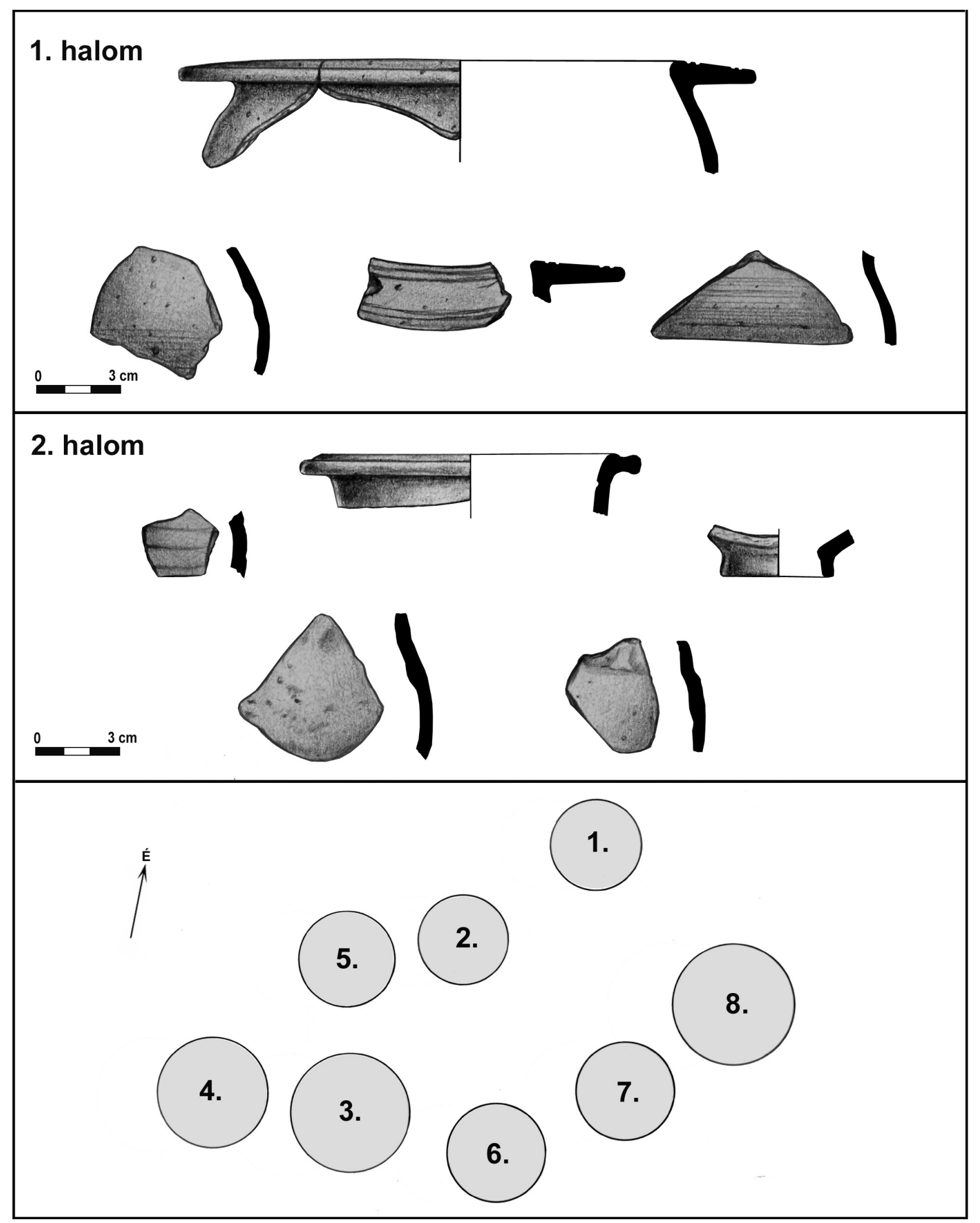




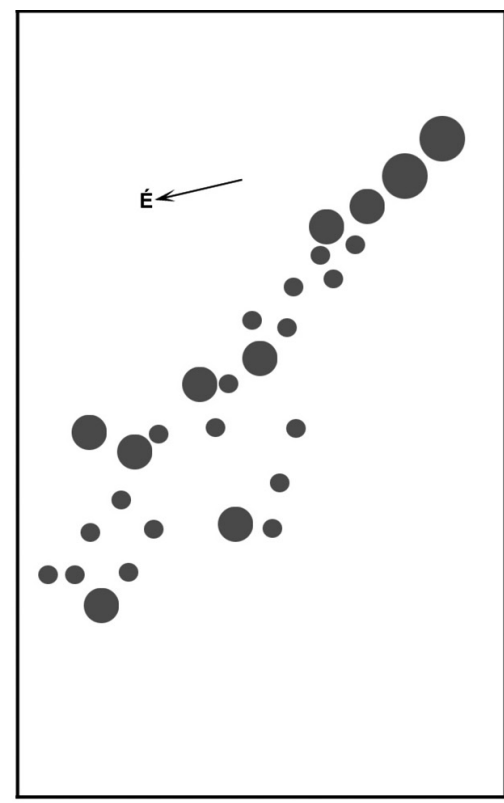

1.

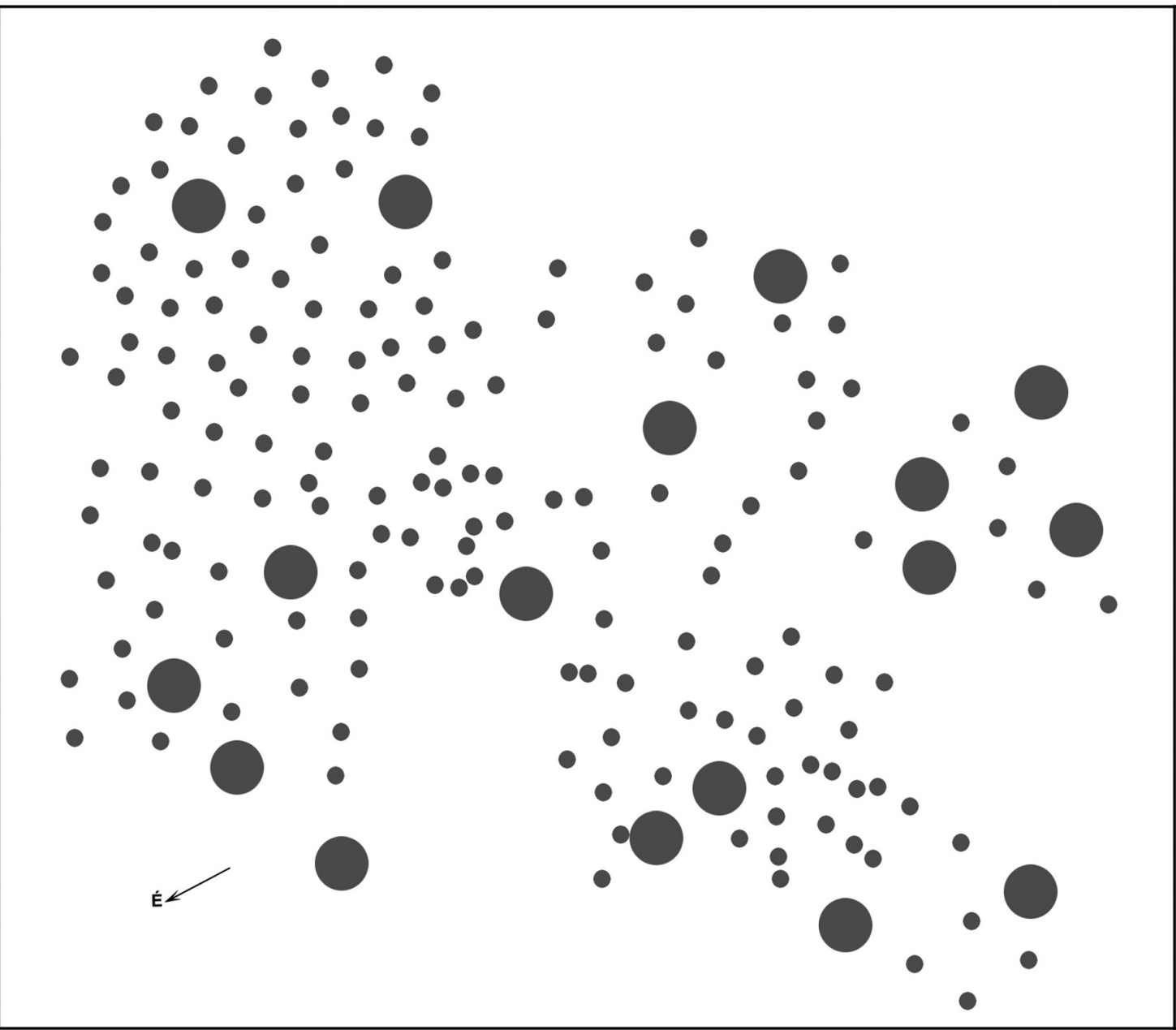

XIII. tábla. Temetőtérképek 1. Alsóbogát 2. Juta 3. Mosdós 4. Somogyjád 


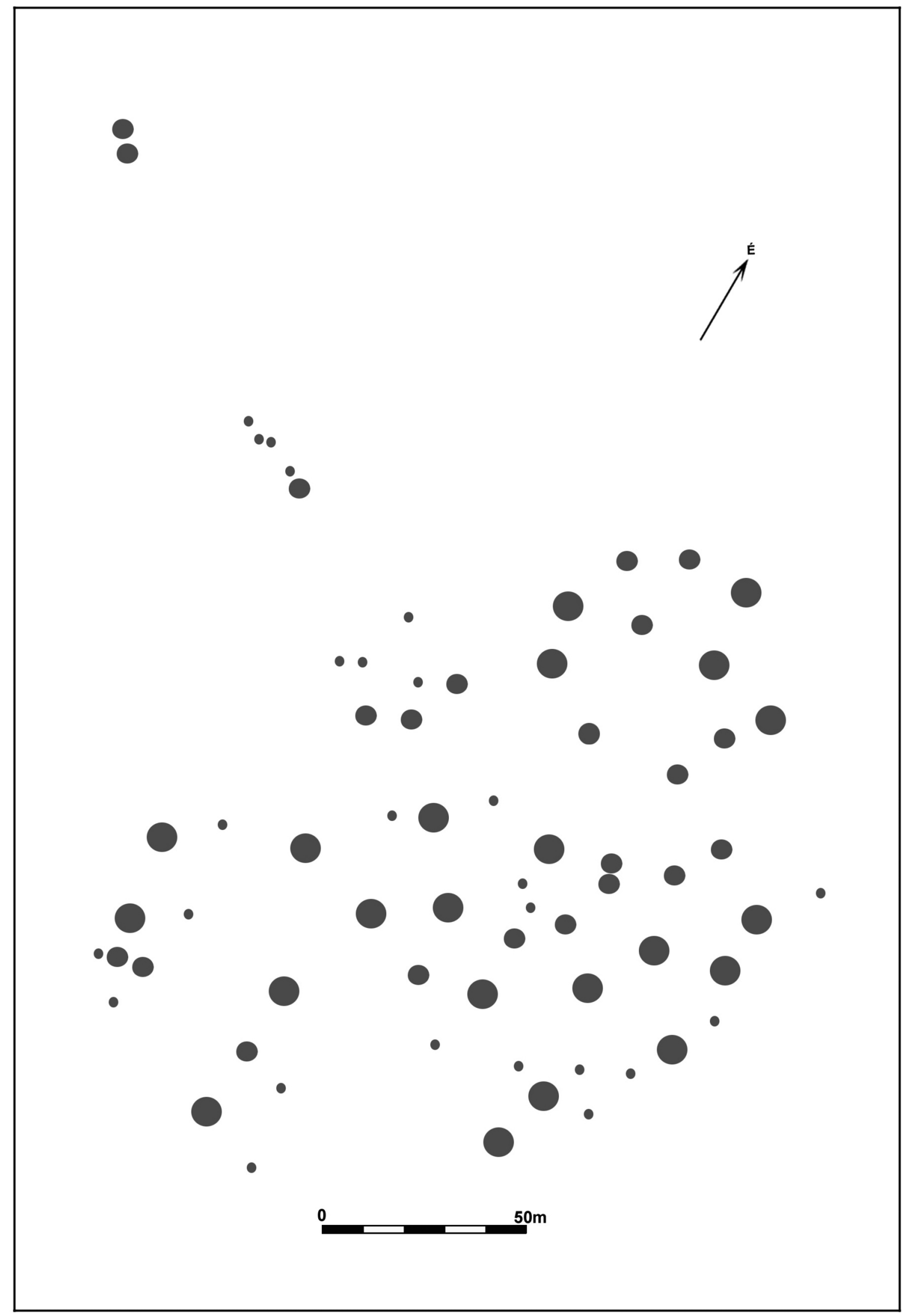




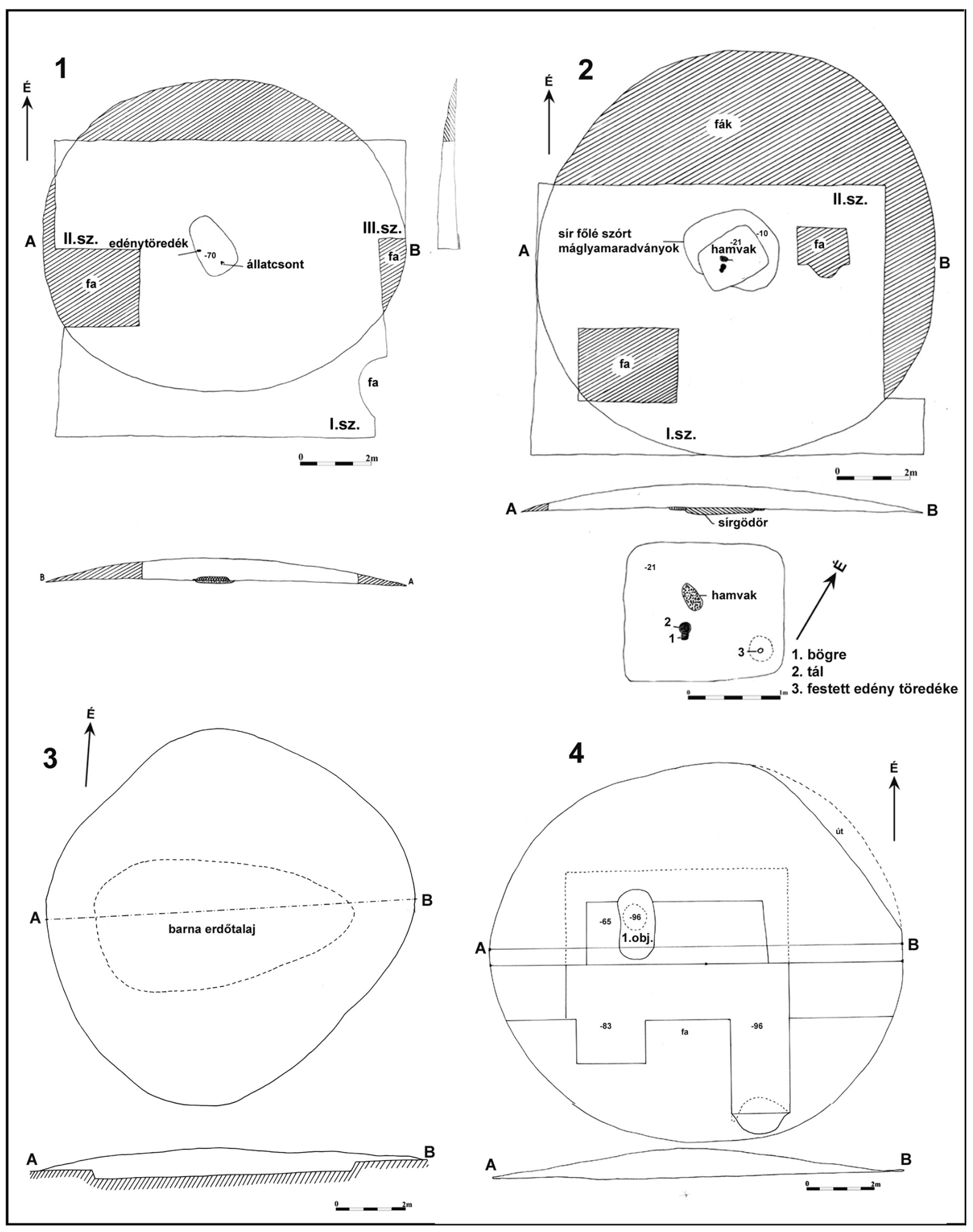

XV. tábla. 1-2. Somogyaszaló 1. és 2. halom 3. Somogyjád 2. halom 4. Somogyjád 1. halom 


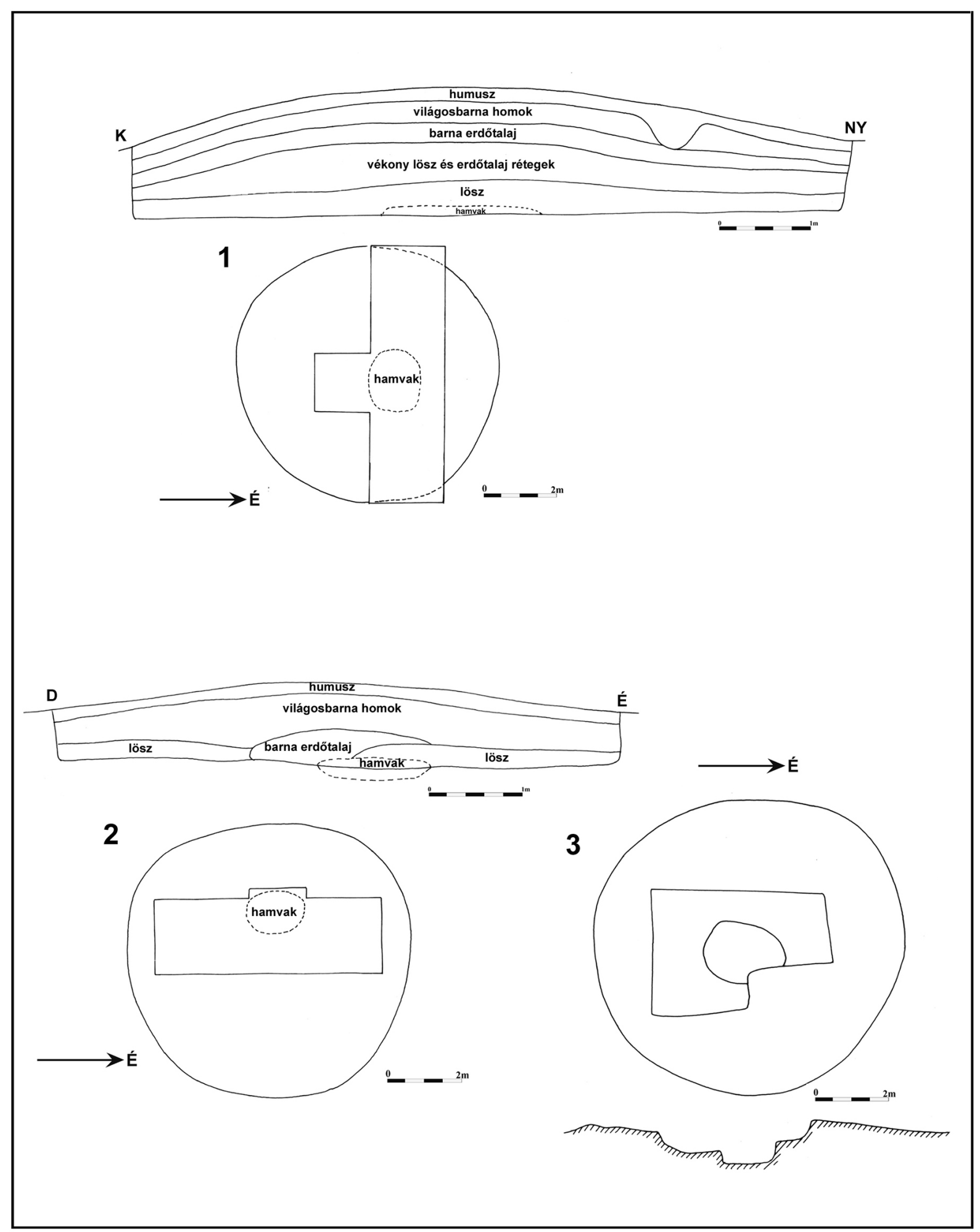




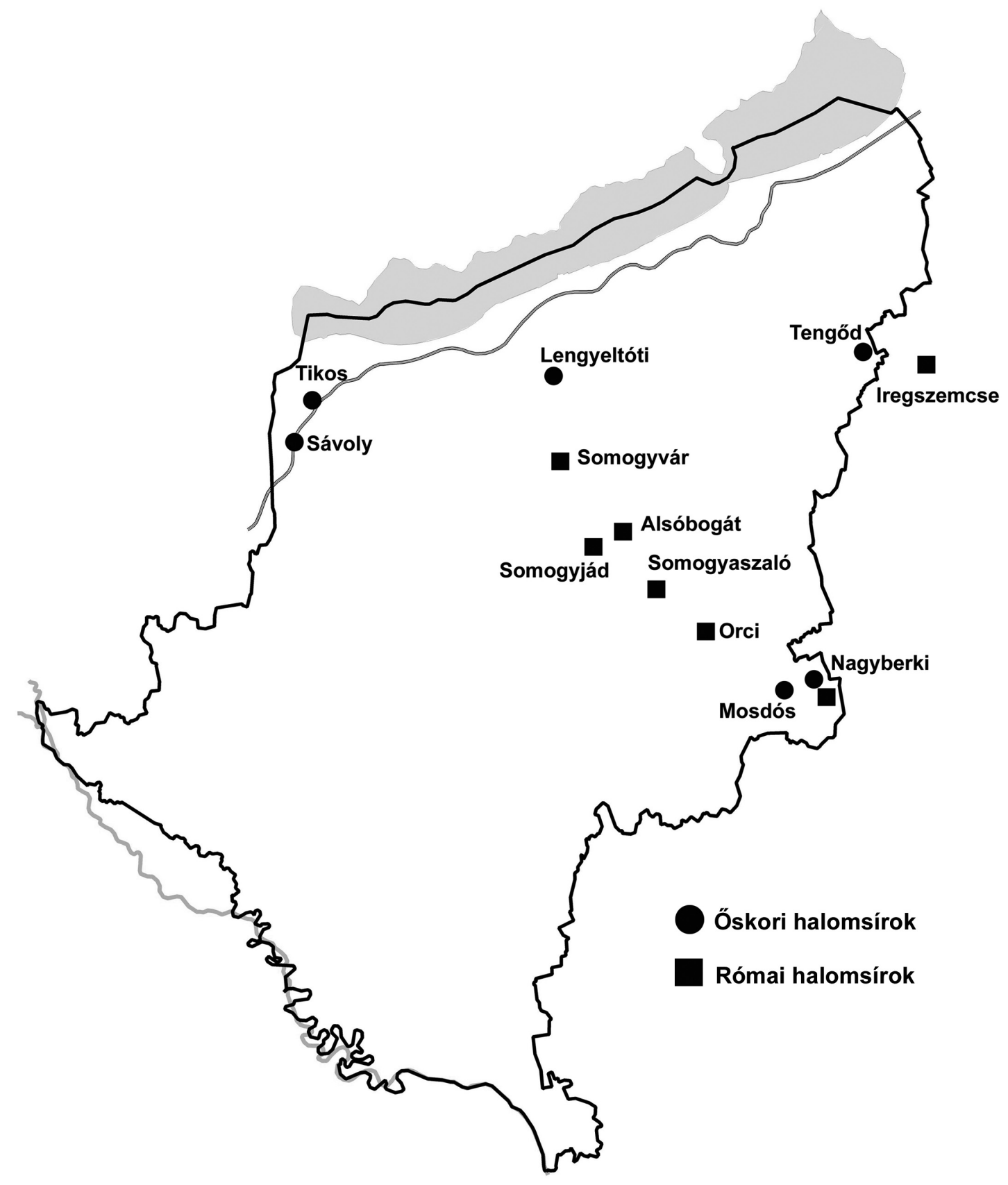

XVII. tábla. Őskori és római kori halomsírok térképe 


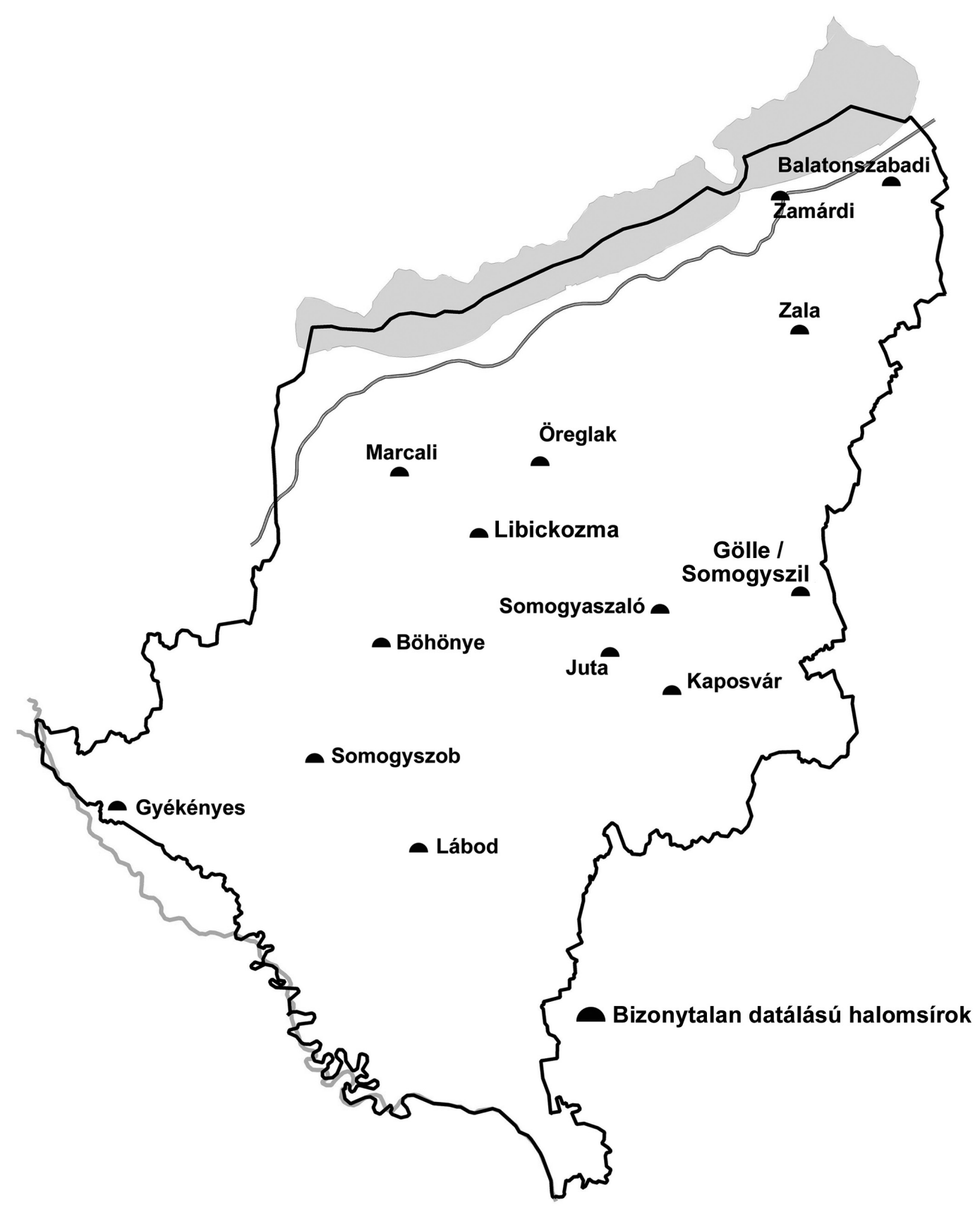


1.

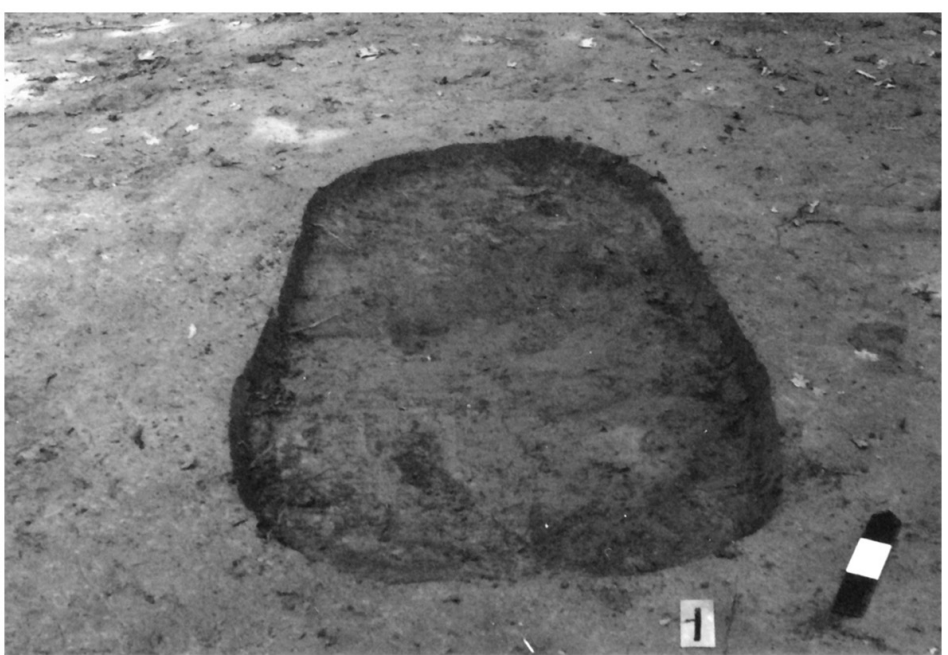

2.

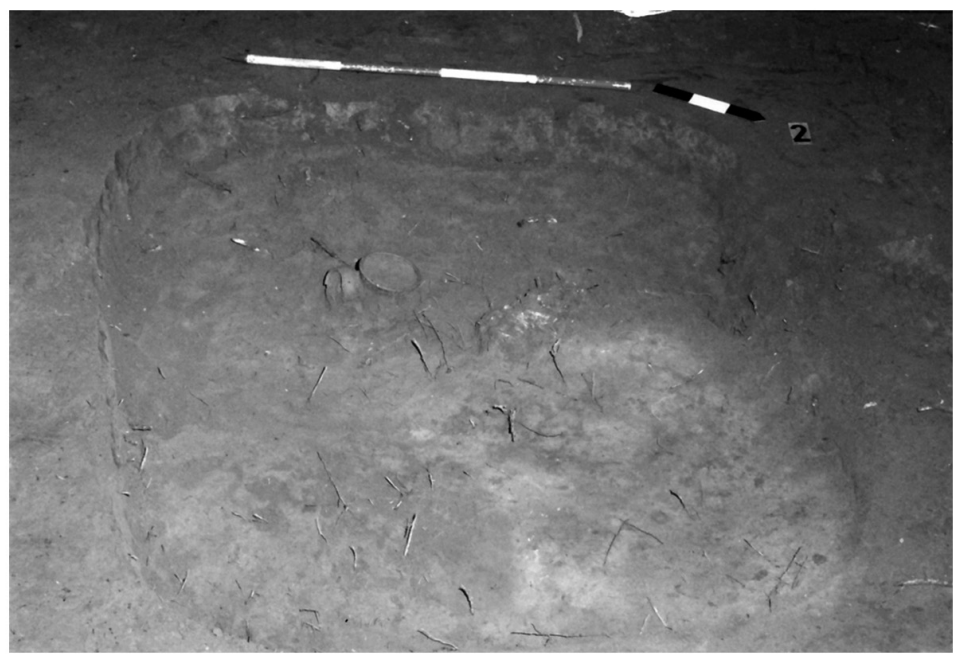

3.

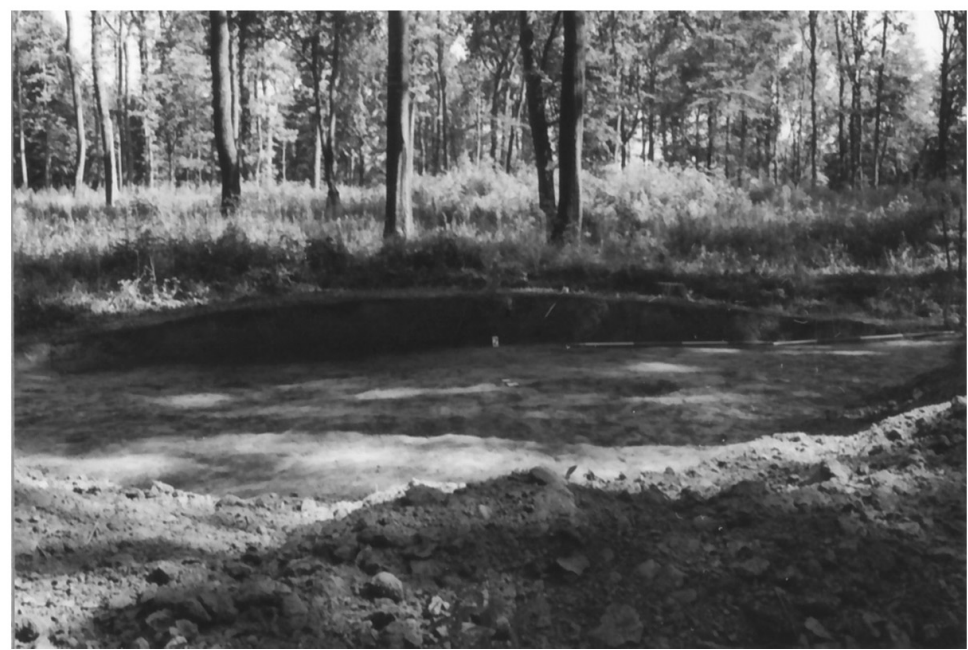

XIX. tábla. 1-2. Somogyaszaló-Deseda-erdö 1. és 2. halom sírgödre 3. Somogyjád-Apánkai erdö 2. halom metszete 
1.

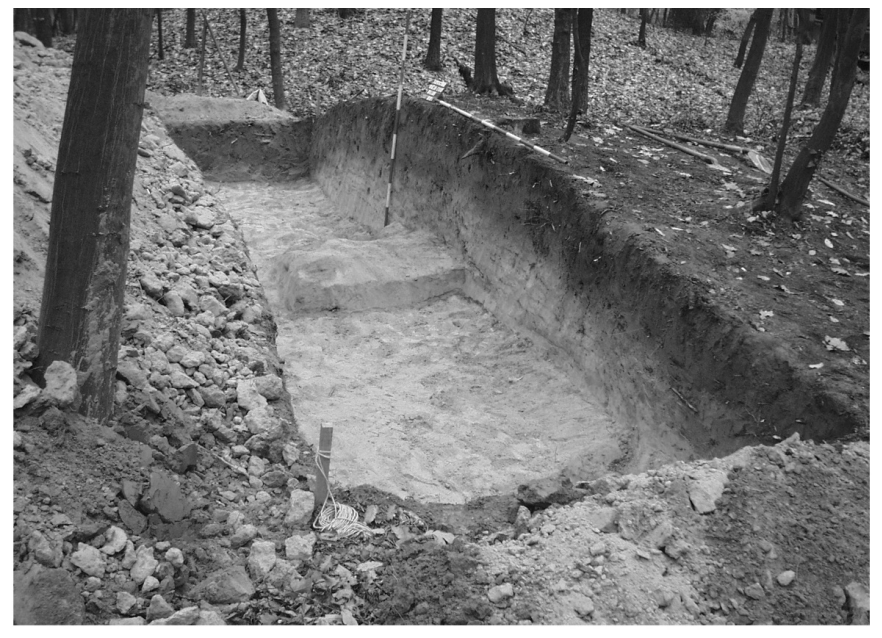

2.

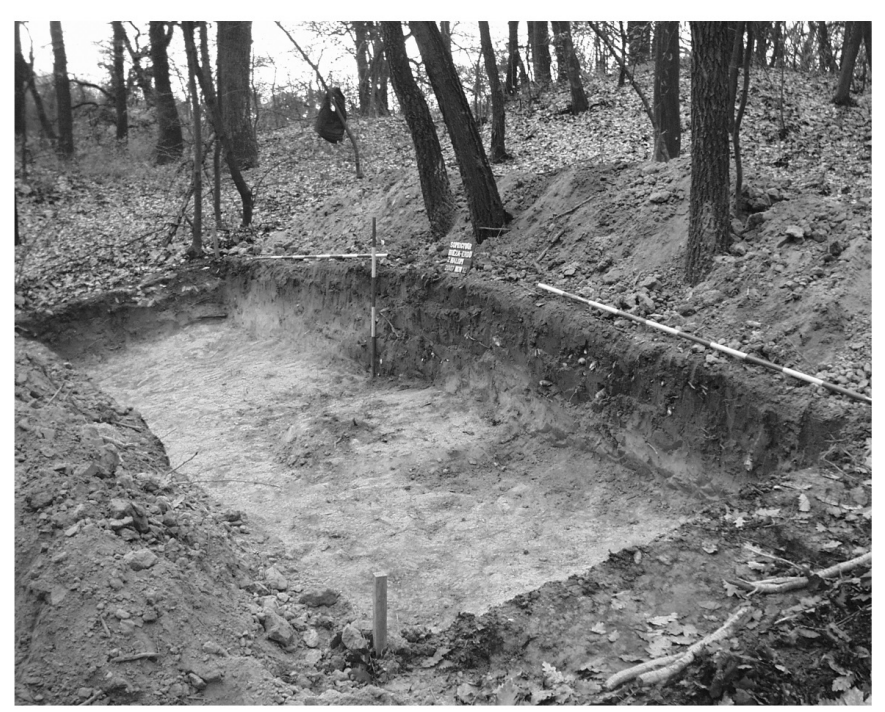

3.

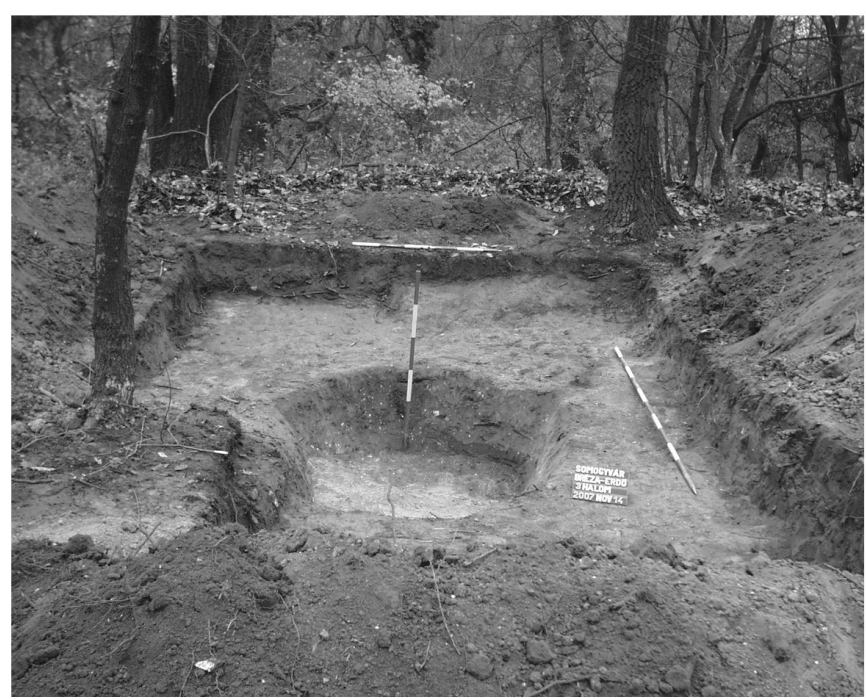

XX. tábla. Somogyvár - Bréza -erdő 1-3. halom 
1. táblázat. Alsóbogát - Csollányosi- erdő és Somogyaszaló - Deseda- erdő

\begin{tabular}{|c|c|c|c|}
\hline szám & magasság $(\mathrm{cm})$ & átmérő $(\mathrm{cm})$ & szint $(m)$ \\
\hline 1 & 70 & 1300 & 184.86 \\
\hline 2 & 40 & 824 & 184.72 \\
\hline 3 & 80 & 1262 & 184.71 \\
\hline 4 & 70 & 1258 & 184.80 \\
\hline 5 & 90 & 840 & 184.80 \\
\hline 6 & 90 & 864 & 184.88 \\
\hline 7 & 60 & 804 & 184.83 \\
\hline 8 & 60 & 844 & 184.87 \\
\hline 9 & 40 & 1298 & 184.84 \\
\hline 10 & 50 & 734 & 184.87 \\
\hline 11 & 90 & 1112 & 184.92 \\
\hline 12 & 130 & 1726 & 184.98 \\
\hline 13 & 190 & 1274 & 185.06 \\
\hline 14 & 45 & 925 & 184,49 \\
\hline 15 & 70 & 1070 & 183,88 \\
\hline 16 & 55 & 1010 & 183,43 \\
\hline 17 & $?$ & $?$ & 183,2 \\
\hline 18 & 60 & 970 & 184,13 \\
\hline 19 & 85 & 910 & 183,76 \\
\hline 20 & 40 & 805 & 183,45 \\
\hline 21 & 40 & 908 & 182,68 \\
\hline 22 & 45 & 885 & 182,52 \\
\hline 23 & 90 & 1175 & 182,02 \\
\hline 24 & 55 & 905 & 181,62 \\
\hline 25 & 50 & 810 & 181,15 \\
\hline 26 & 40 & 800 & 183,76 \\
\hline 27 & 50 & 900 & 185,12 \\
\hline
\end{tabular}

2. táblázat. Somogyaszaló - Deseda- erdő

\begin{tabular}{|c|c|c|c|}
\hline szám & magasság $(\mathbf{c m})$ & átmérö $\mathbf{( c m})$ & szint $\mathbf{( m )}$ \\
\hline 1. & & & 159,85 \\
\hline 2. & 230 & 916 & 159,85 \\
\hline 3. & 50 & $?$ & 157,4 \\
\hline 4. & 40 & 380 & 157,6 \\
\hline 5. & 20 & 454 & 157,2 \\
\hline 6. & 100 & $340 ?$ & 157,7 \\
\hline 7. & 40 & 1114 & 157,5 \\
\hline 8. & 90 & 644 & 157,72 \\
\hline 9. & & & $?$ \\
\hline 10. & 50 & 372 & 157,32 \\
\hline 11. & 60 & 848 & 157,42 \\
\hline 12. & $?$ & $?$ & 156,82 \\
\hline 13. & 60 & 1194 & 157,33 \\
\hline 14. & $?$ & 544 & 156,73 \\
\hline 15. & $?$ & $?$ & 157,23 \\
\hline 16. & 150 & 1516 & 158,23 \\
\hline 17. & 46 & 1748 & 156,38 \\
\hline 18. & 106 & 990 & 156,38 \\
\hline
\end{tabular}




\begin{tabular}{|c|c|c|c|}
\hline 19. & 60 & 880 & 156,92 \\
\hline 20. & 60 & 970 & 156,72 \\
\hline 21. & & & $?$ \\
\hline 22. & 80 & 1234 & 156,4 \\
\hline 23. & 60 & 856 & 156,6 \\
\hline 24. & $?$ & $?$ & 156,1 \\
\hline 25. & 80 & átl. 1552 & 156 \\
\hline 26. & 10 & 790 & 155,1 \\
\hline 27. & 45 & átl. 732 & 152,78 \\
\hline 28. & 40 & átl. 1387 & 154,88 \\
\hline 29. & 140 & 2648 & 155,68 \\
\hline 30. & 130 & 1482 & 156,55 \\
\hline 31. & 80 & 1044 & 156,45 \\
\hline 32. & 10 & 998 & 155,25 \\
\hline 33. & 30 & 914 & 154,45 \\
\hline 34. & 60 & 918 & 155,05 \\
\hline 35. & 60 & 1384 & 153,07 \\
\hline 36. & 282 & 1494 & 153,37 \\
\hline 37. & 60 & 1384 & 150,05 \\
\hline 38. & $?$ & ? korr.: 1458 & 149,15 \\
\hline 39. & 100 & 1338 & 151,15 \\
\hline 40. & 40 & $?$ & 150,75 \\
\hline 41. & 60 & 1120 (korr.: 1073,64) & 155,39 \\
\hline 42. & 140 & 1426 & 155,6 \\
\hline 43. & 70 & 536 & 153,95 \\
\hline 44. & 70 & 846 & 153,95 \\
\hline 45. & 50 & 1000 & 152,5 \\
\hline 46. & 70 & 634 & 154,65 \\
\hline 47. & 40 & 764 & 155,94 \\
\hline 48. & 40 & 1050 & 156,14 \\
\hline 49. & 45 & $?$ & 155,89 \\
\hline 50. & 40 & 1248 & 156,24 \\
\hline 51. & 70 & 616 & 155,34 \\
\hline 52. & 70 & 1200 & 155,79 \\
\hline 53. & 70 & 714 & 155,89 \\
\hline 54. & 40 & 1054 & 155,99 \\
\hline 55. & 90 & 1384 & 155,77 \\
\hline 56. & 60 & $?$ & 155,67 \\
\hline 57. & 40 & 1200 & 156,07 \\
\hline 58. & 114 & $?$ & 155,67 \\
\hline 59. & 50 & 1254 & 155,25 \\
\hline 60. & 30 & 820 & 155,15 \\
\hline 61. & 70 & 1020 & 155,23 \\
\hline 62. & 40 & 756 & 155,03 \\
\hline 63. & 50 & 840 & 154,68 \\
\hline 64. & 40 & 1016 & 154,58 \\
\hline 65. & 40 & 820 & 154,29 \\
\hline 66. & 10 & 674 & $153,49 ?$ \\
\hline 67. & 70 & 930 & 154,19 \\
\hline 68. & 20 & 696 & 153,69 \\
\hline
\end{tabular}


3. táblázat. Somogyjád - Apánkai - erdő

\begin{tabular}{|c|c|c|c|}
\hline szám & magasság $(\mathrm{cm})$ & átmérő (cm) & szint (m) \\
\hline 1. & 60 & 955 & 162,92 \\
\hline 2. & 30 & 895 & 162,22 \\
\hline 3. & 85 & 1140 & 162,41 \\
\hline 4. & 80 & 1042 & 161,92 \\
\hline 5. & 75 & 1034 & 161,5 \\
\hline 6. & 60 & 966 & 161,92 \\
\hline 7. & 80 & 1157 & 162,92 \\
\hline 8. & 60 & 1011 & 162,54 \\
\hline 9. & 40 & 1126 & 162,57 \\
\hline 10. & 60 & 1028 & 162,57 \\
\hline 11. & 90 & 1065 & 162,92 \\
\hline 12. & 75 & 1205 & 162,82 \\
\hline 13. & 50 & 855 & 162,67 \\
\hline 14. & 55 & 840 & 162,62 \\
\hline 15. & 70 & 1140 & 162,67 \\
\hline 16. & 50 & 678 & 162,44 \\
\hline 17. & 60 & 942 & 162,44 \\
\hline 18. & 40 & 868 & 162,42 \\
\hline 19. & 50 & 831 & 162,5 \\
\hline 20. & 80 & 976 & 162,52 \\
\hline 21. & 110 & 1221 & 161,22 \\
\hline 22. & 85 & 1045 & 160,42 \\
\hline 23. & 55 & 866 & 161,06 \\
\hline 24. & 30 & 690 & 161,87 \\
\hline 25. & 50 & 888 & 162,47 \\
\hline 26. & 65 & 1036 & 162,26 \\
\hline 27. & 75 & 888 & 162,25 \\
\hline 28. & 55 & 977 & 162,6 \\
\hline 29. & 80 & 1067 & 162,37 \\
\hline 30. & 70 & 978 & 161,67 \\
\hline 31. & 120 & 1263 & 162,81 \\
\hline 32. & 35 & 754 & 162,43 \\
\hline 33. & 60 & 1086 & 162,63 \\
\hline 34. & 20 & 683 & 162,46 \\
\hline 35. & 30 & 586 & 162,48 \\
\hline 36. & 35 & 923 & 162,29 \\
\hline 37. & 30 & 727 & 161,81 \\
\hline 38. & 30 & 639 & 161,41 \\
\hline 39. & 50 & 786 & 161,03 \\
\hline 40. & 39 & 940 & 162,35 \\
\hline 41. & 19 & 820 & 161,71 \\
\hline 42. & 40 & 970 & 160,01 \\
\hline 43. & 56 & 1180 & 159,53 \\
\hline 44. & 60 & 940 & 159,53 \\
\hline 45. & 55 & 1040 & 158,96 \\
\hline
\end{tabular}




\begin{tabular}{|c|c|c|c|}
\hline szám & magasság $(\mathrm{cm})$ & átmérő $(\mathrm{cm})$ & szint (m) \\
\hline 46. & 55 & 1090 & 159,89 \\
\hline 47. & 36 & 970 & 159,31 \\
\hline 48. & 18 & 480 & 158,8 \\
\hline 49. & 50 & 1060 & 158,86 \\
\hline 50. & 75 & 1330 & 158,46 \\
\hline 51. & 34 & 830 & 159,23 \\
\hline 52. & 44 & 820 & 159,01 \\
\hline 53. & 80 & 1010 & 158,93 \\
\hline 54. & 90 & 1210 & 159,4 \\
\hline 55. & 56 & 900 & 158,81 \\
\hline 56. & 90 & 1140 & 158,55 \\
\hline 57. & 42 & 780 & 158,11 \\
\hline 58. & 30 & 690 & 157,99 \\
\hline 59. & 35 & 920 & 157,86 \\
\hline 60. & 24 & 920 & 158,04 \\
\hline 61. & 22 & 790 & 158,26 \\
\hline 62. & 50 & 1000 & 158,88 \\
\hline 63. & 48 & 870 & 159,04 \\
\hline 64. & 30 & 680 & 158,75 \\
\hline 65. & 20 & 610 & 158,88 \\
\hline 66. & 61 & 1020 & 159,41 \\
\hline 67. & 38 & 910 & 159,58 \\
\hline 68. & 40 & 870 & 159,76 \\
\hline 69. & 24 & 800 & 159,58 \\
\hline 70. & 74 & 1090 & 159,76 \\
\hline 71. & 76 & 1010 & 160,36 \\
\hline 72. & 40 & 890 & 160,46 \\
\hline 73. & 56 & 900 & 159,91 \\
\hline 74. & 62 & 1040 & 160,18 \\
\hline 75. & 20 & 720 & 160,41 \\
\hline 76. & 22 & 700 & 159,464 \\
\hline 77. & 40 & 810 & 159,93 \\
\hline 78. & 30 & 800 & 160,29 \\
\hline 79. & 25 & 740 & 160,27 \\
\hline 80. & 10 & 710 & 160,71 \\
\hline 81. & 14 & 600 & 160,57 \\
\hline 82. & 20 & 680 & 160,89 \\
\hline 83. & 40 & 660 & 161,03 \\
\hline 84. & 30 & 614 & 159,18 \\
\hline 85. & 40 & 880 & 159,08 \\
\hline 86. & 25 & 790 & 159,53 \\
\hline 87. & 25 & 620 & 159,65 \\
\hline 88. & 10 & 480 & 159,4 \\
\hline 89. & 40 & 690 & 159,4 \\
\hline 90. & 40 & 697 & 159,78 \\
\hline 91. & 40 & 755 & 160,08 \\
\hline 92. & 40 & 765 & 160,01 \\
\hline
\end{tabular}




\begin{tabular}{|c|c|c|c|}
\hline szám & magasság $(\mathrm{cm})$ & átmérő $(\mathrm{cm})$ & szint (m) \\
\hline 93. & 30 & 700 & 160,23 \\
\hline 94. & 20 & 610 & 160,48 \\
\hline 95. & 50 & 850 & 159,89 \\
\hline 96. & 35 & 880 & 159,61 \\
\hline 97. & 20 & 700 & 159,88 \\
\hline 98. & 20 & 640 & 159,98 \\
\hline 99. & 80 & 1190 & 160,68 \\
\hline 100. & 10 & 460 & 159,53 \\
\hline 101. & 20 & 500 & 159,88 \\
\hline 102. & 20 & 640 & 159,48 \\
\hline 103. & 25 & 670 & 160,06 \\
\hline 104. & 10 & 530 & 160 \\
\hline 105. & 55 & 1090 & 160,48 \\
\hline 106. & 20 & 780 & 160,36 \\
\hline 107. & 20 & 660 & 160,4 \\
\hline 108. & 40 & 1000 & 159,48 \\
\hline 109. & 20 & 580 & 159,58 \\
\hline 110. & 25 & 640 & 160,59 \\
\hline 111. & 40 & 820 & 160,56 \\
\hline 112. & 25 & 680 & 160,6 \\
\hline 113. & 32 & 870 & 160,71 \\
\hline 114. & 65 & 950 & 161 \\
\hline 115. & 10 & 450 & 160,28 \\
\hline 116. & 50 & 830 & 160,93 \\
\hline 117. & 10 & 520 & 160,27 \\
\hline 118. & 70 & 1050 & 160,79 \\
\hline 119. & 20 & 700 & 160,58 \\
\hline 120. & 60 & 1050 & 160,79 \\
\hline 121. & 20 & 580 & 160 \\
\hline 122. & 20 & 620 & 160,09 \\
\hline 123. & 25 & 580 & 160,23 \\
\hline 124. & 40 & 810 & 160,4 \\
\hline 125. & 20 & 450 & 160,38 \\
\hline 126. & 20 & 470 & 160,73 \\
\hline 127. & 30 & 730 & 160,94 \\
\hline 128. & 15 & 630 & 160,62 \\
\hline 129. & 20 & 770 & 160,79 \\
\hline 130. & 30 & 550 & 160,83 \\
\hline 131. & 35 & 850 & 160,9 \\
\hline 132. & 20 & 640 & 160,8 \\
\hline 132. & 20 & 680 & 160,7 \\
\hline 134. & 20 & 610 & 160,58 \\
\hline 135. & 20 & 600 & 161 \\
\hline 136. & 120 & 1280 & 161 \\
\hline 137. & 25 & 700 & 160,95 \\
\hline 138. & 40 & 770 & 160,42 \\
\hline 139. & 20 & 480 & 160,42 \\
\hline
\end{tabular}




\begin{tabular}{|c|c|c|c|}
\hline szám & magasság $(\mathrm{cm})$ & átmérö $(\mathrm{cm})$ & szint (m) \\
\hline 140. & 15 & 530 & 160,4 \\
\hline 141. & 50 & 1080 & 160,78 \\
\hline 142. & 60 & 1110 & 160,6 \\
\hline 143. & 20 & 665 & 160,48 \\
\hline 144. & 40 & 1050 & 160,7 \\
\hline 145. & 50 & 1040 & 160,1 \\
\hline 146. & 30 & 738 & 160,1 \\
\hline 147. & 40 & 757 & 160,32 \\
\hline 148. & 20 & 697 & 160,32 \\
\hline 149. & 30 & 878 & 160,2 \\
\hline 150. & 80 & 1180 & 160,43 \\
\hline 151. & 30 & 680 & 160,33 \\
\hline 152. & 30 & 695 & 160,01 \\
\hline 153. & 35 & 570 & 159,88 \\
\hline 154. & 45 & 785 & 160,05 \\
\hline 155. & 40 & 823 & 159,75 \\
\hline 156. & 75 & 1145 & 160,17 \\
\hline 157. & 80 & 1085 & 160,22 \\
\hline 158. & 70 & 930 & 160,04 \\
\hline 159. & 80 & 1165 & 160,37 \\
\hline 160. & 70 & 930 & 160,04 \\
\hline 161. & 60 & 965 & 159,97 \\
\hline 162. & 70 & 1128 & 160,5 \\
\hline 163. & 50 & 950 & 160,28 \\
\hline 164. & 70 & 995 & 160,63 \\
\hline 165. & 55 & 915 & 160,73 \\
\hline 166. & 35 & 727 & 160,33 \\
\hline 167. & 30 & 565 & 160,41 \\
\hline 168. & 30 & 648 & 160,41 \\
\hline 169. & 30 & 800 & 160,35 \\
\hline 170. & 35 & 846 & 160,45 \\
\hline 171. & 30 & 635 & 160,41 \\
\hline 172. & 60 & 1200 & 160,88 \\
\hline 173. & 60 & 965 & 160,63 \\
\hline 174. & 50 & 982 & 160,61 \\
\hline 175. & 50 & 915 & 160,48 \\
\hline 176. & 60 & 965 & 160,53 \\
\hline 177. & 20 & 610 & 160,48 \\
\hline 178. & 30 & 670 & 161,91 \\
\hline 179. & 40 & 830 & 162,23 \\
\hline 180. & 20 & 500 & 162,08 \\
\hline
\end{tabular}




\section{Roman Tumuli in County Somogy}

\section{GÁBOR CSIZMADIA \& PÉTER GERGELY NÉMETH}

Besides introducing the Roman Age barrow cemeteries, this study also presents other burial locations of similar type with Prehistoric or uncertain dating, as well as the results of exploration of settlements near the Roman tumuli. We had the opportunity to excavate only two Roman barrows in Somogyaszaló (1996) and Somogyjád (1997-989) each. In 2007 three tumuli in Somogyvár-Bréza-erdő were probed. The Roman Age dating of the barrow fields in Orci and IregszemcseCsehipuszta (the latter one has been destroyed since) is based on earlier excavations. The dating of the barrows in Alsóbogát is supported with a great number of stray finds, while the location of the tumuli of Nagyberki - probably secondary burials in Early Iron Age mounds - is unknown. Roman Age mound burials appear in County Somogy at the turn of the 1 st and 2 nd centuries, and continue in the $2 \mathrm{nd}$ and $3 \mathrm{~d}$ centuries. The latest burial was found in Tumulus 1 in Somogyjád, dated to the last third of the $3 \mathrm{~d}$ century. New excavations would certainly be necessary to gain a more accurate view. Earlier measurements, too, badly need re-calibration by exploiting the advantages of digital technology. Surveys should also be extended to Prehistoric barrow fields. Uncertain dating of some locations must be clarified with excavations. 